4 nordon 



\section{Uppsamling och hantering av farligt avfall vid småvarv i Norden}

Knut Forberg och Anita Evenset 
Uppsamling och hantering av farligt avfall vid småvarv i Norden

TemaNord 2010:505

(c) Nordiska ministerrådet, Köpenhamn 2010

ISBN 978-92-893-2018-4

Publikationen är tillgänglig som Print on Demand (PoD) och kan beställas på

www.norden.org/order. Fler publikationer finns på www.norden.org/publikationer

Nordiska ministerrådet

Store Strandstræde 18

DK-1255 Köpenhamn K

Telefon (+45) 33960200

Fax (+45) 33960202

www.norden.org

\section{Nordiska rådet}

Store Strandstræde 18

DK-1255 Köpenhamn K

Telefon (+45) 33960400

Fax (+45) 33111870

\section{Det nordiska samarbetet}

Det nordiska samarbetet är ett av världens mest omfattande regionala samarbeten. Det omfattar Danmark, Finland, Island, Norge och Sverige samt de självstyrande områdena Färöarna, Grönland och Åland.

Det nordiska samarbetet är politiskt, ekonomiskt och kulturellt förankrat och är en viktig partner i europeiskt och internationellt samarbete. Den nordiska gemenskapen arbetar för ett starkt Norden i ett starkt Europa.

Det nordiska samarbetet vill styrka nordiska och regionala intressen och värderingar i en global omvärld. Gemensamma värderingar länderna emellan bidrar till att stärka Nordens ställning som en av världens mest innovativa och konkurrenskraftiga regioner. 


\section{Innehållsförteckning}

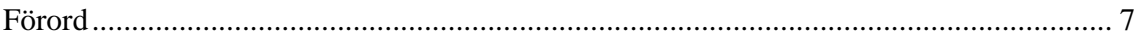

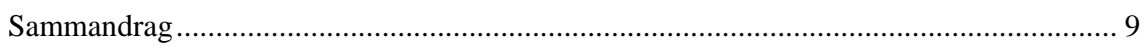

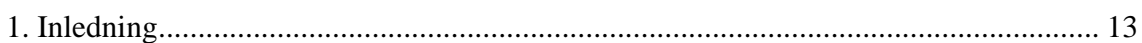

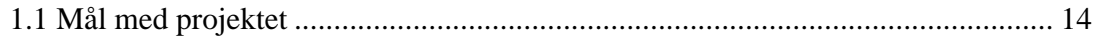

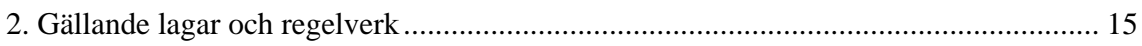

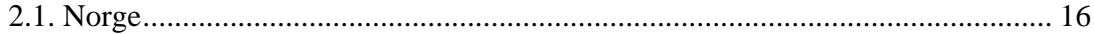

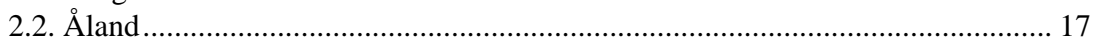

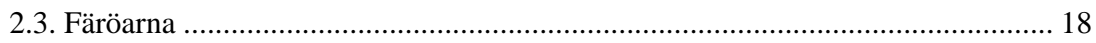

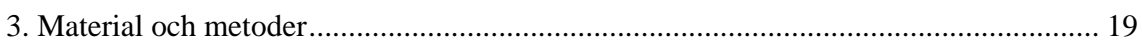

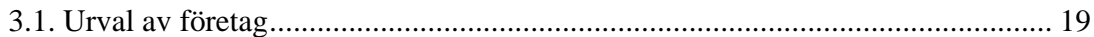

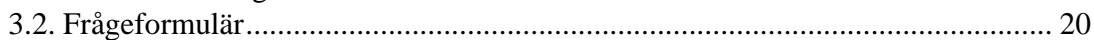

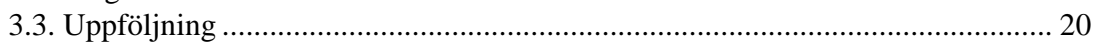

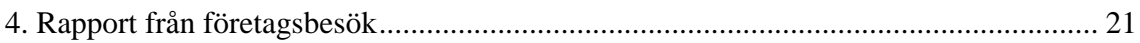

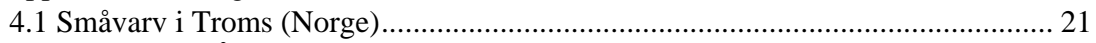

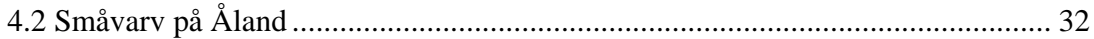

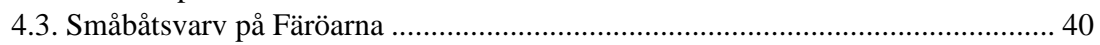

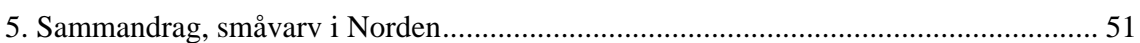

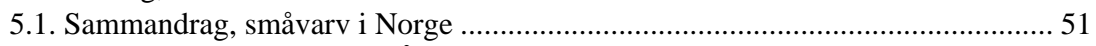

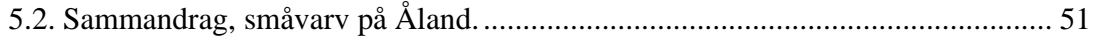

5.3. Sammandrag, små skeppsvarv på Färöarna .......................................................... 52

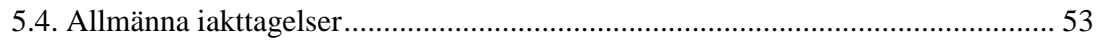

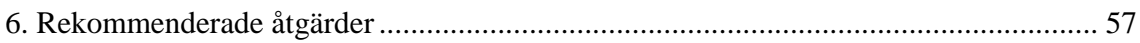

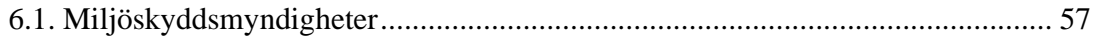

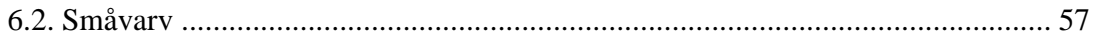

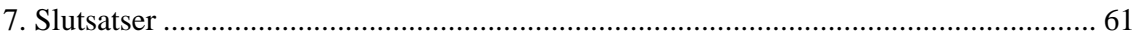

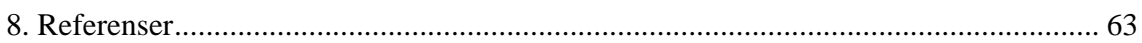

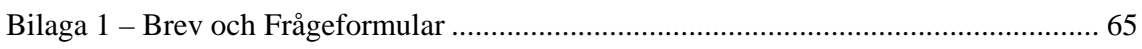

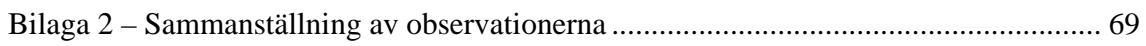





\section{Förord}

Det är väl känt att skeppsvarv bidrar till att förorena den marina miljön. Under senare år har nationella miljöskyddsmyndigheter satt ett ökat fokus på skeppsvarv, men har först och främst haft kapacitet till att följa upp varv av en särskild storlek. Hur och i hur stor grad varven har följts upp har dessutom varierat betydligt mellan de nordiska länderna. Gemensamt för dessa länder är att det finns en rad mindre varv längs kusten där man utför underhåll av båtar. Många av varven drivs som enmansföretag, medan andra sysselsätter mellan tre och tio anställda. Många drivs också som sidoverksamheter vid sidan av annat arbete. Dessa varv tillhandahåller i huvudsak sina tjänster till de minsta fartygen i kustfiskeflottan samt till fritidsbåtar.

Miljömyndigheterna har i liten grad följt upp verksamheten på den här typen av företag, och det var därför oklart hur situationen ser ut när det gäller miljömedvetande och miljöinsatser hos varvsägare. Det projekt som presenteras i denna rapport inleddes därför på initiativ av lokala miljöskyddsmyndigheter i Finnmark (Norge), på Färöarna och på Åland för att få ökade kunskaper om driften av samt rutinerna och inställningen hos småvarv. Projektet, som har finansierats av Nordiska ministerrådet, har genomförts av Akvaplan-niva AS. Varven som har ingått i undersökningen valdes ut i samarbete med miljöskyddsmyndigheter i Norge (Evy Jørgensen, fylkesmannen i Finnmark), på Färöarna (Suni Petersen, umhvørvisstovan) och på Åland (miljöskyddsinspektör Mia Westman från Ålands miljö- och hälsoskyddsmyndighet). Akvaplan-niva tackar alla representanter för ett bra samarbete under projektets gång. 



\section{Sammandrag}

Det är väl känt att skeppsvarv bidrar till att förorena den marina miljön. Skeppsvarv av en viss storlek har under senare år i olika grad följts upp genom kontroller och påbud från miljöskyddsmyndigheter i de nordiska länderna. Mindre varv, eller så kallade småvarv, som vanligtvis har mellan en och fem anställda, har endast följts upp i liten grad, och det råder därför osäkerhet om driftsformerna och miljömedvetandet på sådana små företag. Det projekt som presenteras i denna rapport inleddes därför på initiativ av lokala miljöskyddsmyndigheter i Finnmark (Norge), på Färöarna och på Åland för att skaffa information om driftsmodeller, befintliga kunskaper om och attityder till användning av miljöfarliga ämnen i samband med underhåll av båtar på så kallade småvarv i tre nordiska regioner: Troms län i Norge, Färöarna och Åland. Målgruppen har varit varv med mindre än fyra till fem anställda som sysslar med reparation och underhåll av båtar. Kartläggningen har i huvudsak genomförts genom besök på de företag som valdes ut i samarbete mellan Akvaplan-niva och lokala miljöskyddsmyndigheter.

Fyra små företag i Troms län, tre på Åland och tre på Färöarna (företagen på Färöarna var något större än de i Troms och på Åland) valdes ut som undersökningsmål för projektet.

De tre undersökta områdena har vitt skilda förutsättningar vad beträffar den omkringliggande miljön. Åland ligger i Östersjön, ett område som är starkt belastat av näringssalter och föroreningar, medan Troms län $\mathrm{i}$ Norge och Färöarna ligger i områden med bra vattenomsättning och lägre föroreningsnivå. Åland och Norge måste följa överordnade direktiv och regelverk från EU/EES, medan Färöarna står utanför EU och heller inte är anslutna till EES. Alla områden har nationella lagar och regler som måste följas av företag som släpper ut miljöskadliga föreningar. Till skillnad från Danmark och Sverige har inget av de undersökta områdena infört strängare nationella eller lokala regler för användning och deponering av ämnen.

Denna undersökning har genomförts på ett begränsat antal av de företag som sysslar med reparation och underhåll av båtar i de tre regioner som ingår i undersökningen. Det finns dock anledning att tro att den har fångat upp huvuddragen när det gäller vilken kunskapsnivå och inställning till miljövänlig drift som är representativ för undersökningsområdet. 


\section{Drift}

Vid besöken upptäcktes både bra och dåliga exempel på drift av småvarv i alla tre områden. Inget av de företag som besöktes hade fungerande rutiner för att kontrollera/rena spolvatten och avfall från rengöring och skrapning av båtar på land, även om ett företag hade inrättat en uppsamlingsbassäng för fast avfall från spolning. Ingen hade installationer för tvätt av båtbottnar i havet.

Hanteringen av avfall skedde på mycket olika sätt. En anläggning hade mycket bra rutiner för sortering/avhämtning av avfall, medan en annan anläggning inte hade några rutiner för detta över huvud taget. Andra företag hade system som delvis fungerade. Inga tydliga skillnader upptäcktes mellan de tre regionerna när det gällde driftsformer och rutiner.

\section{Kunskap}

Kunskaperna om de lagar och regler som gäller för företag som släpper ut miljöskadliga föreningar på land och i havet var bristfälliga hos de flesta av företagen. Ingen av de intervjuade företagsledarna/anställda hade kunskaper om vilka föreningar som användes i den egna driften som hade potentiellt skadliga effekter eller om vilka effekter utsläpp från fartygsunderhåll kan ha på marina organismer. Vår erfarenhet är att regelverket är svårtillgängligt för folk i allmänhet. Många företag ska förhålla sig till många olika internationella direktiv och nationella regler. En sammanfattning av relevanta regelverk (med hänsyn till olika aktiviteter, som luftutsläpp, havsutsläpp, avfallshantering med mera) för olika branscher kan förbättra tillgängligheten.

\section{Attityder}

De flesta intervjuobjekten tillkännagav att de ville driva verksamheten så miljövänligt som möjligt, inom vissa ekonomiska ramar. Kunskaperna om hur detta skulle uppnås var emellertid begränsade. Vår uppfattning är att många hade inställningen att kunskap ska "komma till dem av sig själv”, det vill säga att de lade över ansvaret för detta på miljöskyddsmyndigheterna. Få hade aktivt själva försökt att hålla sig uppdaterade. Även om kunskaperna om miljövänlig drift i allmänhet var begränsade fanns det exempel på verksamhetsägare som hade relativt goda kunskaper om och en positiv inställning till miljövänlig drift. Intervjuerna visade emellertid att kunskaper om och en positiv attityd till miljön inte nödvändigtvis utgör någon garanti för miljövänlig drift. 
Åtgärder

Både miljöskyddsmyndigheter och varvsägare kan vidta en del åtgärder som kan bidra till att förbättra driften vid småvarv. Miljöskyddsmyndigheterna kan bidra med att upprätta och distribuera information om lagar och regler, samt om vilka åtgärder som kan vidtas för att förbättra driften. De bör också inleda en dialog med småvarven för ett ömsesidigt informationsutbyte. Vidare bör man också sätta fokus på servicehamnar som inte traditionellt har slipar (vaggor på räls), men som har flyttbar lyftutrustning som gör att båtar enkelt kan lyftas och "parkeras" var som helst i terrängen. Det kan verka som om en viss kontroll, och eventuell certifiering, av företag som tillhandahåller service för småbåtar är ett nödvändigt verktyg för att höja standarden för miljövänlig drift av småvarv.

Företag som sysslar med reparation och underhåll av båtar bör själva se till att hålla sig uppdaterade på lagar och regler samt på vilka åtgärder som kan vidtas inom den egna verksamheten för att etablera rutiner och system för miljövänlig drift. Lokala miljöskyddsmyndigheter bör här bistå med hjälp med inhämtning av kunskap och vara en aktiv diskussionspartner.

Småvarv kan enkelt se till att inrätta system för sortering och hantering av farligt avfall. I alla de regioner som besöktes fanns det möjligheter för insamling av sådant avfall.

Enkla system för uppsamling av fasta ämnen från spolvatten bör inrättas på alla småvarv. Varv som hanterar många båtar per år bör dessutom inrätta system för rening av spolvatten. 



\section{Inledning}

Under de senaste åren har man dokumenterat att småbåtsvarvsverksamhet längs kusten har bidragit till att havssediment i hamnområden har blivit ordentligt förorenade. De största föroreningskomponenterna har visat sig vara polyaromatiska kolväten (PAH), tributyltenn (TBT), polyklorerade bifenyler (PCB) och enskilda tungmetaller (i huvudsak koppar $(\mathrm{Cu})$, zink (Zn) och bly (Pb)). Mest kunskap har man om utsläpp från större skeppsvarv, men det är också tydligt att mindre varv bidrar till att förorena den marina miljön.

Längs kustlinjen i samtliga av de nordiska länderna finns det småvarv, ofta kombinerade med småbåtshamnar och/eller mekaniska verkstäder. Detta är företag som tillhandahåller service åt den minsta kustfiskeflottan, samt en del fritidsbåtar. För att utföra underhåll under vattenlinjen är det nödvändigt med upptag av båtarna. Underhåll som vanligtvis utförs på småvarv är avlägsnande av beväxning (havstulpaner, blåmusslor, alger) och påföring av bottenfärg som innehåller medel som motverkar beväxning (antifouling). Enskilda firmor utför också enklare mekaniskt underhåll och reparationer. De flesta småvarv använder sig av båtvaggor på räls för upptag av båtar. Ett traditionellt småbåtsvarv har ett fåtal rälsgående vaggor för upptag av båtar, vilket klart begränsar antalet båtar per tidsenhet, och därmed kapaciteten och risken för att förorena miljön. Slipen är vanligtvis placerad direkt i vattenbrynet, så att allt som avlägsnas från båtarna genom skrapning och högtryckspolning hamnar direkt i strandzonen och därefter ut i havet (genom högvatten eller utspolning). Småvarv hittar man i dag främst i glesbygden. Mer centralt hittar man småbåtshamnar, ofta med möjligheter till upptag och underhåll på platser som traditionellt inte kallas för slip eller varv.

En "marina”, eller båthamn, disponerar ofta över stora uppställningsplatser, där det enkelt finns möjlighet att utöka utrymmet, och kan ta upp och transportera ett stort antal båtar med hjälp av truckar och kranar. Med stora kranar och truckar hanterar dessa många båtar per tidsenhet, och ofta lika stora båtar som de traditionella småvarven. Marinorna erbjuder ofta främst upptag och förvaring, och dessutom tillhandahålls mekanisk service och försäljning av produkter för underhåll av båtar. En stor del av underhållsarbetet, både båtputs och mekaniskt arbete, står båtägaren själv för. Denna organisation av arbetet innebär en stor utmaning när det gäller miljövänligt beteende i samband med båtinnehav. Enligt lag är båtägaren ansvarig för eget avfall/egna utsläpp, men samtidigt sker arbetet på företagets område, och företaget är efter allt att döma ansvarigt för de föroreningar som blir kvar på området. 
Strängare krav på uppsamling kommer innebära att många varv måste genomföra betydande ombyggnader. I många fall kommer detta att innebära stora investeringar. Enskilda större skeppsvarv kommer att klara av sådana kostnader, medan en del mindre verksamheter inte kommer att kunna täcka in detta på grund av begränsade inkomster. Utmaningen för mindre företag kommer alltså att vara att hitta rimliga tekniska och praktiska lösningar för uppsamling som fungerar tillfredsställande. Tidigare erfarenheter har dessutom visat att många varvsägare/anställda inte är medvetna om att de faktiskt hanterar miljöskadliga ämnen i sin verksamhet och att de genom sitt beteende bidrar till att förorena den marina miljön.

\subsection{Mål med projektet}

Målet med projektet som beskrivs i denna rapport har varit att skaffa information om driftsmodeller, befintliga kunskaper om och attityder till användning av miljöfarliga ämnen i samband med underhåll av båtar på så kallade småvarv i tre nordiska regioner: Troms län i Norge, Färöarna och Åland.

Det ligger på företagets ägare att sätta sig in i lagar och regler som gäller för verksamheten, men det är osäkert om detta praktiseras av den här typen av företag. En kartläggning av kunskapsstatusen när det gäller gällande lagar och regler togs därför med som en del av projektet.

Uppgifter om driftsformer, kunskapsstatus och inställning hos chefer och anställda på småvarv är viktigt för miljöskyddsmyndigheterna i arbetet med att förbättra miljöstatusen längs kusten. Ett annat mål har varit att ge de berörda företagen information som de kan använda för att förbättra sina driftsrutiner och eventuellt för enkla åtgärder som kan minska utsläppen och förbättra hanteringen av farligt avfall. Målgruppen har varit varv med mindre än fyra till fem anställda som sysslar med reparation och underhåll av båtar. Fokus för det här projektet var småvarv, men vi valde att även inkludera en marina med slipverksamhet i studien för att illustrera en lite annan typ av verksamhet som också bidrar med föroreningar.

Kartläggningen har huvudsakligen gjorts genom besök på de utvalda företagen. 


\section{Gällande lagar och regelverk}

De olika nordiska länderna har egna lagar och regelverk som stora och små industriföretag måste förhålla sig till. Det finns emellertid också överordnade EU- och EES-bestämmelser som gäller för de nordiska länderna. Dessa bestämmelser innehåller slutliga mål som EU/EES vill uppnå, men det är upp till de enskilda länderna att hitta en väg till målet. Norge är anslutet till EES, och måste således följa direktiv därifrån, Åland måste förhålla sig till EU:s direktiv, medan Färöarna står utanför EU och heller inte omfattas av EES. Även om EU- och EES-direktiv styr de överordnade principerna för miljöförvaltning står det de enskilda länderna fritt att sätta upp strängare regler än de som är fastställda enligt dem. Varken Norge, Åland eller Färöarna har vidtagit strängare åtgärder än de som är fastställda enligt EU/EES-bestämmelserna.

Det finns en rad bestämmelser och direktiv som är relevanta för driften av småvarv. Rådets direktiv 76/464/EEG från EES om att på ett samordnat sätt förebygga och begränsa föroreningar gäller i lika hög grad i alla EES-medlemsländer. Direktivet gäller "föroreningar orsakade av vissa farliga ämnen utsläppta i gemenskapens marina miljö”. Enligt direktivet får inga nya produkter för båtrengöring/underhåll användas utan att de är godkända.

Direktivet innehåller två förteckningar över ämnen: förteckning I, med översikt över vissa ämnen som valts ut främst med beaktande av deras giftighet, svårnedbrytbarhet och bioackumulering (inte ämnen som är biologiskt oskadliga eller som snabbt omvandlas till biologiskt oskadliga ämnen), samt förteckning II, med en översikt över ämnen som har en skadlig inverkan på vattenmiljön, men vars inverkan kan begränsas till ett givet område och som beror på recipientens egenskaper och belägenhet. I förteckning I finns bland annat tennorganiska föreningar, som tidigare vanligen användes vid bottenbehandling av båtar, och som totalförbjudits från och med 1.1.2008. I förteckning II finns kopparföreningar, bly, tenn och biocider, ämnen som även fortsättningsvis kan användas som tillsatser i bottenfärg enligt EES-direktivet. Vid varje utsläpp av dessa ämnen ska det på förhand finnas ett tillstånd där utsläppskraven fastställs.

Enligt rådets direktiv 96/61 EG, IPPC-direktivet (direktiv om samordnade åtgärder för att förebygga och begränsa föroreningar) är den ansvariga för en verksamhet skyldig att använda "bästa tillgängliga teknik" (BAT - best available techniques) för sin verksamhet, och de utsläppsgränser som fastställs i ett tillstånd ska baseras på BAT. Det är alltså upp till miljöskyddsmyndigheterna att se till att tillstånd endast beviljas under förutsättning att BAT följs. 
REACH (Registration, Evaluation and Authorisation of Chemicals) är EU:s nya regelverk som ska säkerställa en stärkt kemikalieförvaltning i Europa. REACH ersätter delar av det nationella kemikalieregelverket och får betydelse för en stor del av näringslivet, från större kemikalieindustri till mindre verksamheter som producerar, importerar, använder eller distribuerar kemikalier eller fasta bearbetade produkter.

Ramdirektivet för vatten (Vattendirektivet) är ett annat direktiv som kan inverka på praxis hos företag som släpper ut miljöskadliga ämnen. Det huvudsakliga målet med vattendirektivet är att säkerställa en god miljöstatus (nästan i naturligt tillstånd) i vatten, både vattendrag, grundvatten och kustvatten. Vattendirektivet trädde i kraft för medlemsstaterna den 22/12-2000, och infölivades i EES-avtalet år 2008. Statusen mäts med utgångspunkt i såväl ekologiska och hydromorfologiska som kemiska förhållanden. Om det visar sig vara tekniskt omöjligt att uppfylla målet om "god status", eller om det medför orimligt stora kostnader, ger direktivet möjlighet att senarelägga uppfyllandet av målet eller sätta upp mindre ambitösa miljömål. Direktivet ställer också krav på att man vidtar åtgärder mot förorening av vatten $\mathrm{i}$ enlighet med en förteckning över prioriterade kemiska ämnen som är särskilt farliga för livet i vattnet. Som en del av uppföljningen av direktivet kommer nya klassificeringssystem för miljöstatus att upprättas som ska gälla för alla EU-/EES-länder.

\subsection{Norge}

I Norge gäller lagen om föroreningar och avfall (forurensningsloven) de flesta föroreningskällor, med undantag av transportsektorn. Föroreningslagen fastslår att ingen har rätt att förorena utan att ha fătt tillstånd till det. Sådana tillstånd för enskilda verksamheter och enligt vissa villkor beviljas enligt lagens $11 \S$ och i enlighet med olika bestämmelser om förorenande verksamheter. Föroreningslagens $28 \S$ innefattar vidare förbud mot nedskräpning. Föroreningslagens kapitel 8, som trädde i kraft den 1/81989, innefattar regler om förorenarnas ersättningsansvar. I 55 § faststlås bland annat att förorenaren är ersättningsansvarig för föroreningsskada utan hänsyn till egen skuld.

Föroreningslagen administreras av Miljøverndepartementet (miljöskyddsdepartementet). Ansökningar om utsläppstillstånd för industriverksamhet och dylikt ska skickas till SFT, eller till fylkesmannens miljöskyddsavdelning för verksamheter som de är föroreningsmyndighet för.

På webbplatsen www.regelhjelp.no, som är en vägledning till regelverk relevanta för olika företag, finns det förenklade utdrag ur/ förklaringar till föroreningslagen. Webbplatsen kan vara till nytta för mindre företag som har behov av att sätta sig in i gällande lagar och regler för den egna verksamheten. 
I och med införandet av den så kallade Industriforskriften (industriförordningen) i Norge kommer kraven på slipar och skeppsvarv att skärpas. Dessa bestämmelser ställer standardkrav på företag utifrån deras storlek. De största företagen kommer utöver detta att behöva få särskilda tillstånd. Krav kan ställas på uppsamling av spolvatten, förorenade vätskor och annat processavloppsvatten. Vid arbetsoperationer vid kajer kommer det att ställas krav på uppsamling av färgrester (vid skrapning), olja eller andra potentiellt miljöskadliga ämnen. Dessutom föreslår man krav på särskild aktsamhet vid blästring/högtryckspolning av ytor som påförts antifouling/medel som motverkar beväxning.

Statens Forurensningstilsyn (statliga föroreningstillsynsmyndigheten) föreslår att om det finns en risk för att ytbehandling i havet kan medföra utsläpp av miljögifter, ska båtarna tas in i varven för blästring, och att ytbehandling i havet i sådana fall förbjuds. Blästring görs i liten utsträckning på småvarv och dessa bestämmelser kommer därför att vara mest relevanta för större varv.

När det gäller hantering av farligt avfall måste FOR 2004-06-01 nr 930: Forskrift om gjenvinning og behandling av avfall (avfallsförordningen) följas.

\section{2. Åland}

Viktiga regelverk på Åland i vilka det finns bestämmelser som är av betydelse för varvsindustrin är Miljöskyddslagstiftningen (implementering av IPPCdirektivet) och Renhållningslagen (ÅFS 1981:3) (www.regeringen.ax/ socialomiljo/miljo/lagstiftning.pbs).

I Ålands författningssamling, $2003 \mathrm{Nr} 58$ om mottagning i hamn av fartygsgenererat avfall och lastrester och i Landskapsförordning $\mathrm{Nr} 67$ om mottagning av fartygsgenererat avfall och lastrester regleras båthamnars ansvar för att sörja för mottagande av avfall från fartyg. Avfall till följd av rengöring av skrov (rester av bottenfärger) omfattas inte av denna reglering.

I Miljöhandlingsprogram för Åland 2005-2008 från den lokala regeringen berörs problemet med giftiga bottenfärger för båtar endast i den mån att huvudproblemet med den marina miljön verkar vara övergödning på grund av utsläpp av fosfat (P)- och kväve (N)-haltigt avfallsvatten.

Finlands miljöcentral (SYKE) reglerar användningen av medel som motverkar beväxning i Finland. De har utarbetat förteckningar över medel (och aktiva substanser) som det är förbjudet att använda, medel som är godkända för alla och medel som bara kan användas av kommersiella fartyg. 


\subsection{Färöarna}

I Lagtingslagen nummer 134 från den 29.10.1988 (Løgtingslóg nr. 134 frá 29. oktober 1988 um umhvørvisvernd/miljöskydd), finns det ett nationellt regelverk som omfattar förhållanden kring hantering av farligt avfall i samband med upptag, underhåll och reparation av mindre fartyg.

I kapitel 4, paragraf 15 står följande:

”Inget som kan förorena vattnet får tillföras älvar, vattenlopp, sjöar, kuster eller färöiskt havsterritorium eller anläggas så nära dessa att det kan finnas en risk för att det sköljs ut i vattnet. Enligt $\S 16$ kan dock tillstånd beviljas för att släppa ut spillvatten i vattendrag, sjöar, kuster eller färöiskt havsterritorium.”

I kapitel 5, paragraf 15 står följande:

\footnotetext{
"Verksamheter, anläggningar eller inrättningar som finns angivna i bilagan till lagen får inte anläggas eller startas innan dess att godkännande härom har tillkännagivits. De nämnda verksamheterna, anläggningarna eller inrättningarna får inte utvidgas eller ändras byggnadsmässigt eller driftsmässigt på ett sätt som påverkar verksamhetens föroreningsförhållanden innan dess att utvidgningen eller ändringen har godkänts.”
}

Lagen gäller bland annat verksamheter som utför ytbehandling av material av järn, stål eller metall, samt stålskeppsvarv och flytdockor.

Dessutom finns det en kungörelse om deponering av avfall som är relevant för små skeppsvarv - på färöiska: Kunngerð nr. 147 frá 19. oktober 1995 um burturkast, sum broytt við kunngerð nr. 90 frá 28. september 2007. 


\section{Material och metoder}

\subsection{Urval av företag}

Valet av företag gjordes i samarbete med miljöskyddsmyndigheterna i Troms och Finnmark i Norge, samt miljöskyddsmyndigheterna på Färöarna och på Åland. Företagen var verksamheter som miljöskyddsmyndigheterna hade kännedom om via sin kontrollverksamhet, men som inte låg under regelmässiga kontroller eller tillsyn. Innan besöken genomfördes skickades skriftlig information ut elektroniskt och på papper till minst fem verksamheter i varje målområde.

Inget av de företag vi skickade ut information/förfrågan till svarade, och vi kontaktade därför samtliga aktuella varv genom en rundringning via telefon.Genom muntliga förfrågningar fick vi in uttömmande information, och kunde avtala om att få besöka företagen. Av de företag som såg ut att vara lämpliga för vår undersökning var det endast ett företag som direkt avböjde att samarbeta.

Efter att kontakten med företagen var etablerad blev det tydligt att flera varvsägare var skeptiska till att information om deras verksamhet skulle publiceras i en öppen rapport. För att säkerställa deras samarbetsvilja och öppenhet kom vi därför överens om en viss typ av anonymisering, och vi har i huvudsak låtit bli att ange namn på personer och platser i rapporten. Vi har dessutom gjort enkla manipulationer av fotografier för att inte avslöja någons identitet.

En summarisk översikt över de företag som ingick i projektet ges i Tabell 1. Översikt över företag som besöktes som en del av projektet.

Tabell 1. Översikt över företag som besöktes som en del av projektet.

\begin{tabular}{llrr}
\hline Plats & Kod & Antal anställda & Antal fartyg/år \\
\hline Troms, Norge & N 1 & 1 & 25 \\
Troms, Norge & N 2 & $4-5$ & 35 \\
Troms, Norge & N 3 & $3-5$ & 220 \\
Troms, Norge & N 4 & 1 & $?$ \\
Åland & $\AA 1$ & 1 & 20 \\
Åland & $\AA 2$ & 1 & 30 \\
Åland & $\AA 3$ & 1 & 200 \\
Färöarna & F 1 & 5 & $50-60$ \\
Färöarna & F 2 & 20 & $35-55$ \\
Färöarna & F 3 & 15 & $30-35$ \\
\hline
\end{tabular}




\subsection{Frågeformulär}

Före företagsbesöken utarbetades ett frågeformulär som sändes till företagen. Centrala frågor var verksamhetens omfattning, kunskap om miljöfarliga ämnen, utsläppsreducerende åtgärder, kännedom om och uppföljning av regelverket samt attityder till miljöfrågor. En kopia av frågeformuläret finns bifogad till rapporten (Bilaga 1). De flesta företagsinnehavarna hade läst igenom frågorna före företagsbesöket, men själva formuläret ifylldes i huvudsak i samarbete med representanten från Akvaplan-niva.

Utöver svaren på dessa frågor, utgjorde en inspektion och fotodokumentation en viktig del av projektarbetet.

Efter företagsbesöken sammanfattades och evaluerades informationen från frågeformulären. I nästa kapitel ges en sammanfattning från varje enskilt företagsbesök. Därefter sammanfattas och kommenteras allmänna intryck och observationer i det avslutande kapitlet.

\subsection{Uppföljning}

Rapporten från projektet kommer att sändas till företagen som besöktes och vi kommer också efteråt att kontakta dem per telefon för att undersöka om de har ytterligare frågor gällande möjligheter att genomföra åtgärder. 


\section{Rapport från företagsbesök}

\subsection{Småvarv i Troms (Norge)}

Troms län ligger i Nordnorge, mellan Nordlands län i söder och Finnmarks län i norr. Kustområdena karaktäriseras av starka tidsvattenströmmar och oftast av god omsättning av vattenmassorna. Inne i marinor/servicehamnar med uppläggning är vattenomsättningen dålig på grund av naturliga och konstgjorda avskärmningar för att ge lugna hamnförhållanden.

Det finns en utredning om förorening från småbåtshamnar i några län $\mathrm{i}$ Norge, men inte från Troms (SFT, 2005). Vidare har det gjorts en kartläggning av varv längs Norges kust (SFT, 2004). Dessa har gett nyttig bakgrundsinformation för den aktuella undersökningen.

Generellt är miljöförhållandena längs kusten i Troms goda, men höga koncentrationer av miljögifter har dokumenterats i flera hamnområden (exempelvis i Harstad och Tromsö), samt i några småbåtshamnar (exempelvis Mørck 2005; Evenset \& Palerud 2004; Evenset et al. 2005).

\subsubsection{Norska företaget N1}

Varvet, som är ett enmansföretag, ligger centralt placerat på en liten ort, något skyddad av en fiskebrygga i söder, och en pir, där det finns ett fiskförädlingsföretag, i norr (Figur 1). Detta är en typ av slip som finns, eller har funnits, i de flesta små samhällen längs kusten. Många står i dag overksamma, antingen på grund av utflyttning, eller för att funktionen har övertagits av flyttbara kranar och truckar. 


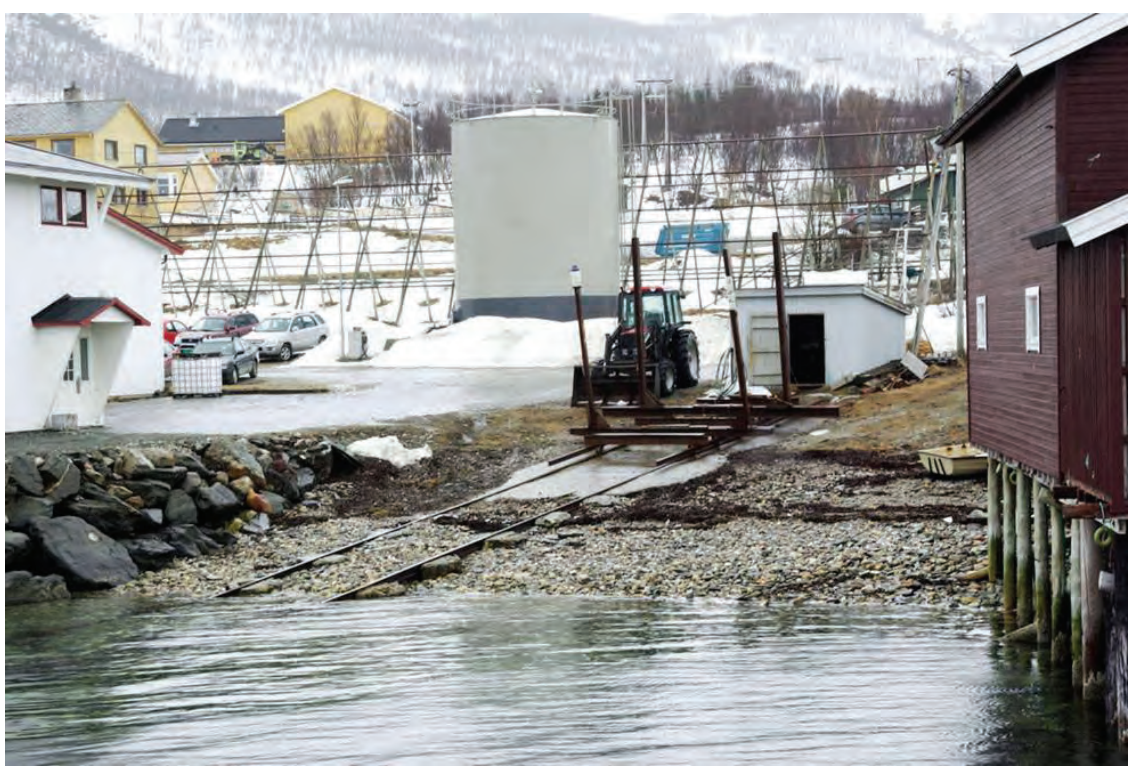

Figur1. Slipen ligger i lä mellan kajen i söder och piren i norr.

Slipen ligger på en sluttande strandbädd med små tångbevuxna stenar, i nedre delen av littoralzonen. Kustlinjen är i övrigt ganska rak och tidvattenströmmen längs strandkanten är relativt stark.

Systemet för upptagning är en rälsgående vagn (Figur 2). Vagnelementen består av H-balkar i olika dimensioner. Det finns fyra stöttepelare på sidorna som kan regleras efter båtarnas bredd. Den har ingen vagga, utan båtarna måste vila på egen köl under uppdragningen.

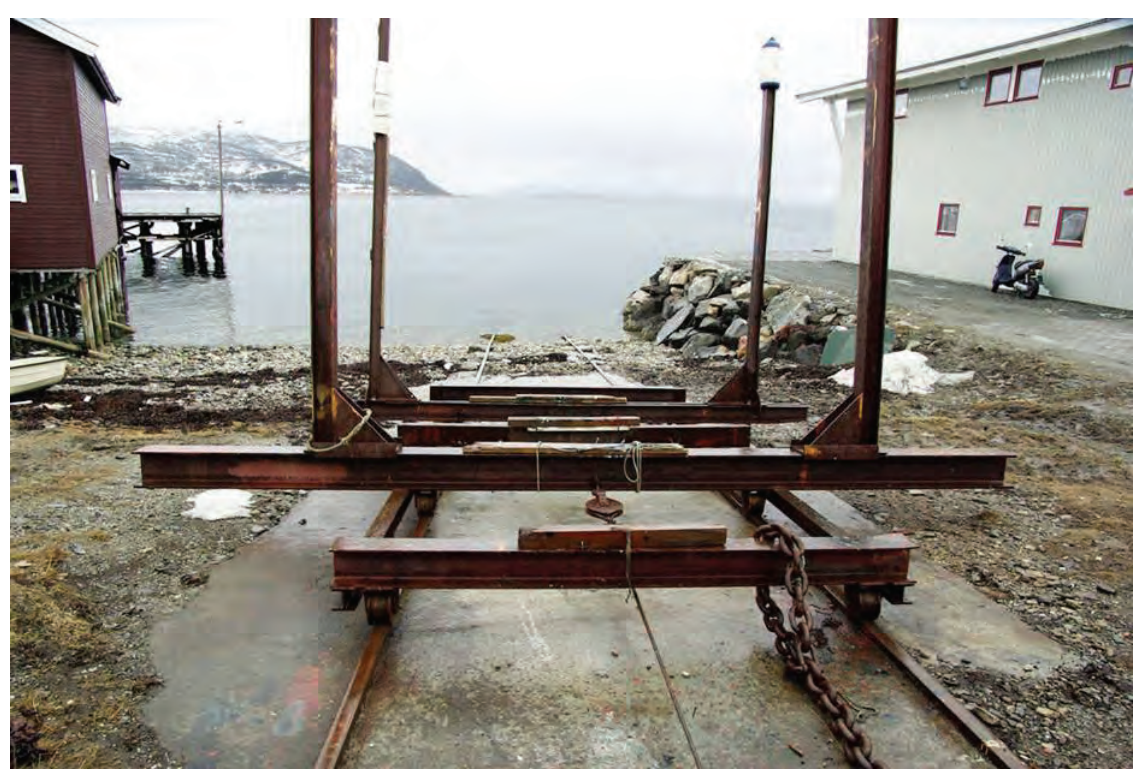

Figur2. Uppdragsvagn på räls, med flyttbara sidostöd.

Rälsens fundament utgörs av armerade betongelement som har grävts ned i strandbädden (Figur 3). Vagnen dras av en kraftig elmotor (Figur 4), 
som är placerad i ett litet hus precis ovanför tidsvattenzonen. Anläggningen har tillgång till el och vatten.

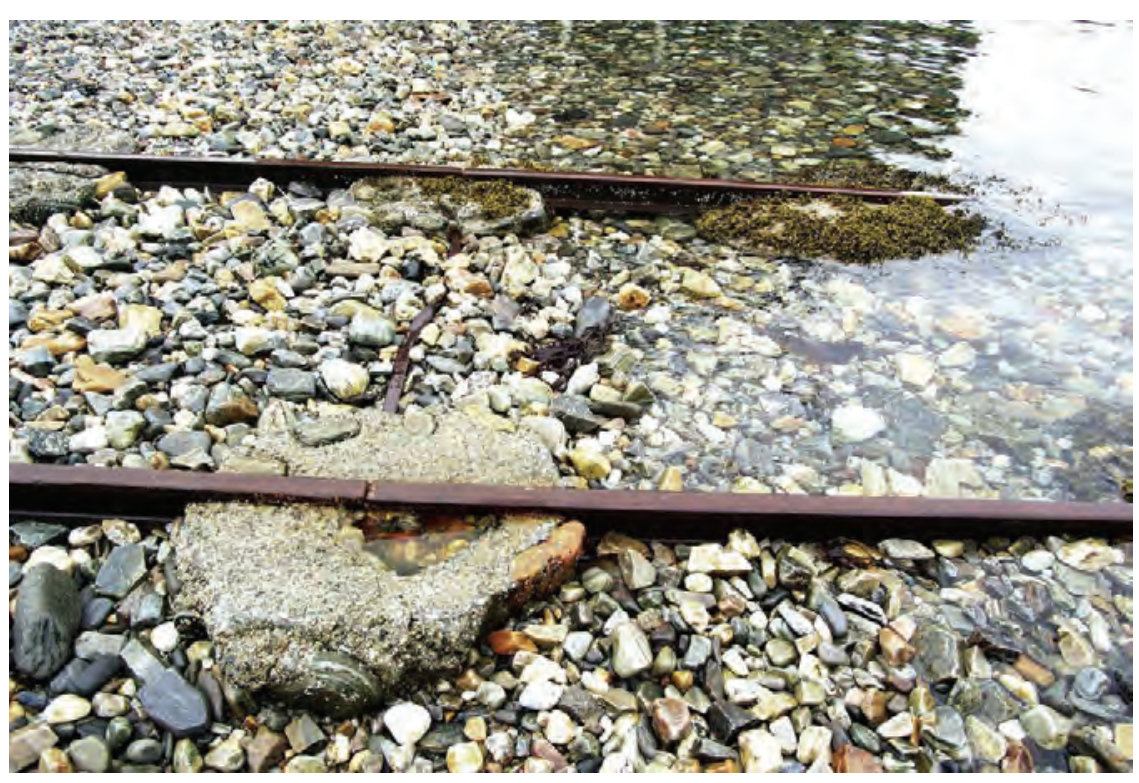

Figur3. Slipens räls är fäst vid marken med betong. Tångbevuxna stenar på strandbädden.

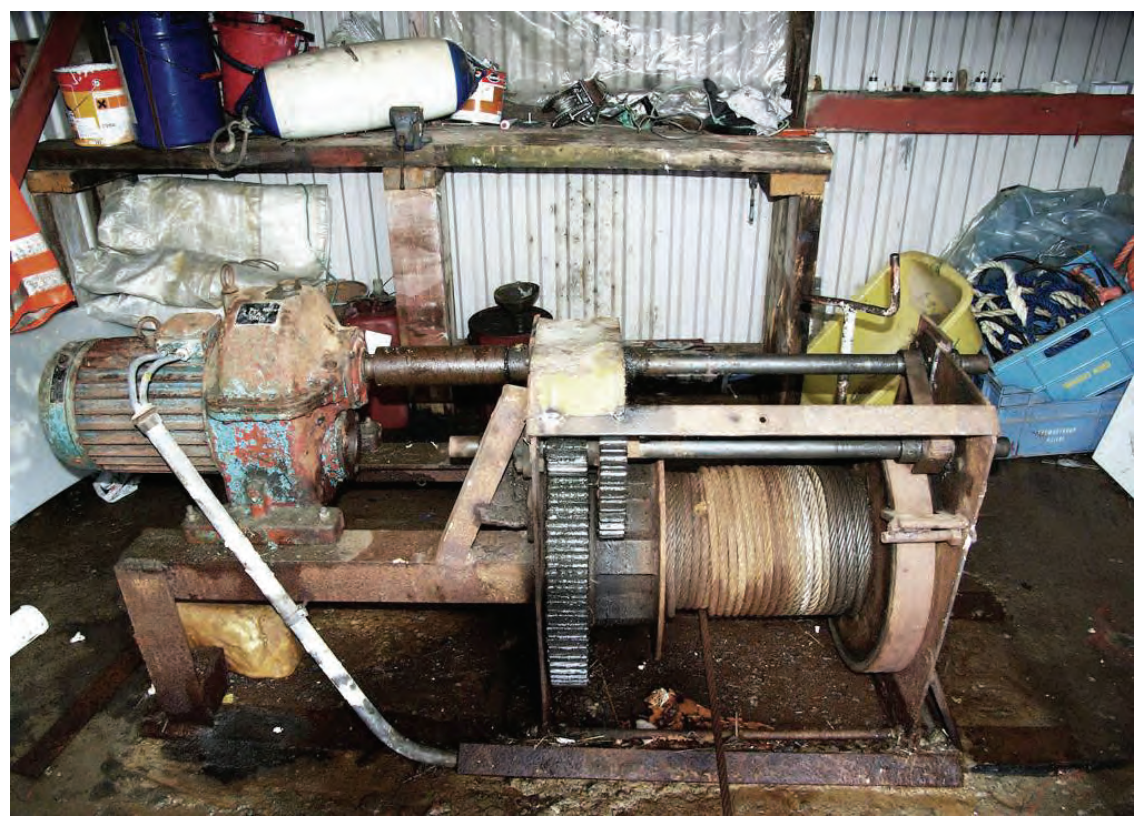

Figur 4. Vinsch med $15 \mathrm{~mm}$ vajer, driven av en elmotor.

Slipen byggdes cirka 1980 och har använts för lokala fiskebåtar i storleksklassen 20-35 fot. Omfånget på verksamheten har varit anspråkslöst: tidigare tog slipen upp omkring 25 båtar per år, medan antalet i dag ligger på cirka 10. Slipen har en potential gentemot fritidsbåtmarknaden, men antalet uppställningar är likväl begränsat eftersom det bara finns en vagn/en uppläggningsplats. 
Det fanns inget synligt avfall vid slipen eller i närområdet. Det fanns inte heller egna containrar för uppsamling av farligt avfall. Tidigare var en tank för uppsamling av spillolja utplacerad här, troligen från kommunens sida, men det fanns ingen sådan vid tidpunkten för besöket. Ägaren medgav att en tank borde komma på plats så snart som möjligt.

Vid en ytlig inspektion skilde sig det biologiska tillståndet på slipområdet inte från "outnyttjade" strandzoner i (obebyggt) närområde (bortsett från några fläckar av slutstrykningsfärg på betongfundamenten). Det växte brunalger och det fanns flerårig havstulpan (Balanus sp.) vid nedre delen av rälsen.

Enligt ägaren användes mycket ABC-bottenfärg (med koppartillsats) vid slipen. Ägaren hade begränsad kunskap om miljöskadliga ämnen och om vilka effekter dessa kan ha på den marina miljön. Han ansåg vidare att slipens verksamhet var så begränsad att eventuella skadeverkningar är försumbara. Hans kännedom om regelverk var begränsad och han hade inga planer på att inrätta system för uppsamling av spolvatten, färgrester och liknande.

\subsubsection{Norska företaget N2}

Företaget ligger i en liten bukt ett stycke ut i en öppen fjord. Företaget har inga grannar, varken privatpersoner eller andra företag (Figur 5). Det ligger en fiskodlingsanläggning cirka 2 km från varvet.

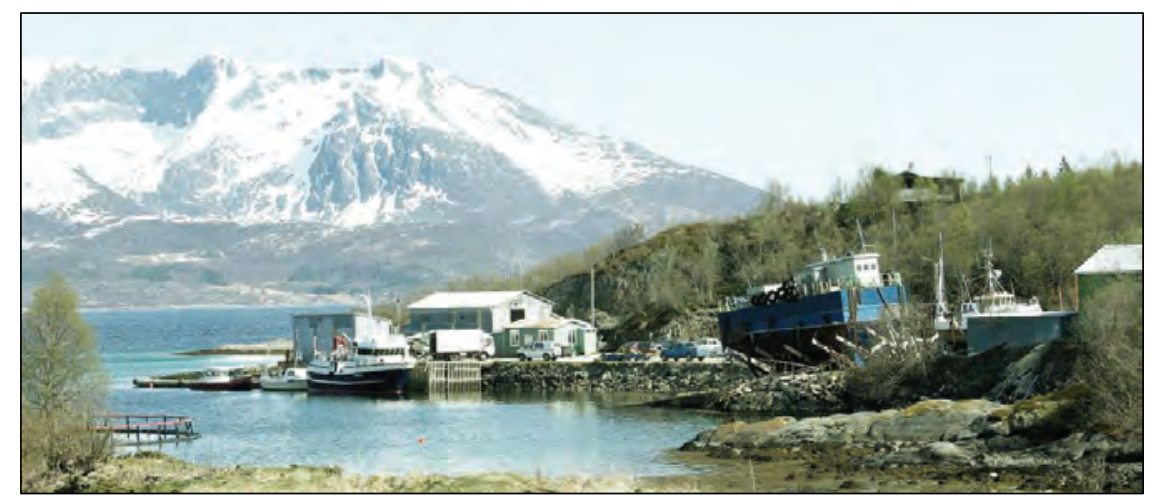

Figur 5. Varvet N2 ligger vid ett relativt öppet farvatten i ett glest befolkat område.

Varvet har 4-5 anställda och erbjuder i huvudsak mekaniska tjänster. De flesta båtar som tas upp på slipen spolas också med vatten (högtryckspolning) och målas med bottenfärg med pensel eller rulle. Detta arbete utförs i huvudsak av båtägarna och allra mest används självpolerande bottenfärg av märket Jotun Antifouling SeaQueen (Figur 6). Denna bottenfärg innehåller bland annat dikopparoxid och kadmium. 


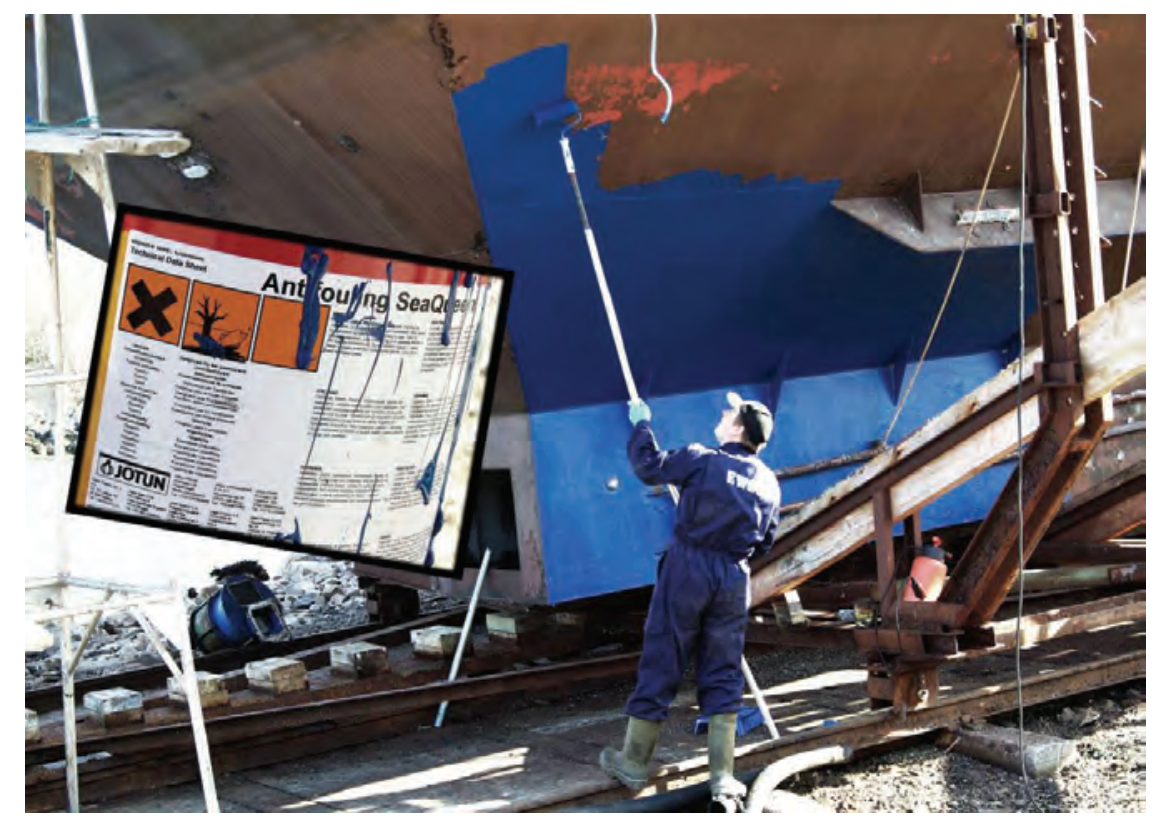

Figur 6. På varvet N2 utförs tvätt och bottenbehandling av båtägarna.

Strandbädden sluttar jämnt ned mot sublittoralzonen och substratet består av små stenar. I nedre delen av strandbädden växer det blåstång, och djurlivet karakteriseras av havstulpan (Balanus sp.) och blåmusslor (Mytiulus edulis) (Figur 7).

Ytligt betraktat var flora och fauna i stort sett lika på slipplattformarna och på de angränsande strandområdena.

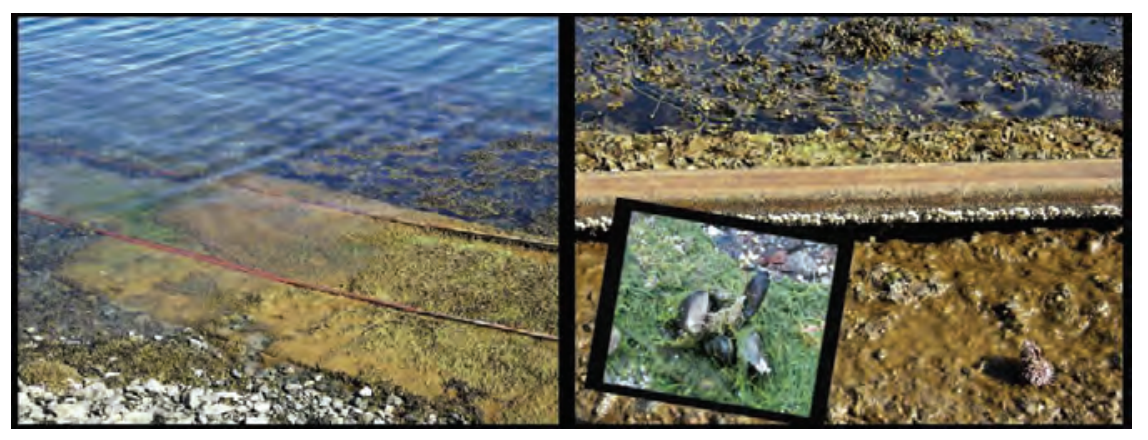

Figur 7. Vid slipen på företaget N2 växer flerårig havstulpan på rälsen och blåmusslor mellan rälsen.

Varvet har två rälsgående båtvaggor placerade på helgjuten betong. Den största vaggan kan ta båtar upp till 60 fot. Den nuvarande ägaren övertog varvet 2000 och ska då ha genomfört en omfattande uppstädning av avfall från området. Företaget tar upp cirka 10 båtar på 25-33 fot och 25 båtar på 33-50 fot årligen. De uppger att det går åt cirka 300 liter bottenfärg per år. Medan verksamheten tidigare baserade sig på fiskeflottan, är fiskodlingsnäringen numera den viktigaste kundkretsen. Företaget hade inga fritidsbåtsägare som kunder. 
Varvet har inga system för uppsamling av färgrester från spolning och målning av båtar, och har inte heller planer på att inrätta ett sådant system.

Kunskaperna om vilka ämnen som är förbjudna att använda vid bottenmålning var bristfälliga, och man litade på att den färg (Jotun) som köptes i Norge var tillåten. Kännedomen om regelverk för utsläpp i miljön var begränsad, liksom om varför det är förbjudet att använda vissa enskilda ämnen.

Varvet hade väl märkta containrar för uppsamling av metall, brännbart avfall, förorenat vatten (költvätt m.m., inte spolvatten), förorenad olja och för ren spillolja (Figur 8; Figur 9). För ren spillolja fick de betalt; de betalar för avhämtning av det övriga. Ett privat avfallsbolag (Perpetuum Holding AS) hämtar farligt avfall från varvet, medan det kommunala avfallsbolaget hämtar restavfallet.

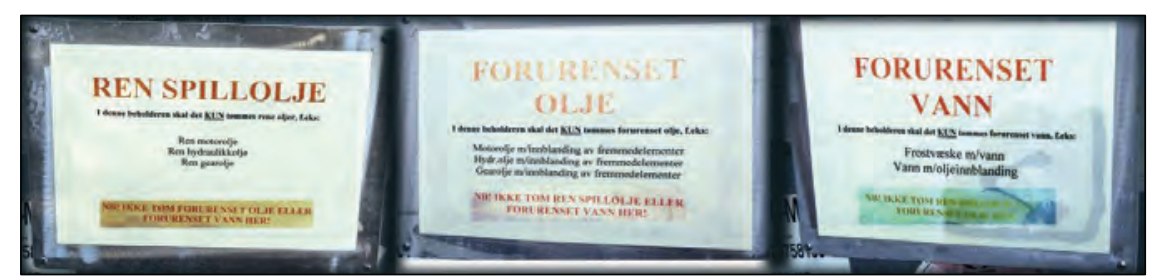

Figur 8. Märkning av avfallscontainrar för flytande avfall på varvet N2.

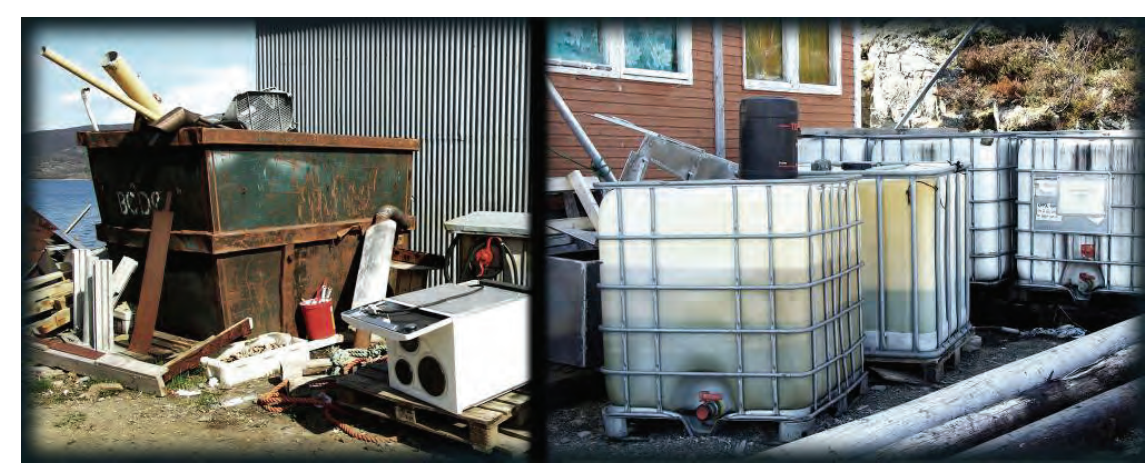

Figur 9. Avfallscontainrar för fast och flytande avfall på varvet N2.

Företagsinnehavaren anser att de har en bra dialog med länets miljömyndigheter, och säger att en stor del av driftsöverskottet går åt till att sköta driften av varvet på ett miljömässigt försvarbart sätt. Ägaren säger att en sådan prioritering kan vara en förklaring till att varvet har ett gammalt och slitet byggnadsbestånd.

\subsubsection{Norska företaget N3}

Företaget ligger längst inne i en småbåtshamn, som är inrättad med hjälp av en vågbrytare. Området har ganska starka strömmar, men vågbrytaren skyddar småbåtshamnen och också området där varvet ligger. Varvet ligger i ett industriområde och det finns olika företag i närområdet (Figur 10). Varvet drivs av ett båtcenter, där 3-5 personer arbetar med försälj- 
ning och underhåll av båtar. Verksamheten baserar sig i stor grad på uppdrag från fritidsbåtsägare, men också från fiskeflottan.

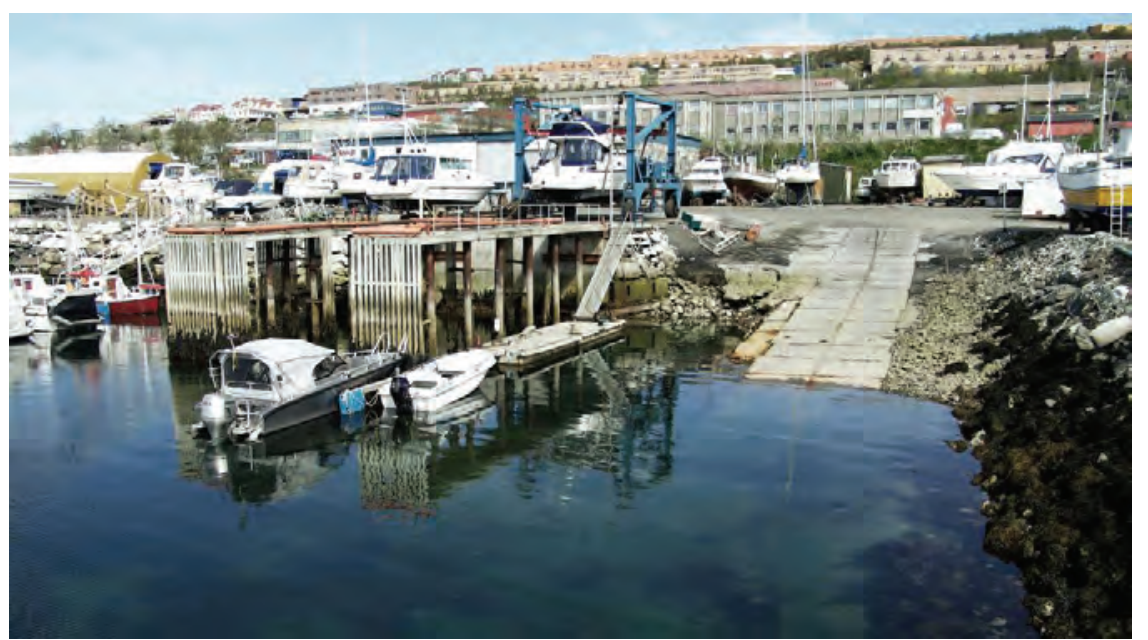

Figur 10. Varvet N3 har två system för att ta upp båtar: vagn med lyftstropp och plattform för uppdragning med en hjulgående vagga dragen av en hjullastare.

Varvet behandlar cirka 220 båtar om året, av vilka de flesta är i storleksklassen 20-35 fot. Ungefär 50 båtar är större än 35 fot (upp till 50 fot). De allra flesta av dessa högtryckspolas och målas med bottenfärg. Grundmålning med epoxibaserad tvåkomponentfärg förekommer, men i väldigt liten omfattning. Glasfiberarbeten och liknande görs i huvudsak inomhus under vintern.

Båtarna lyfts med hjälp av en mobil kran eller med en vagga på hjul över en sluttande betongplattform och högtryckspolningen kan utföras på en slänt täckt av betonghällar (Figur 11).

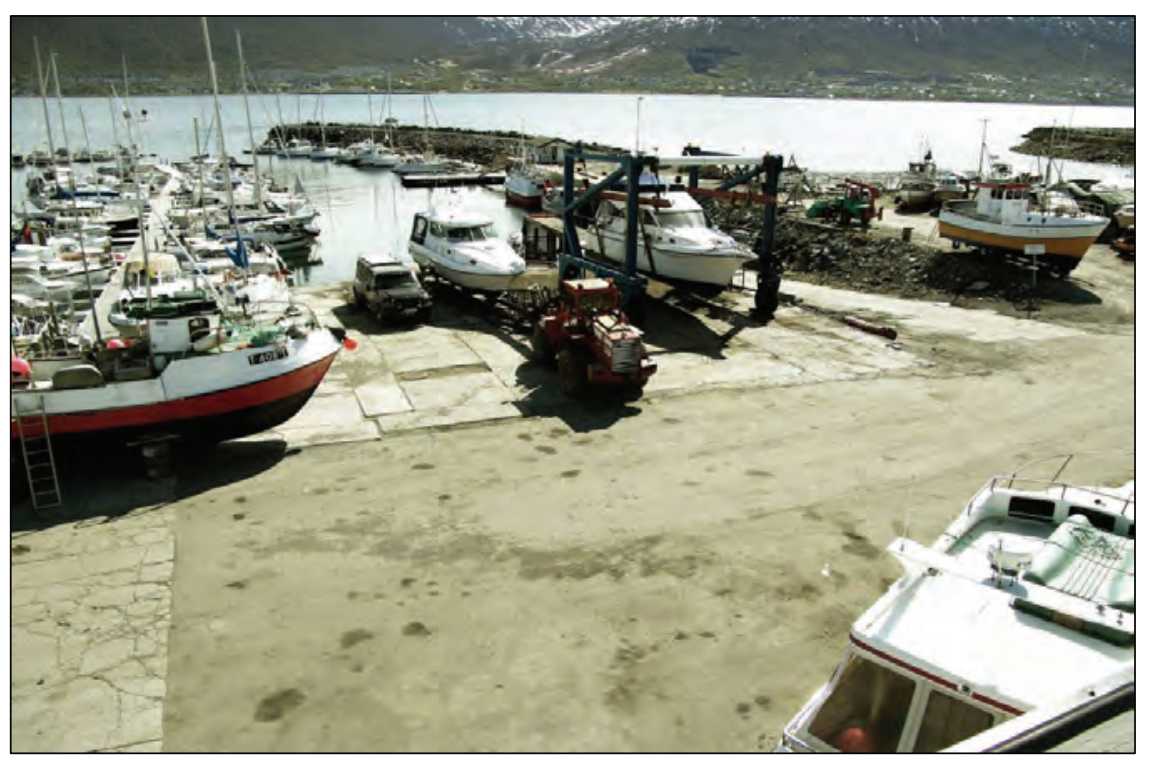

Figur 11. Översikt över uppläggning av båtar vid varvet N3. 
Varvet har en körbar vagga med lyftmekanism som kan placeras på betonghällarna. I den nedre kanten av betongplattan finns en sedimentationsbassäng (cirka $1 \times 1 \times 2,5 \mathrm{~m}$ ), där spolvatten och färgrester spolas ned (Figur 12).

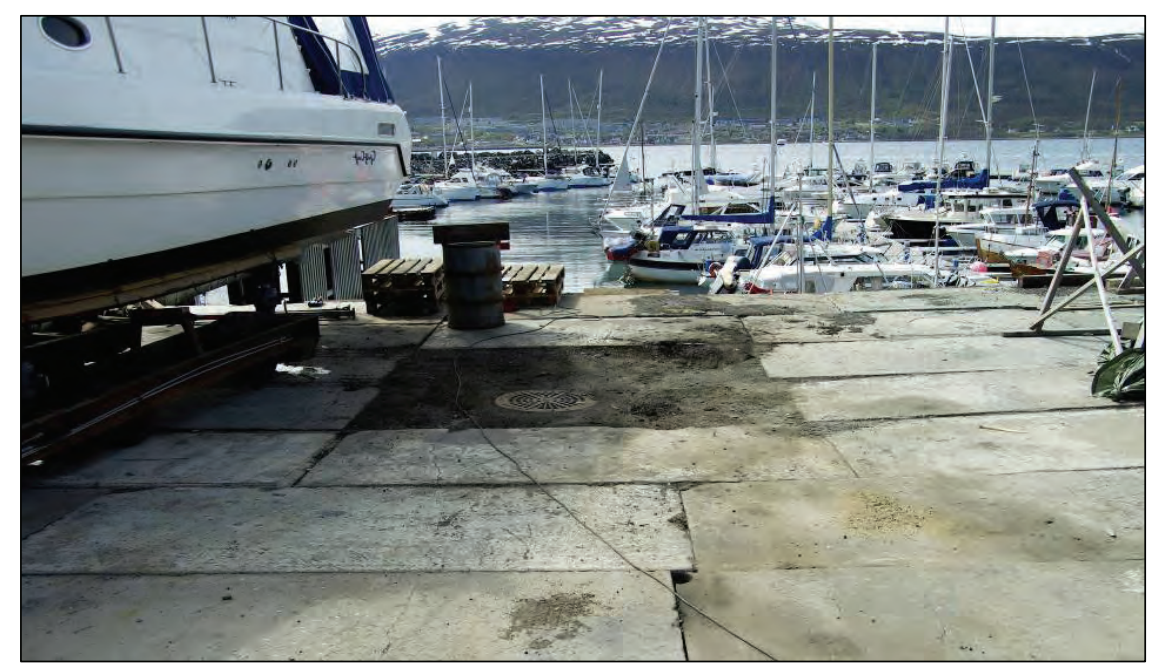

Figur 12. Gjutna betonghällar, sluttande mot uppsamlingsbassängen för spolvatten på varvet $N 3$.

Ägaren uppskattar att cirka 80 procent av spolvattnet samlas upp där, eftersom det är ett bra lut mot bassängen. Överloppsvattnet från bassängen leds direkt ut i recipienten. Enligt de anställda var sedimenteringen i bassängen relativt anspråkslös, och den hade aldrig tömts. Enligt företagets planer skulle sedimenterat material avhämtas som farligt avfall. Sedimentationsbassängen inrättades 2003, ungefär samtidigt som den nuvarande ägaren övertog varvet. Detta gjordes på eget initiativ. Företagets anställda var medvetna om miljöfrågor, och sade att de ville driva verksamheten så miljövänligt som möjligt utan att det medförde kostnader som företaget inte kunde klara av. De hade haft en positiv dialog med en representant från länsstyrelsens (Fylkesmannens) miljöskyddsavdelning när bassängen inrättades, men hade inte fått någon uppmaning att inrätta uppsamling. Kunskaperna om regelverk och vad de var förpliktade till enligt dem var bristfälliga. 


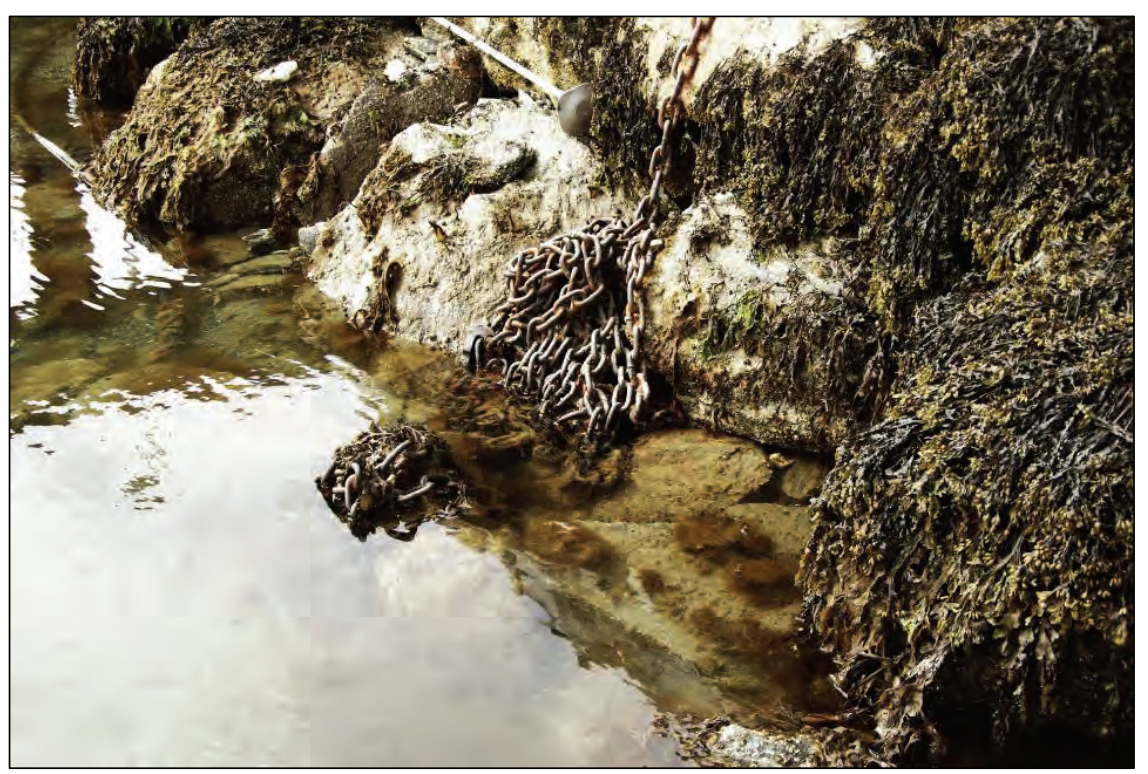

Figur 13. Tidvattenzonen under spolplattformen på varvet N3.

Plattan där spolning genomförs består som ovan nämnts av betonghällar. Mellan hällarna finns det smala sprickor (cirka 1-2 cm) där vatten kan tränga ner i marken. Ägarna påpekade själva detta problem och sade att de hade övervägt att gjuta en helgjuten platta, men de antog att en sådan skulle ha spruckit upp med tiden i alla fall på grund av tjälen och köldsprängning.

Bottenfärg stryks oftast på av båtägarna själva och bara i undantagsfall av företagets anställda. Företaget säljer bottenfärg, huvudsakligen av märket Hempel, som också företaget själv använder. Båtägarna använder flera olika typer av färg. Informationsblad om produkterna som företaget säljer och använder fanns tillgängliga. Varvets anställda använder omkring $50 \mathrm{l}$ bottenfärg om året. Till detta kommer bottenfärgen som båtägarna själva använder. Varvsägaren var medveten om att all spolning skulle ske på plattan ovanför sedimenteringsbassängen, men påstrykning av bottenfärg utfördes på flera andra uppläggningsplatser. Kunskaperna om vilka ämnen som är förbjudna att använda vid bottenmålning var bristfälliga, och man litade på att importörerna av bottenfärg och andra lösningsmedel har kännedom om reglerna och att bara tillåtna medel finns till salu. Kännedomen om regelverk för utsläpp i miljön var begränsad, liksom om varför det är förbjudet att använda vissa enskilda ämnen.

Som ovan nämnts ligger varvet innanför en småbåtshamn. Nedanför varvet har det byggts en mur ner mot tidvattenzonen. Det ligger ofta en tunn oljefilm på vattenytan innanför vågbrytaren, men den kommer sannolikt från en bränslepump som förser båthamnens båtar med diesel och bensin. Denna drivs inte av varvet. Stora stim av små fiskar observeras ofta på området. 
Varvet och den angränsande marinan hade väl märkta containrar för uppsamling av olika typer av farligt avfall. En container för restavfall var också placerad på området (Figur 14).

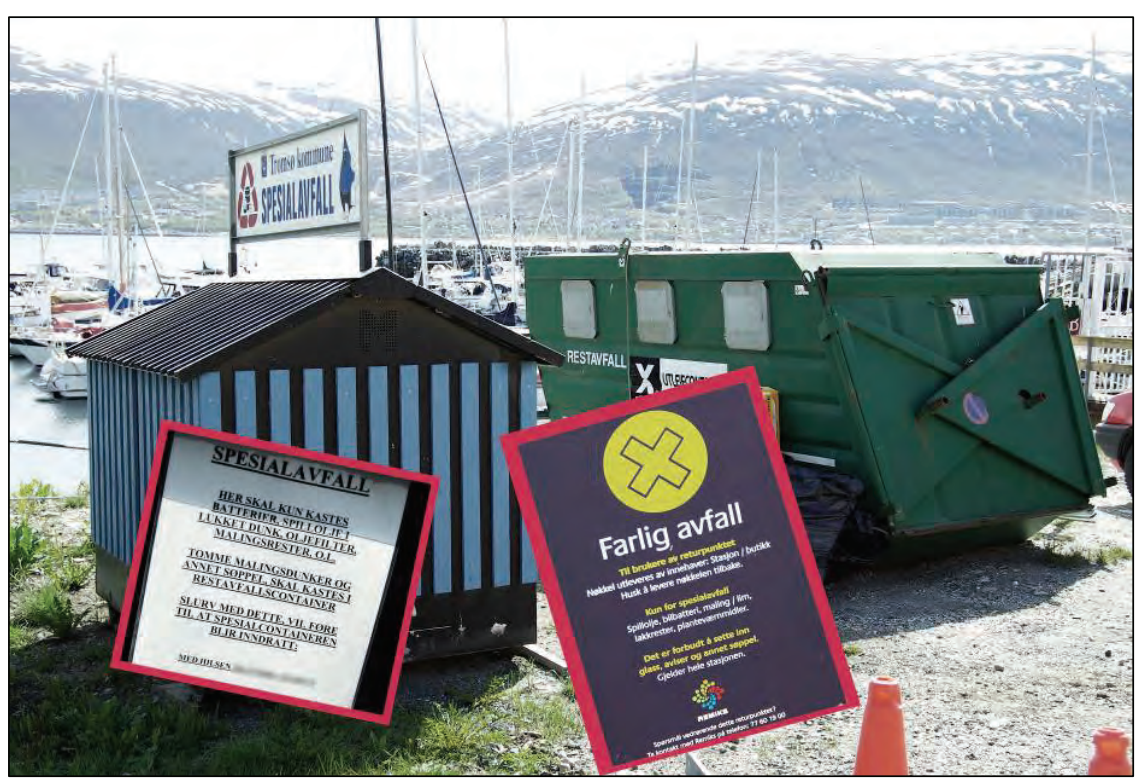

Figur 14. Väl märkta containrar för specialavfall och för restavfall på varvet N3.

Båtcentret och marinan uppgav att de ofta måste sortera avfall som var placerat i containern för restavfall för att båtägare lade farligt avfall i den. Det kommunala avfallsbolaget hämtar både restavfall och farligt avfall. Det var i stort sett välstädat på området. I början av 2000-talet blev den dåvarande ägaren ålagd att städa upp runt varvet, och att avlägsna oljeförorenad jord som låg på egendomen. Den nuvarande ägaren ville att tomten ska framstå som städad.

\subsubsection{Norska företaget $N 4$}

Vi gjorde ett kort besök på ett varv där ägaren inte hade möjlighet att ställa upp. Det var stor aktivitet på varvet (Figur 15). Den hade tre rälsgående båtvaggor och dessutom en hjullastare för flyttning av båtar på land. Varvet fungerade enligt "självbetjäningsprincipen" och båtägarna stod för all aktivitet vid tidpunkten för inspektionen. Det fanns inga synliga arrangemang för avlämning av avfall eller för uppsamling av spolvatten. Däremot fanns det mycket osorterat avfall i högar runt anläggningen (Figur 15), och det fanns öppna fat med spilloljeprodukter (Figur 17). 


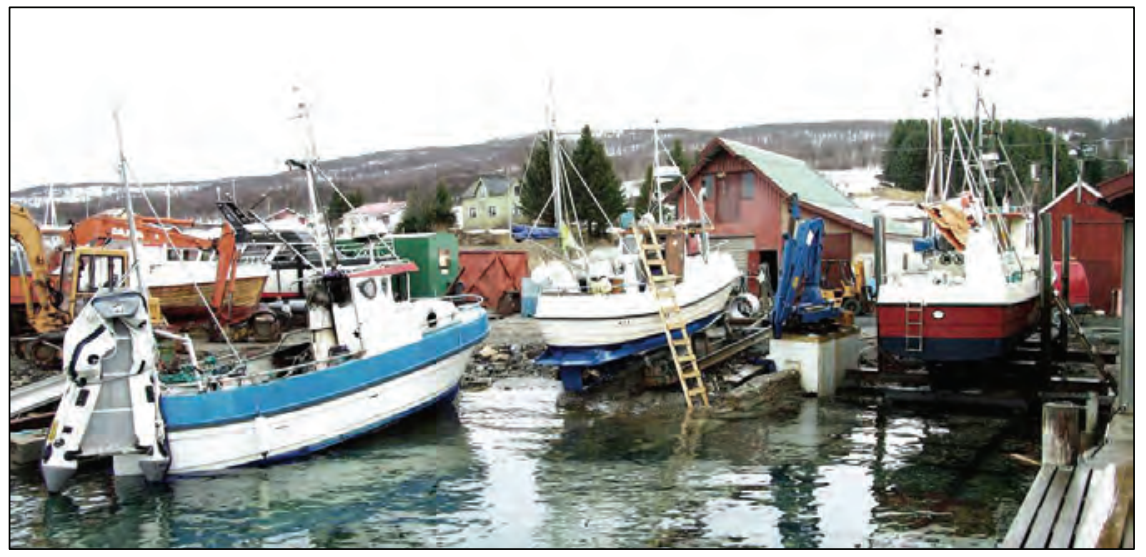

Figur 15. Stor aktivitet på varvet N4.

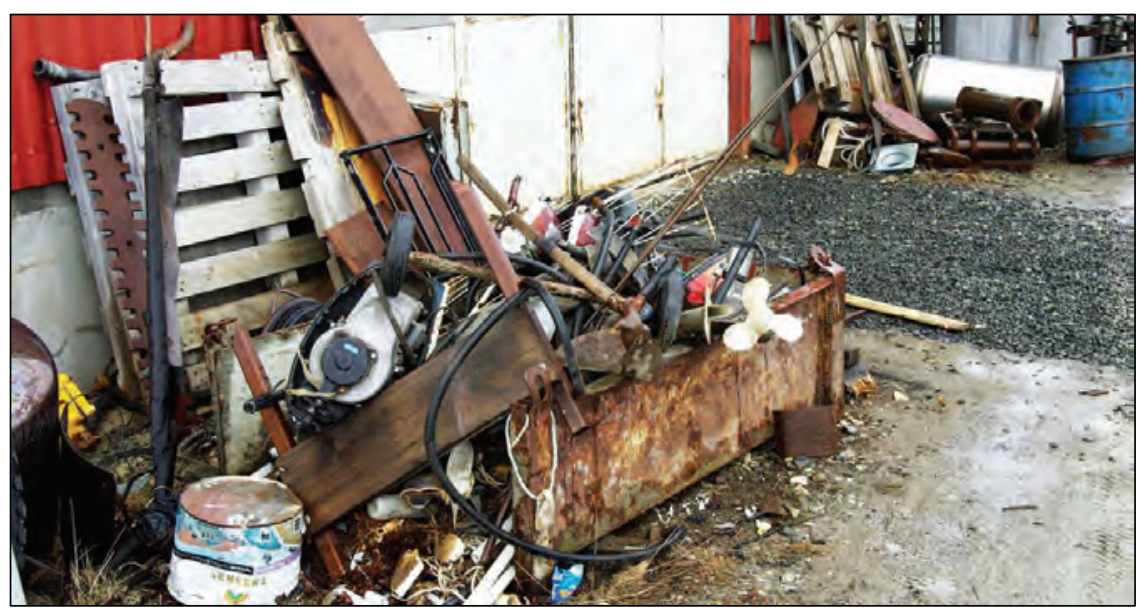

Figur 16. Exempel på hög av osorterat avfall vid varvet N4.

Varvets ägare hade varit i dialog med miljömyndigheterna, men hade dittills inte haft besök eller fått krav vad gäller varvets drift.

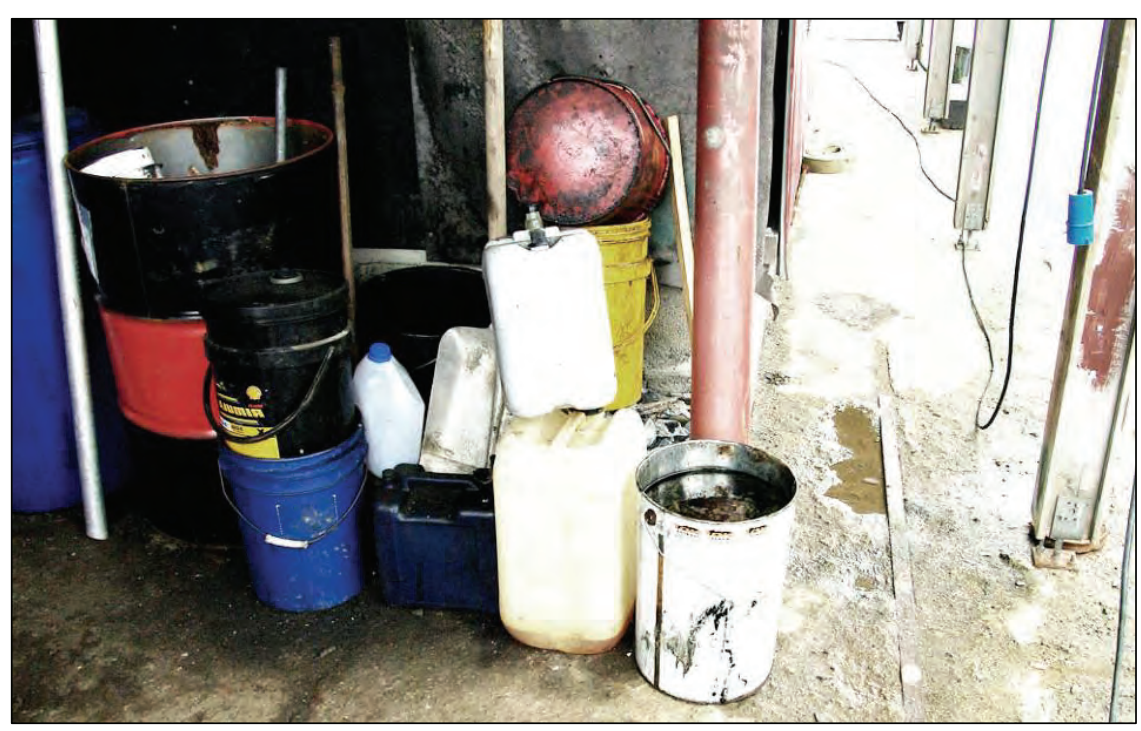

Figur 17. Uppsamling av oljeavfall i diverse öppna kärl på öppet område på varvet N4. 


\subsection{Småvarv på Åland}

Åland är ett självstyrt landskap i Finland, beläget i den södra delen av Bottniska viken (Figur 18). Landskapet med cirka 27000 invånare består av nästan 7000 öar, av vilka cirka 60 är bebodda. Östersjön är en av världens största brackvattenbassänger och området kännetecknas av en rad speciella hydrologiska och ekologiska förhållanden. På grund av stora skillnaderna i salthalten bildas det en haloklin på 60-80 meter i stora delar av Östersjön. Detta leder till en begränsad vattenomsättning i bottenlagren, vilket resulterar i syrebrist. Östersjön har varit och är starkt belastad av utsläpp av näringssalter och miljögifter från jordbruk, avlopp och industri (HELCOM, 2004). Under de senaste åren har miljöförhållandena förbättrats något (HELCOM 2008), men många arter påverkas fortfarande av miljögifter och systemet är således sårbart för ytterligare tillförsel av miljögifter.

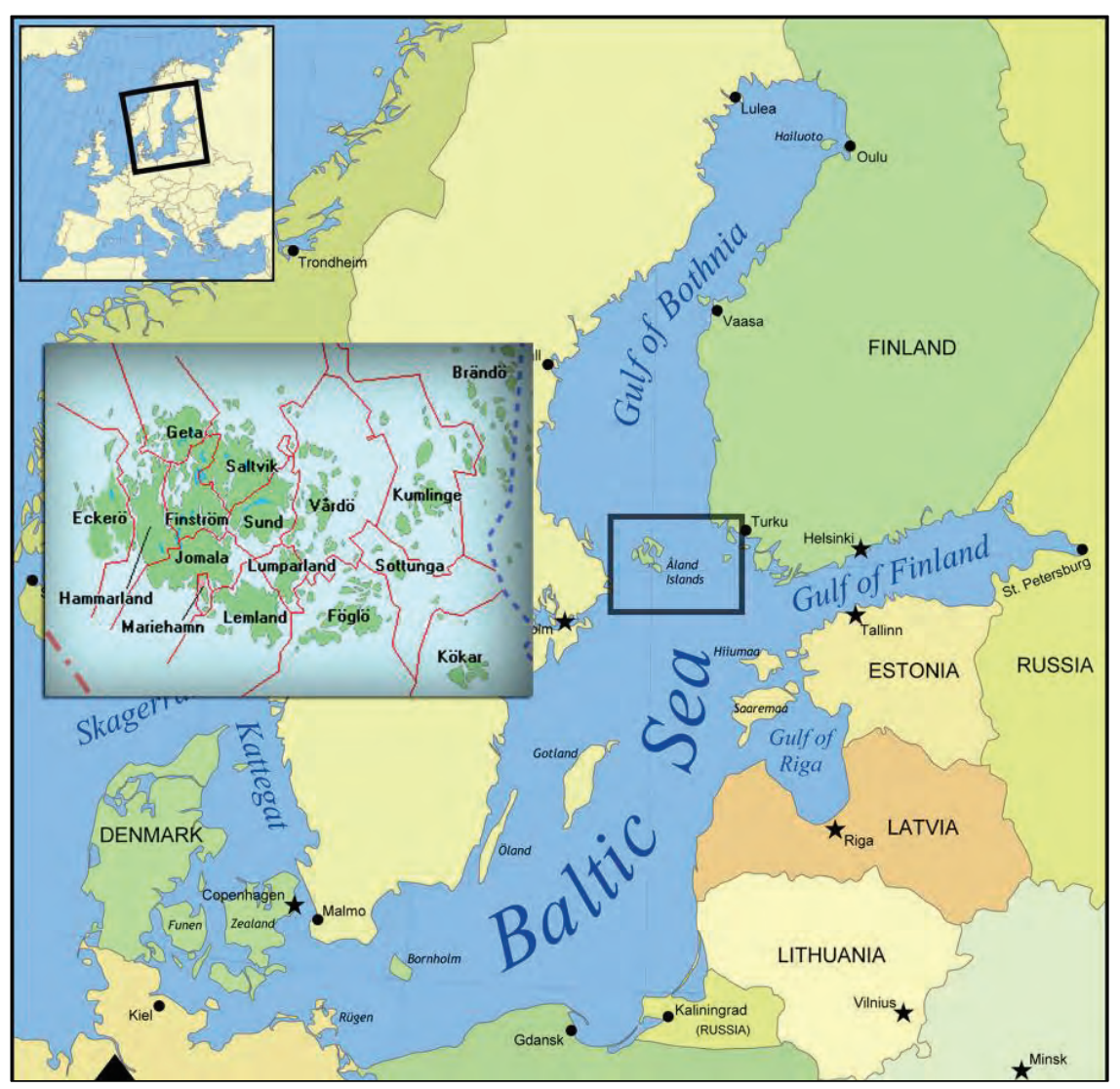

Figur 18. Åland ligger vid mynningen av Bottniska viken.

Det är mycket små skillnader mellan ebb och flod vid Åland och därmed få havsströmmar orsakade av tidvatten. Detta ger generellt en dålig omsättning av vattenmassorna runt varven. Det finns inte många fasta invånare här, men en mycket stor del av dem är båtägare, och det kom fram under intervjuerna att många svenska båtägare gärna kommer till Åland 
för att köpa bottenfärg med koppar (förbjuden i Sverige), eller för att få sina båtar bottenbehandlade här.

Förfrågan om besök gick till fem småvarv och vi genomförde besök på tre av dem. Ett varv i Mariehamn nekade oss tillträde och ville inte heller diskutera miljöfrågor i anslutning till varv och småbåtar med oss. Ett av de besökta varven ville inte låta oss ta bilder, trots att vi garanterade anonymitet i rapporten.

\subsection{1 Åländska företaget $\AA 1$}

Företaget ligger vid ett öppet sund i den södra delen av Åland, nära ett litet samhälle, med spridd bosättning runt själva varvet (Figur 19). Det har en lång historia som varv, men drivs nu som ett enmansföretag. All aktivitet sker under loppet av tre sommarmånader, och varvet betjänar huvudsakligen turisttrafiken i området. Största delen av kunderna är fritidsbåtar på genomresa.

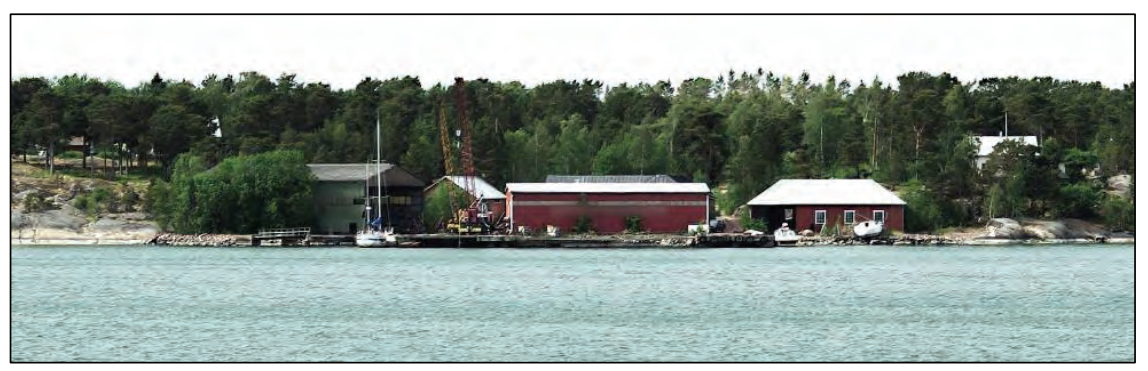

Figur 19. Varvet $\AA 1$ sett från sjösidan.

Varvet har tre rälsgående båtvaggor och en flyttbar kran avsedd för upptagning av segelbåtar. Företaget tar upp cirka 20 båtar per säsong och verksamheten består i väsentlig grad av reparationer av skrov och utrustning. Varvsägaren uppgav att det bara i liten grad utförs spolning/rengöring och bottenmålning. Han uppskattade en årsförbrukning på cirka 50 liter bottenfärg av typen "Norrøn” (norskt fabrikat).

Företaget har inte system för avhämtning av farligt avfall. Oljerester samlas i ett 200 liters fat, som inte har tömts på de senaste fem åren.

Området präglas av bristande underhåll och av skräp och skeppsvrak både på land och i havet utanför anläggningen (Figur 20). Vi kunde inte utföra en närmare inspektion av strandzonen eftersom vår närvaro uppenbarligen inte var önskad.

Företaget för ingen dialog med de lokala miljömyndigheterna. Företagsinnehavaren tycktes vara väl insatt i och kritisk till den lokala miljöpolitiken. Vi fick inte lov att ta bilder inne på varvsområdet under besöket. Fotografierna som presenteras här är således tagna från utsidan av varvsområdet. 


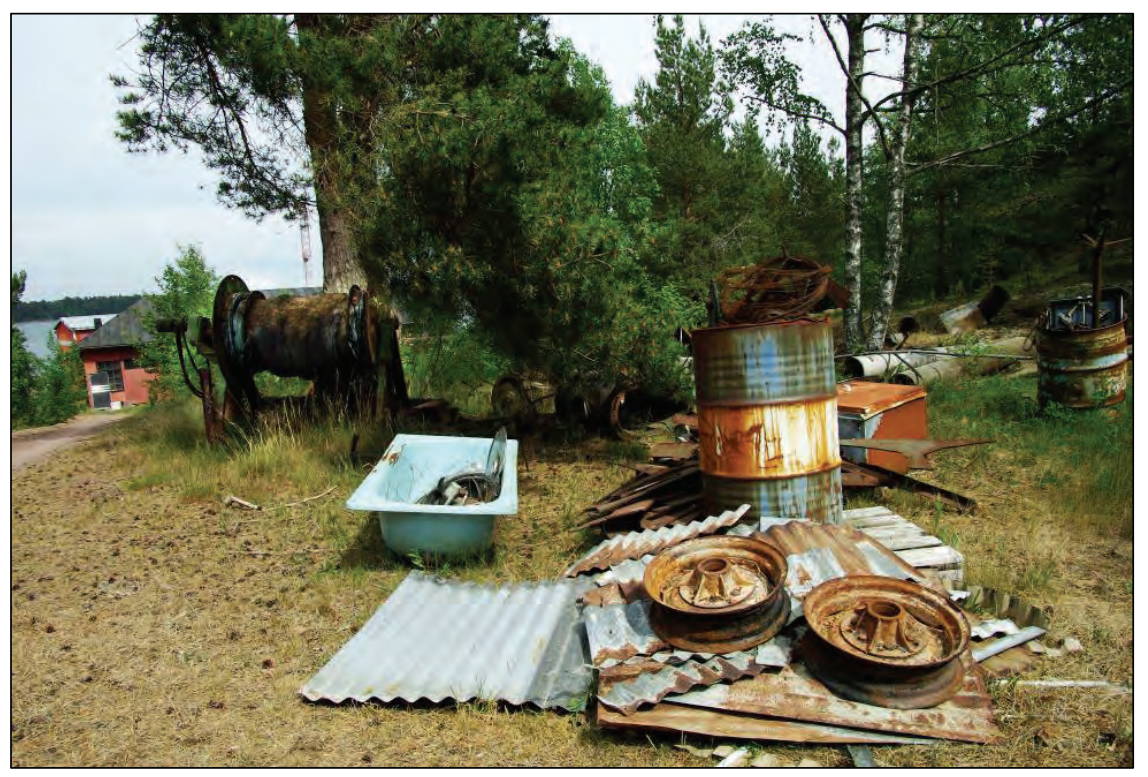

Figur 20. Samling av fast avfall vid infarten till varvet $\AA 1$.

\subsection{2. Åländska företaget $\AA 2$}

Detta företag ligger på den södra delen av Åland i ett glest befolkat område. Det är ett enmansföretag som i huvudsak utför reparationer och underhåll. Båtupptagningen sker med hjälp av en hjullastare som drar båtvaggor på hjul upp på en plattform av grus och betong (Figur 21).

Företaget tar upp cirka 30 båtar per säsong och en stor del av arbetet på båtarna utförs under vintersäsongen. Verksamheten är inriktad på den lokala flottan och båtstorleken är i huvudsak mellan 20 och 30 fot.

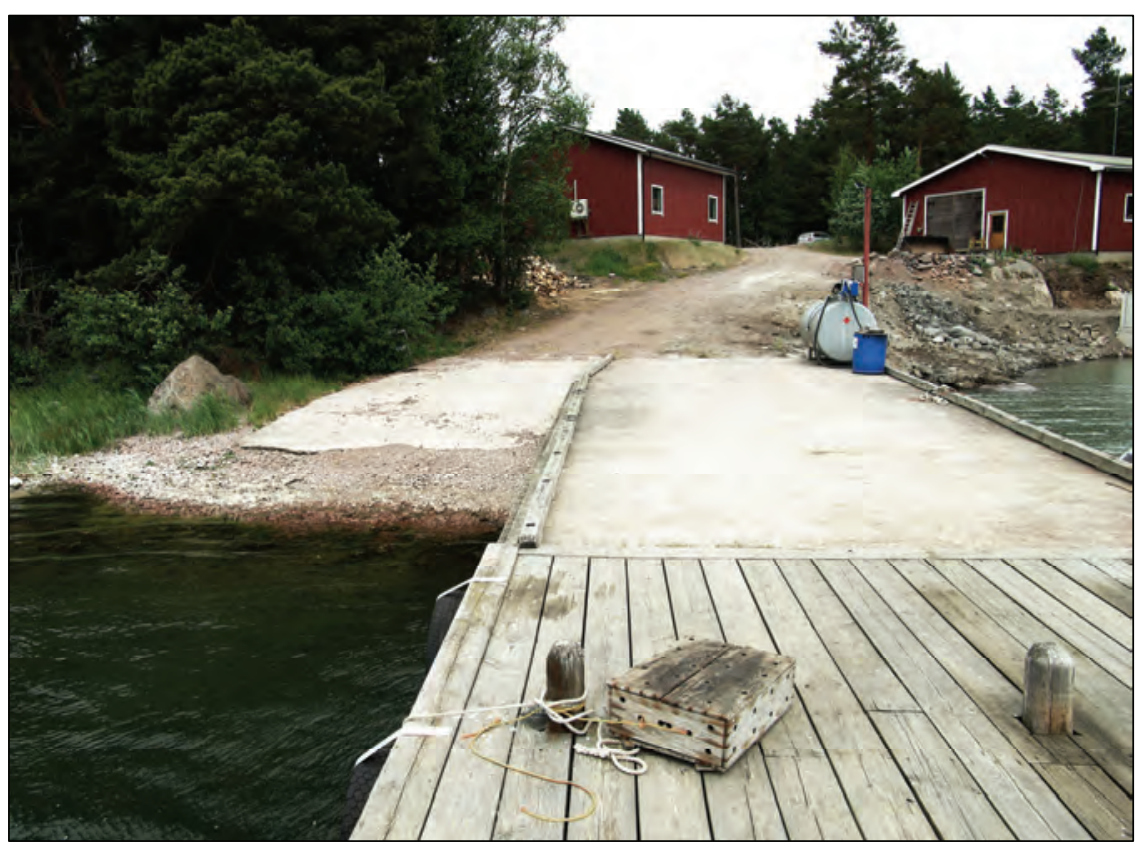

Figur 21. Brygga och plattform för upptagning av båtar på vagn med hjul på varvet $\AA 2$. 
Båtarna placeras ute (Figur 22) eller i en delvis öppen lagerhall, där förvaring och underhåll äger rum (Figur 23). Det fanns inga synliga anslag om eller containrar för farligt avfall på området.

Det var välstädat på hela området och det fanns inga synliga spår av avfall efter rengöring/bottenbehandling av båtar, även om spolvatten och färgrester spolas rakt ut i havet. Arbetet utförs i huvudsak av varvsägaren.

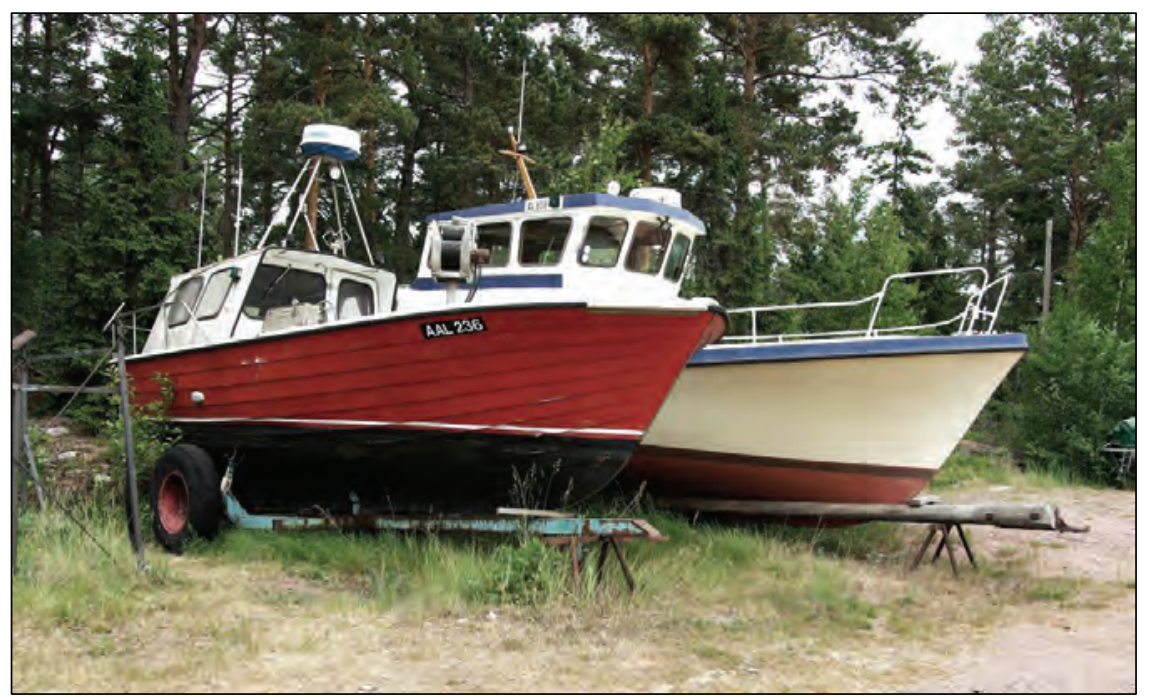

Figur 22. Båtförvaring utomhus vid varvet $\AA 2$.

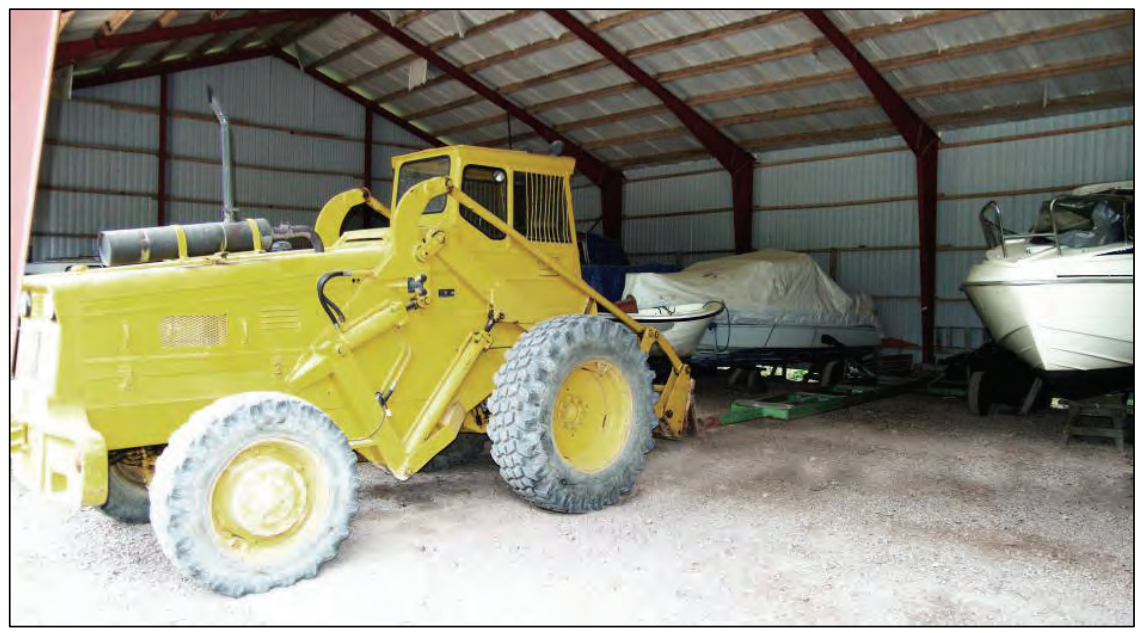

Figur 23. Hjullastare med båtvagga i lagerhallen för båtar på varvet $\AA 2$.

Vid en ytlig inspektion av strandzonen kunde man inte se spår efter verksamheten (Figur 24).

Varvets ägare hade en positiv inställning till miljövänlig drift, och viss, men begränsad, kunskap om regelverk, farliga ämnen och skadeverkningar. 


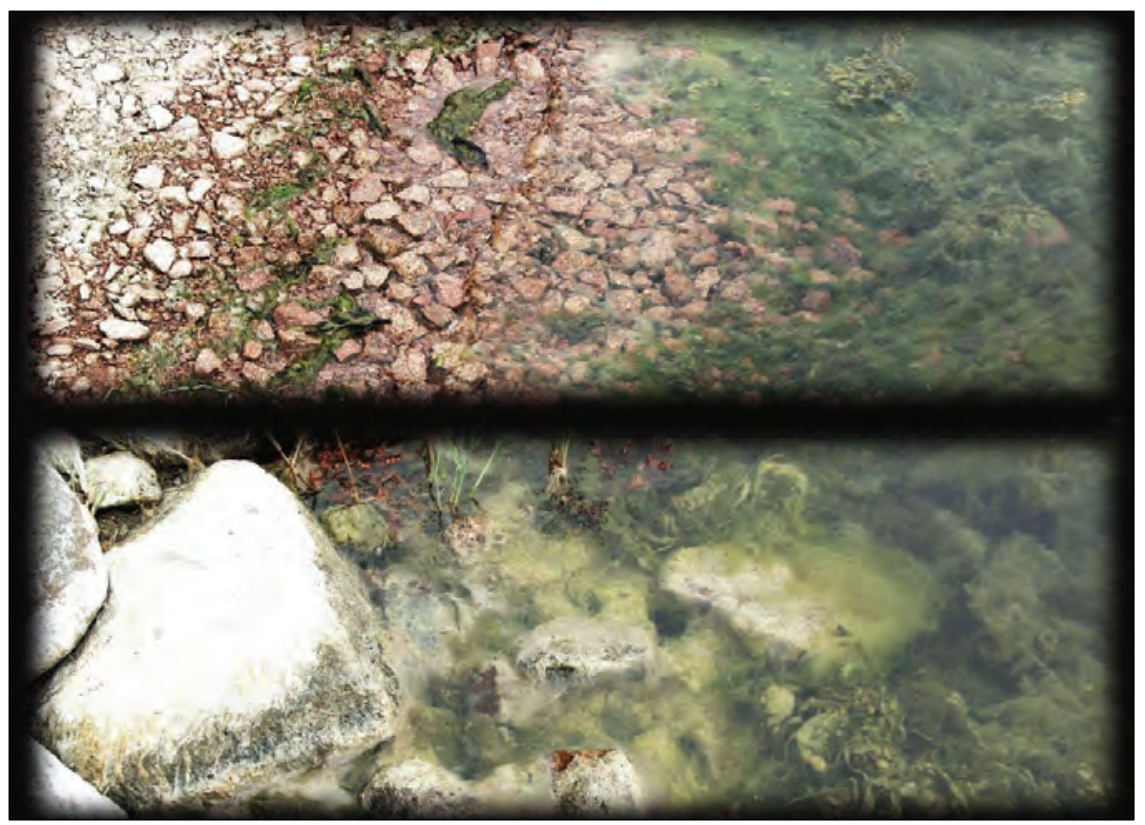

Figur 24. Detalj av strandzonen under uppsättningsplattformen (ovan), och av strandzonen som angränsar till plattformen (nedan) vid varvet $\AA 2$.

\subsection{3. Åländska företaget $\AA 3$}

Företaget ligger skyddat av två vågbrytare i ett samhälle på Åland, angränsande till ett öppet sund. Det är ett enmansföretag som omfattar en marina/båthamn med möjlighet till tömning av fast och flytande avfall, bunkring, uppläggning samt motor- och skrovservice. Verksamheten baserar sig på bred service, inklusive vinterförvaring för fritidsbåtar, många av dem lokala.

Upptagningen sker med hjälp av en specialanpassad truck via en ”slussanordning” med brygga på bägge sidor (Figur 25; Figur 26).

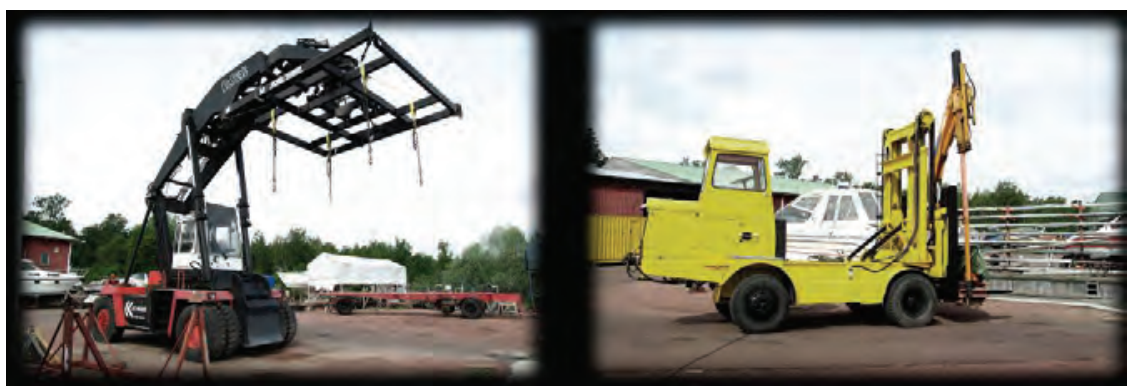

Figur 25. Truck för upptagning av båtar och truck för /mastservice på varvet $\AA 3$. 


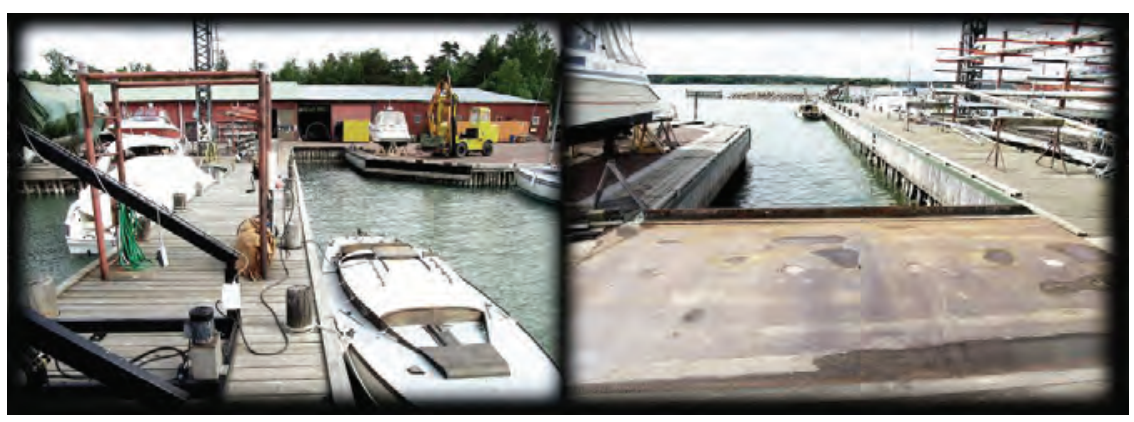

Figur 26. Brygga/sluss för upptagning av båtar med masttruck på varvet $\AA 3$.

Företaget tar upp, spolar och bottenbehandlar cirka 200 båtar per säsong; i huvudsak båtar mellan 20 och 33 fot. Ungefär 5 procent av dessa båtar skrapas/slipas, med eller utan dammsugning. Undantagsvis utförs rengöring med sandblästring (cirka 1 båt per säsong).

Spolvattnet med avfall rinner orenat ned i marken/havet. Allt annat avfall samlas på en välorganiserad miljöstation (Figur 27 - Figur 31).

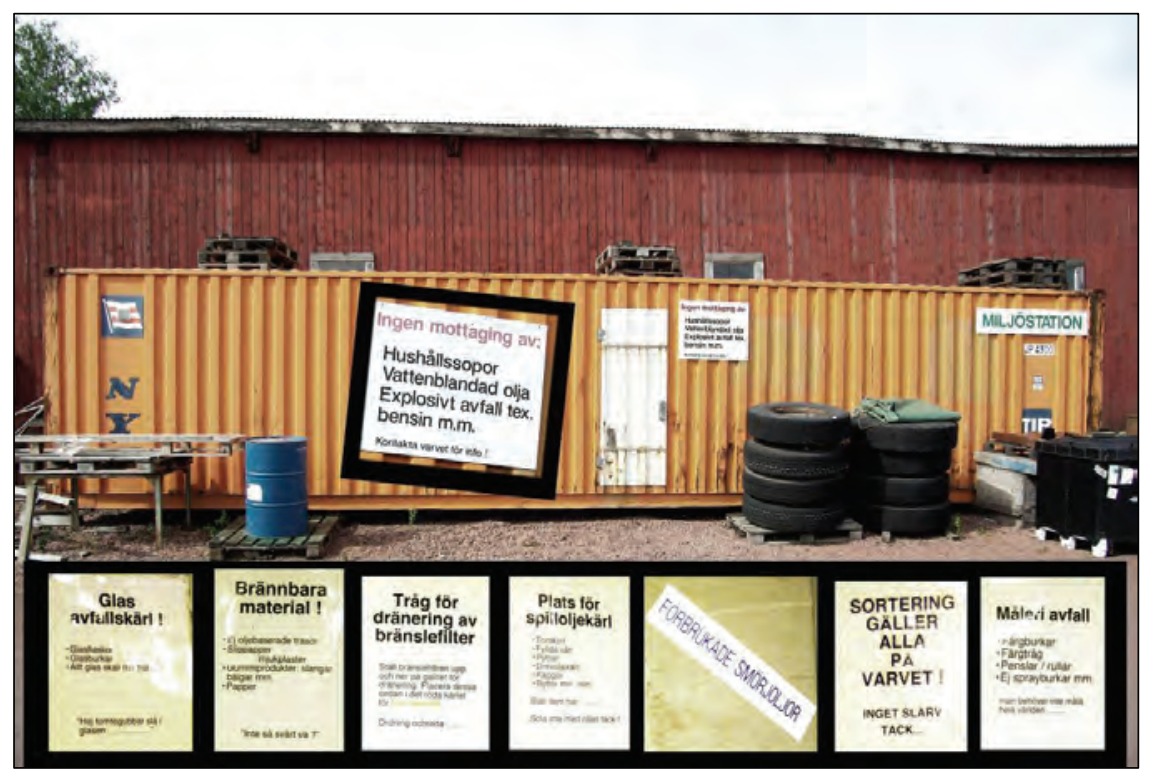

Figur 27. Låsbar miljöstation, och detaljer från anslag över olika uppsamlingsenheter (infällt och nedan). 


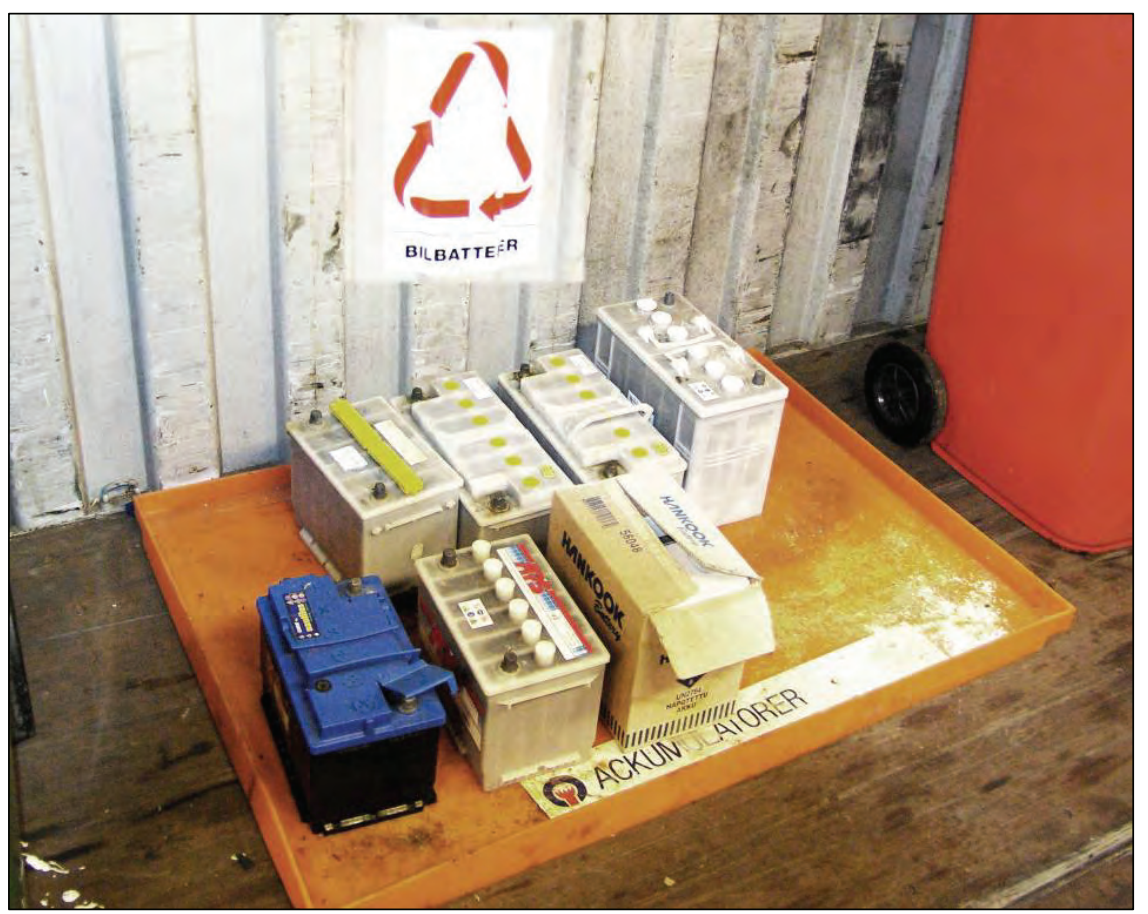

Figur 28. Uppsamlingskärl för använda batterier, varvet $\AA 3$.

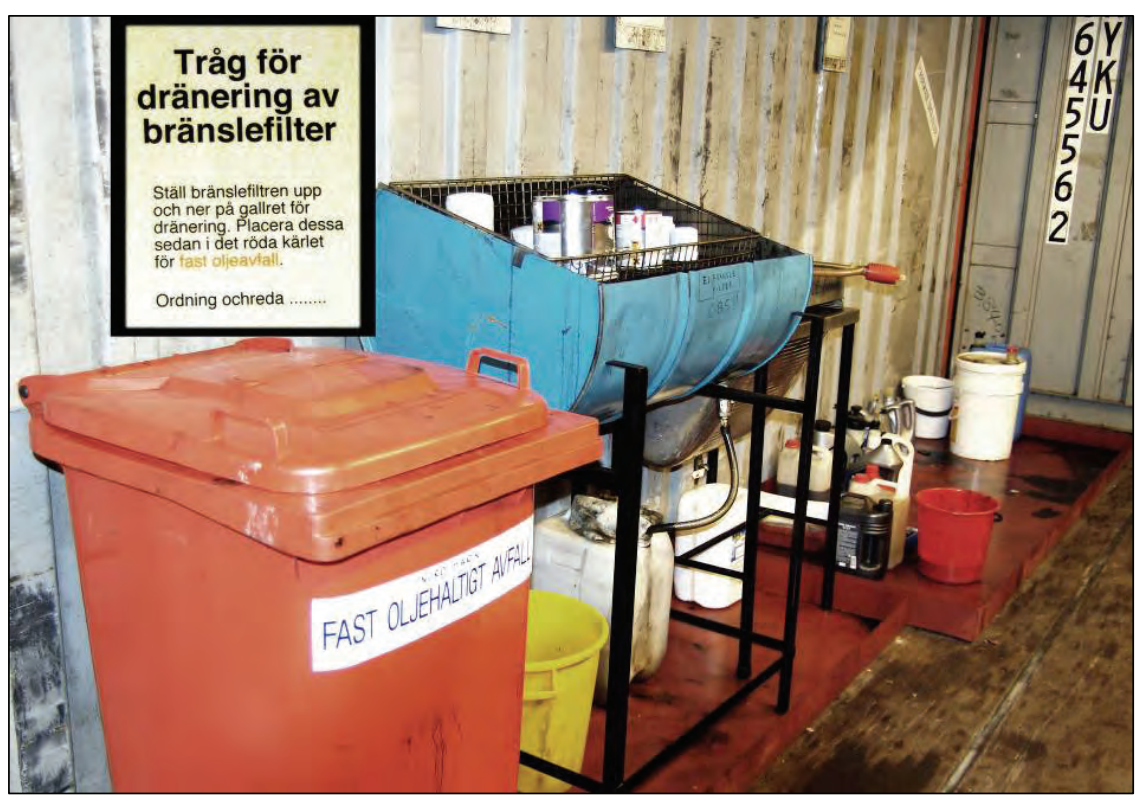

Figur 29. Dräneringskärl för olja på varvet $\AA 3$. 


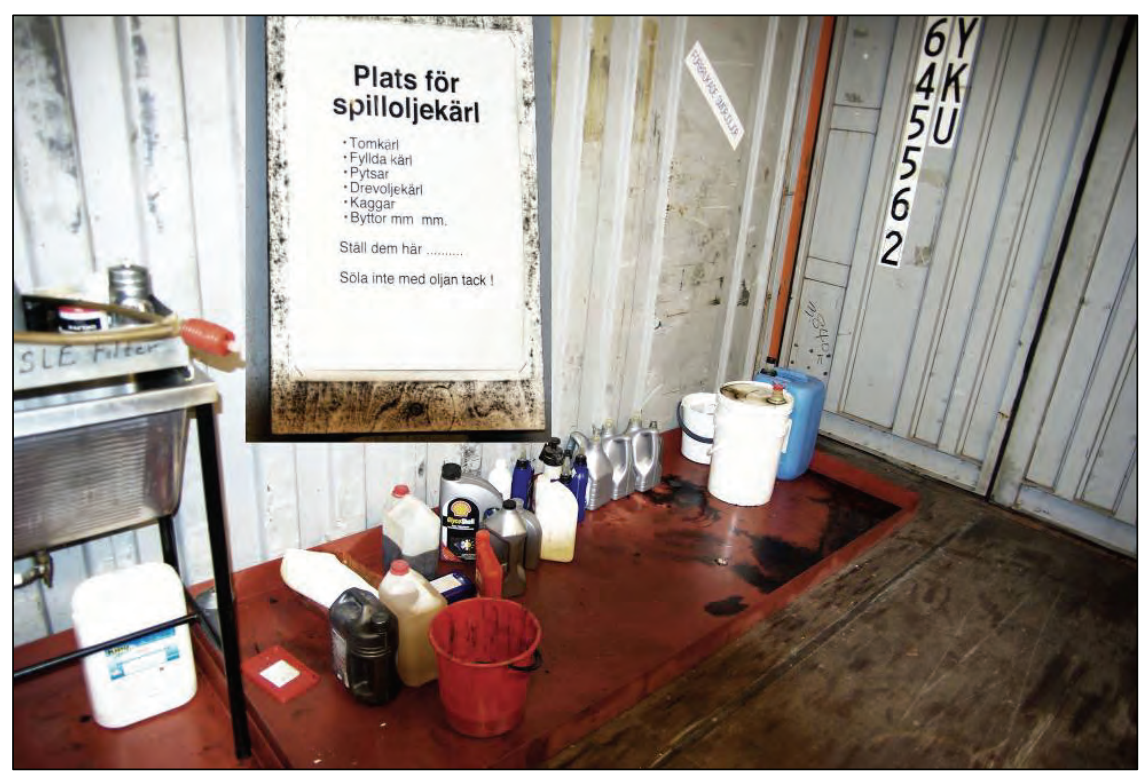

Figur 30. Uppsamlingskärl för tomma och fyllda kannor med oljeavfall på varvet $\AA 3$.

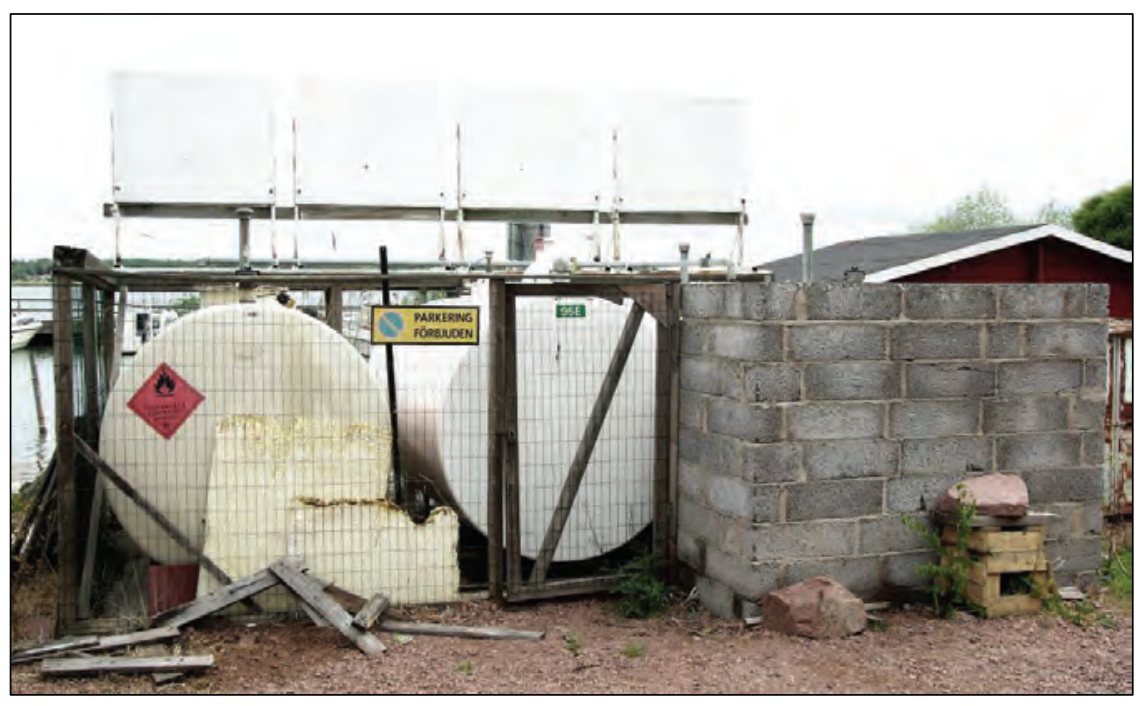

Figur 31. Uppsamlingstankar för olja och för annat flytande avfall på varvet $\AA 3$.

Företaget ansåg sig ha en god dialog med miljömyndigheterna och tycktes oavsett offentliga föreskrifter hålla en hög standard vad gäller miljövänlig drift av varvet. Man hade uppenbart goda kunskaper om miljöskadliga ämnen. Ägaren föreföll sätta en ära i att ha en verksamhet med välordnade förhållanden. Trots detta fanns inga planer på en uppsamlingsplattform för spolvatten/avfall (även om förhållandena är lämpliga för en sådan). Företaget överväger dock att skaffa en anläggning som kan användas till bottentvätt av båtar medan de ligger i havet (denna bottentvätt skulle då ersätta spolning och målning med antifouling). 
Jämfört med alla de övriga företagen som besöktes i samband med detta projekt måste detta varv räknas som ett mönsterföretag med hänsyn till sortering och lagring av farligt avfall. Men inte heller detta företag hade system för uppsamling och rening av spolvatten.

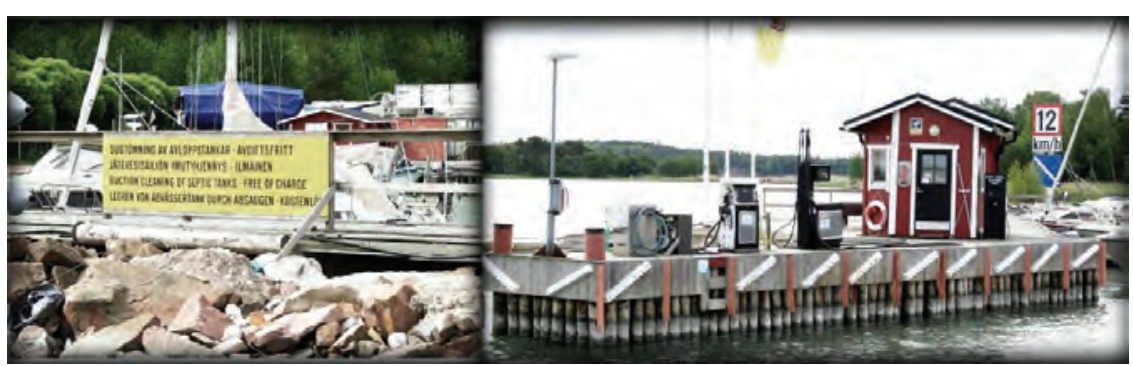

Figur 32. Information och bunkringsstation vid inloppet till marinan/varvet $\AA 3$.

\subsection{Småbåtsvarv på Färöarna}

Färöarna ligger i Nordatlanten och består av 18 öar omgivna av öppet hav på alla sidor (Figur 33). Ögruppen har knappt 50000 invånare, av vilka ungefär 17000 bor i och omkring huvudstaden Tórshavn.

Ögruppen ligger relativt samlat och de flesta öarna har långa smala fjordar med spridd bosättning och större och mindre samhällen. I de flesta fjordarna finns en eller flera stora laxodlingar. Miljöförhållandena i havsområdet runt Färöarna är generellt sett goda.

Via projektets kontaktperson vid miljöskyddsmyndigheten på Färöarna fick vi en förteckning över 11 stora och små varv. Vi valde ut ett litet (4-5 anställda) och två medelstora företag (15-20 anställda) från tre olika öar för vår undersökning. Orsaken till att de medelstora företagen togs med var att representanten för den lokala miljöskyddsmyndigheten önskade mer information om dessa, eftersom det finns väldigt lite uppgifter om skepps- och småvarv på Färöarna från tidigare studier. 


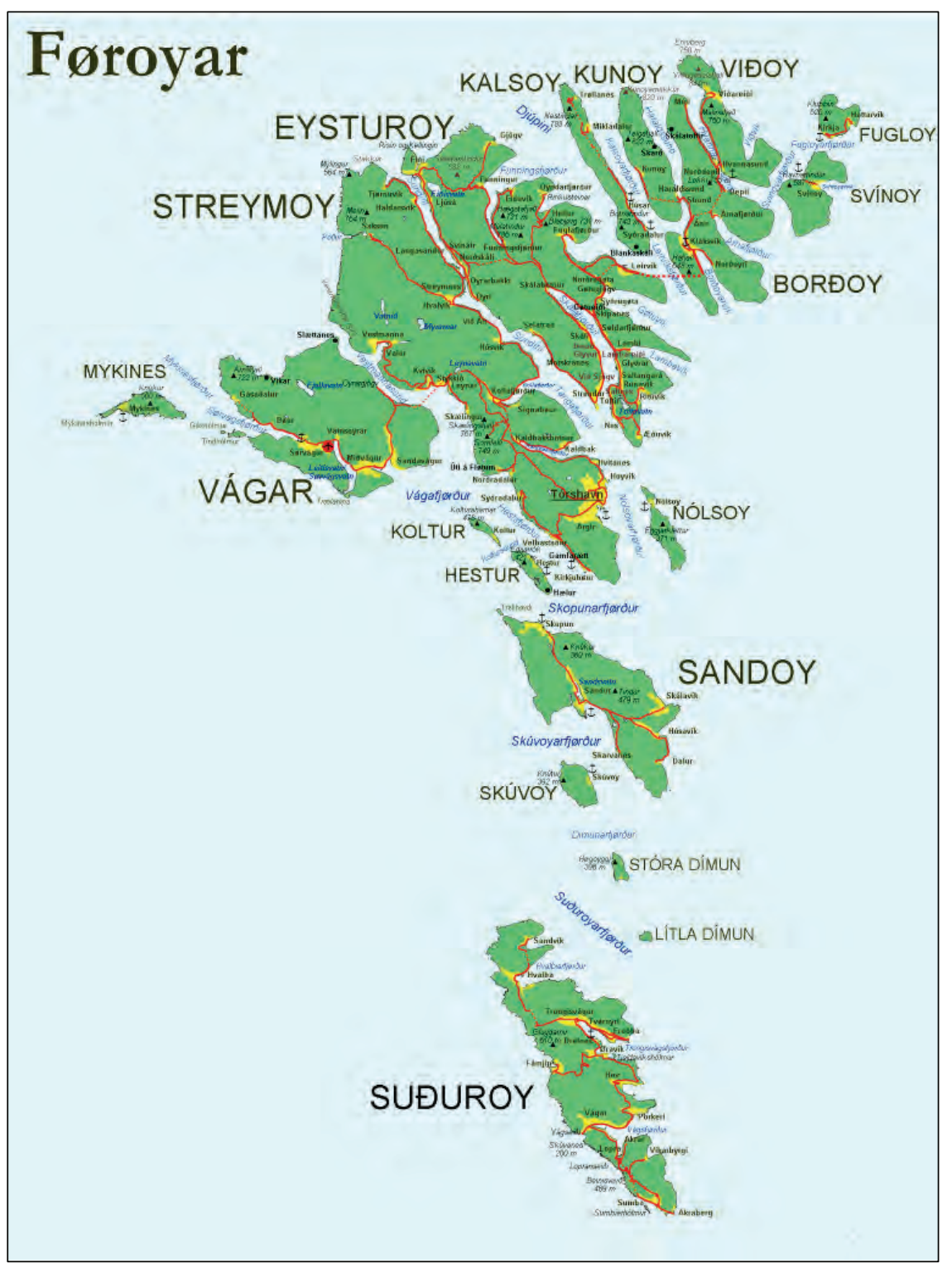

Figur 33. Översiktskarta över Färöarna.

\subsubsection{Färöiska företaget $F 1$}

Företaget har fem anställda och ligger i en liten by ytterst i en lång smal fjord. Det finns en fiskodling i fjorden.

Företaget sysslar i huvudsak med mekaniskt skeppsarbete och kombinerat med detta utför de också målning och bottenbehandling. De tar upp 50-60 båtar årligen, cirka fem i storleksklassen > 35 fot, resten är mellan 20 och 35 fot. Företaget erbjuder i huvudsak sina tjänster till fiskeflottan och fiskodlingsnäringen. 
Varvet har en rälsgående båtvagga placerad på en betongplattform som ligger i nivå med den naturliga strandbädden. Plattformen omges av tidvattenzonen med sand blandad med krossade musselskal (Figur 34). Det finns plats för två båtar på 30 fot samtidigt på varvet.

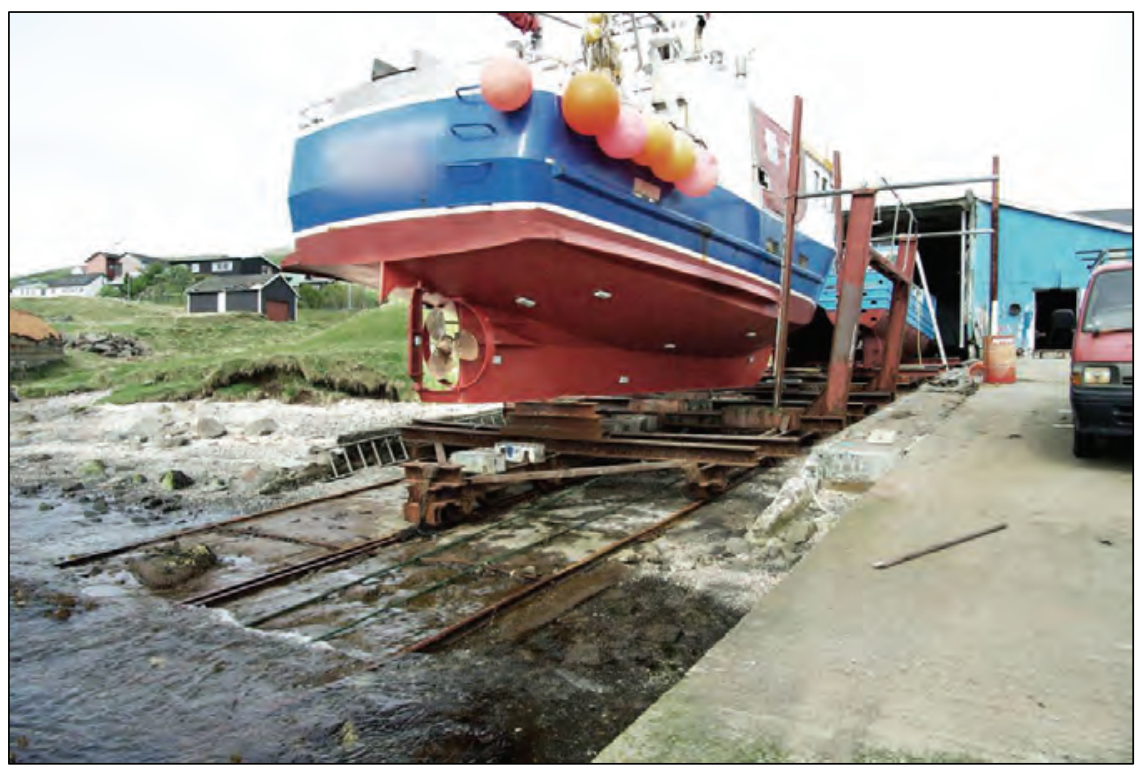

Figur 34. Varvet F 1: Rälsgående vagga på betongplattform.

Bottenbehandlingen består uteslutande av högtryckspolning och strykning med antifouling. Grundmålning med epoxibaserad tvåkomponentfärg förekommer, men oftast bara på slitna delar av skrovet. Varvet uppskattar att det går åt omkring 200 liter bottenfärg per år.

Det finns inget system för uppsamling av spolvatten eller avfall som uppstår i samband med rengöring/målning av båtar, eller vid olycksutsläpp av oljebaserat avfall. Företaget överväger alternativ för uppsamling från spolningen av båtar.

Varvets personal talade om att sanden blandad med musselskal som samlas vid slipens nedre del avlägsnas då och då. Sanden transporteras inte till någon avsedd deponi, utan lagras i närområdet. Sanden avlägsnas inte med tanke på miljögifter, utan snarare med tanke på vaggans driftssäkerhet.

Oljehaltigt avfall samlas i omärkta tunnor (Figur 35), och levereras till/avhämtas av det kommunala avfallsverket (IRF). Metaller, speciellt använda zinkanoder, samlas och säljs för omsmältning. Annat metallavfall sorteras och avhämtas inte systematiskt. 


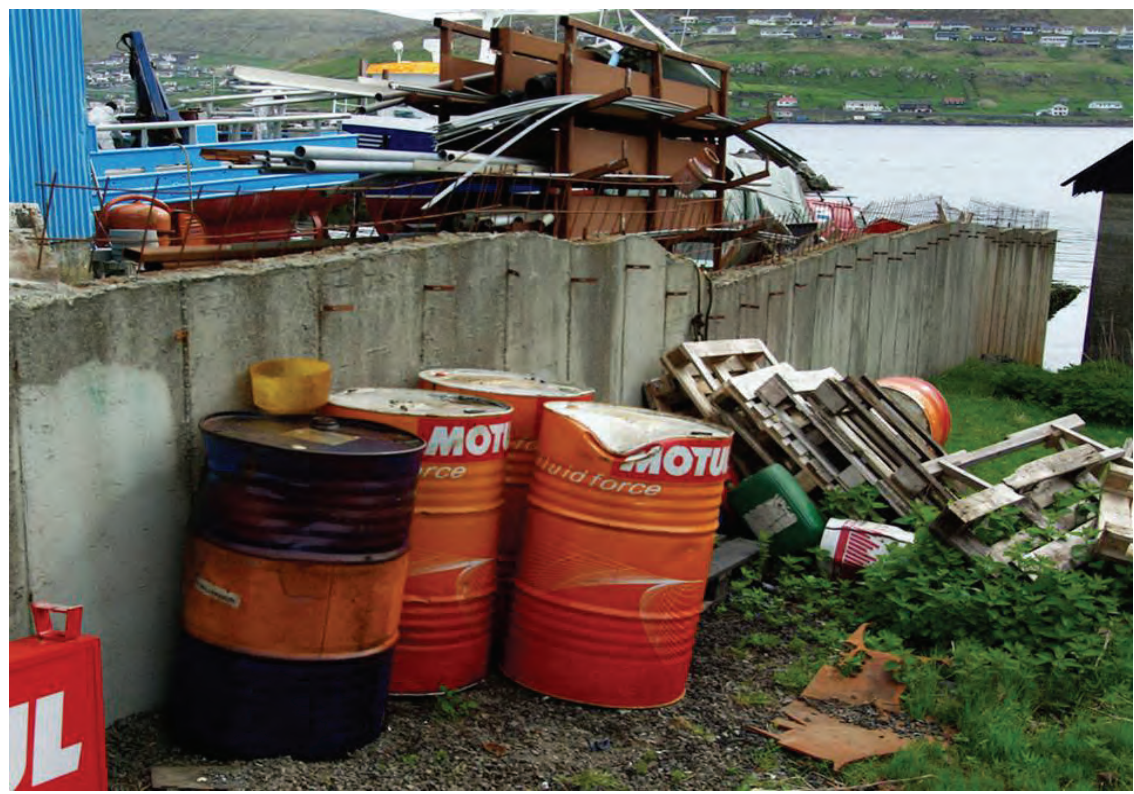

Figur 35. Tunnor för uppsamling av spillolja.

Bottenfärgen som används är i huvudsak hård bottenfärg av märket Hempel (Figur 36). Företagsinnehavaren är medveten om att det används miljöfarliga ämnen i verksamheten och vet också var produktdatablad är tillgängliga (på internet). Kunskapen om regelverk, vilka ämnen som är giftiga och hur sådan giftverkan tar sig uttryck var mycket begränsad. Vad gäller lagligheten hos de bottenfärger som används, litar han på att leverantören (importören av Hempelfärger vid Tórshavn skeppsvarv), bara säljer tillåtna ämnen.

Företaget vill inte att verksamheten ska orsaka miljöskador och saknar en dialog med specialister och med den offentliga miljöförvaltningen. De upplever att det finns lite information och få riktlinjer att stödja sig på.

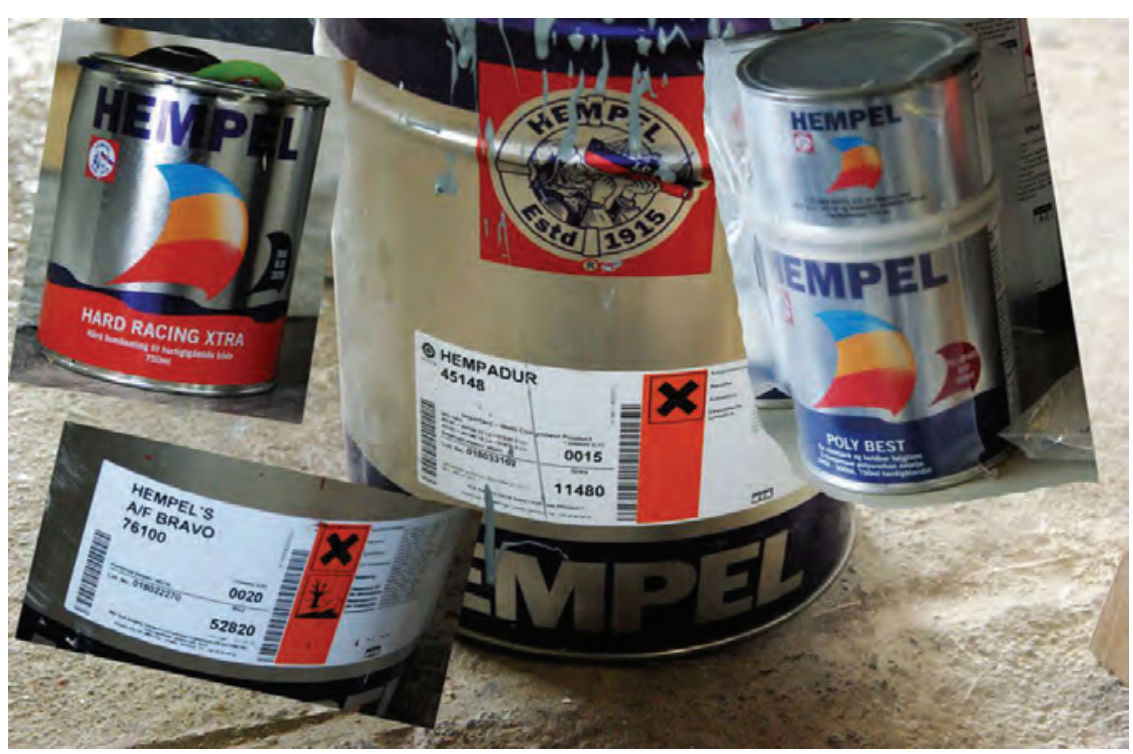

Figur 36. Exempel på ämnen som används på företaget F1. 
Det finns inga synliga spår av avfall från varvet i strandzonen, och växtoch djurlivet var av allt att döma jämförbart med motsvarande opåverkade områden (Figur 37).

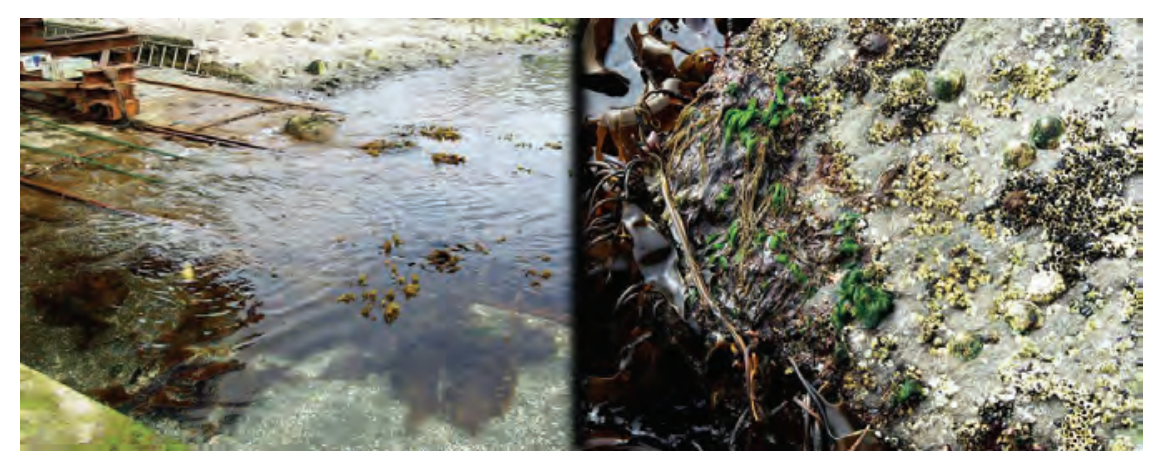

Figur 37. Sockertång (Saccharina sp.) växer rakt under slipen, och i strandzonen alldeles intill trivs stortare (Laminaria sp.), fleråriga kolonier av havstulpan (Balanus sp.) och skålsnäckor (Patella sp.).

Om det utifrån miljöhänsyn kommer krav om kostsamma ändringar av rutiner, förväntar man sig att samma regler ska gälla för alla som är verksamma inom branschen och angränsande branscher. Man fäste särskild uppmärksamhet vid den oorganiserade formen för underhåll av båtar som försiggår på stora kajer/uppläggningsplatser, där verksamheten baserar sig på att båtarna lyfts upp av mobila kranar (Figur 38 - Figur 40). Verksamhetsägaren kunde gärna tänka sig en form för certifiering av all sådan verksamhet.

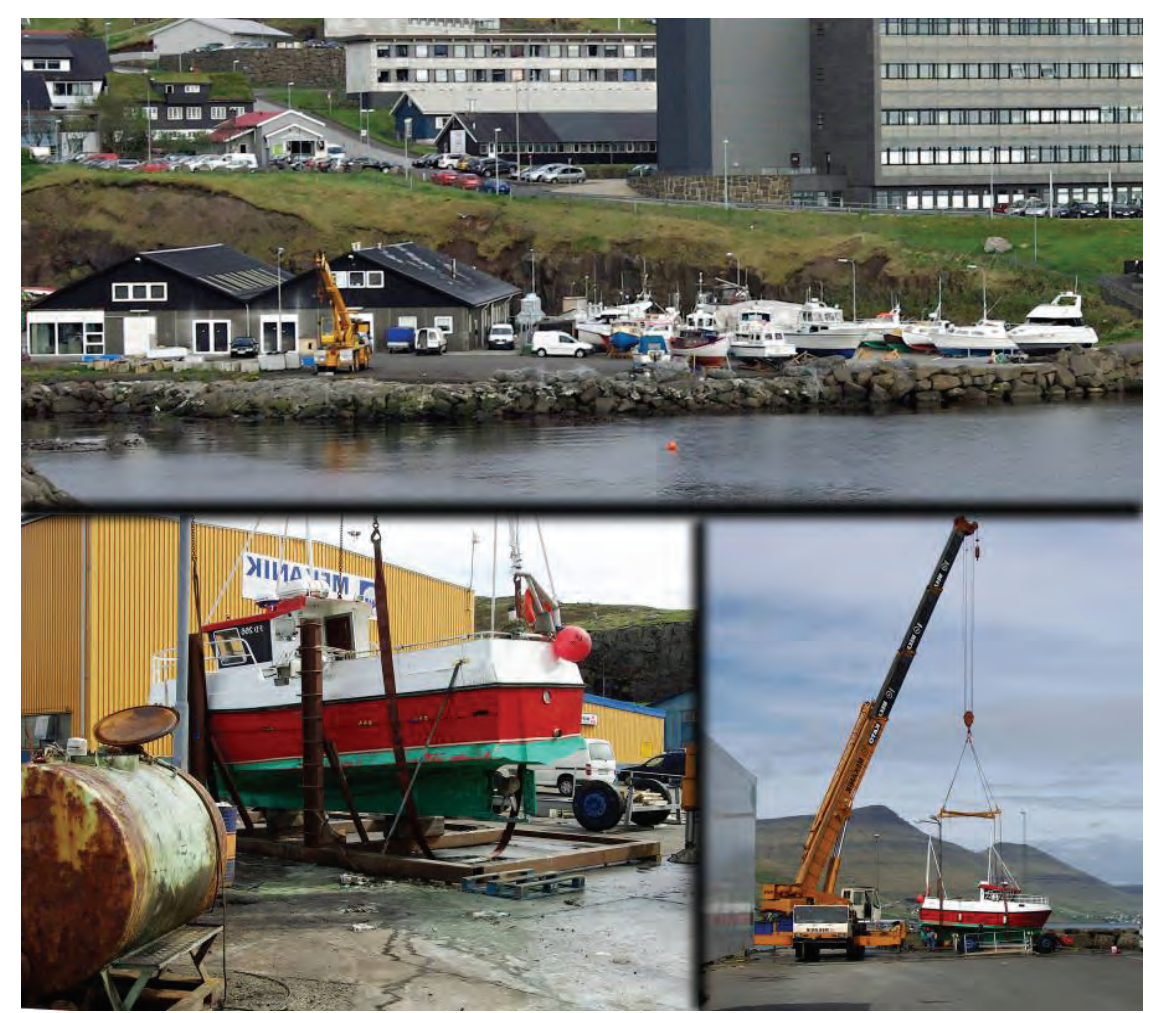

Figur 38. Exempel på uppläggning på kaj med mobil kran. 


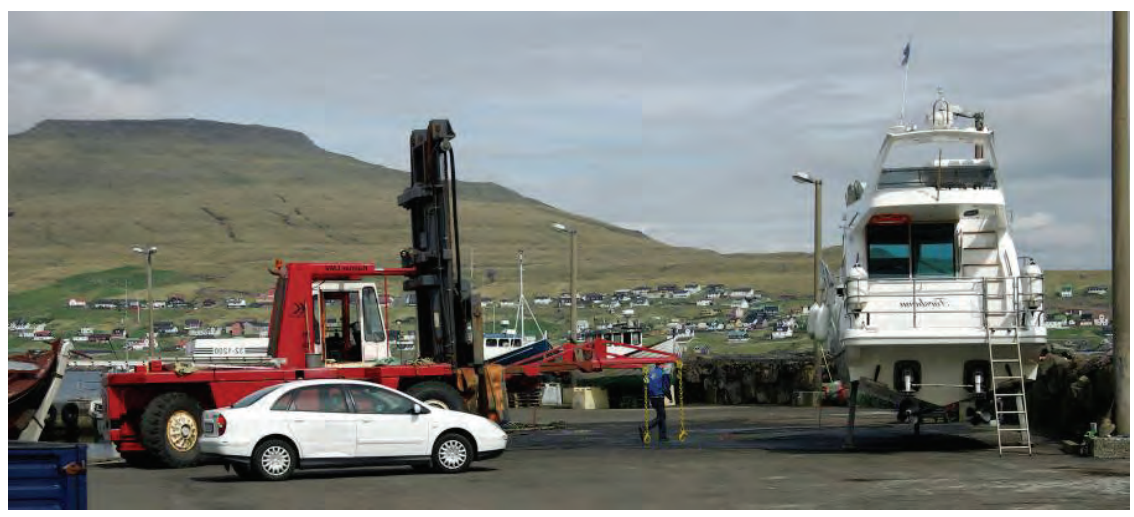

Figur 39. Exempel på uppläggning med gaffeltruck (Färöarna)

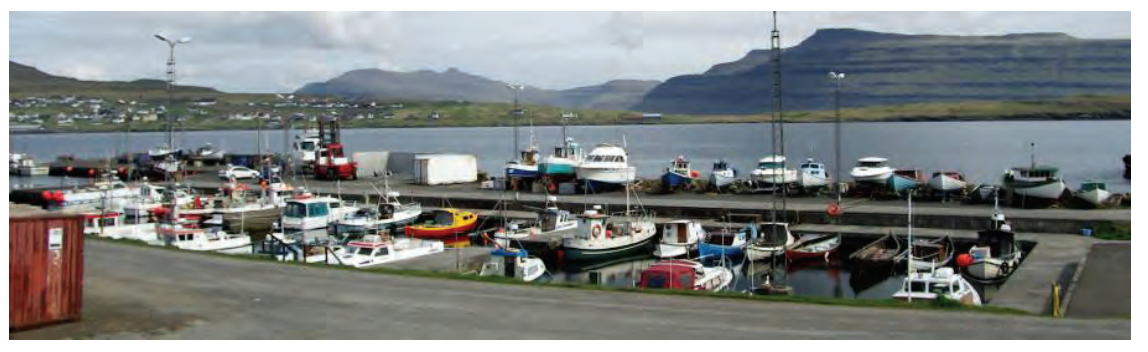

Figur 40. Exempel på uppläggningsplats för båtar på kaj (Färöarna)

\subsubsection{Färöiska företaget $F 2$}

Företaget ligger innerst i en fjord $\mathrm{i}$ en tätort med mycket annan industri $\mathrm{i}$ närheten (Figur 41; Figur 42). Det ligger fiskodlingar längre ut i samma fjord.

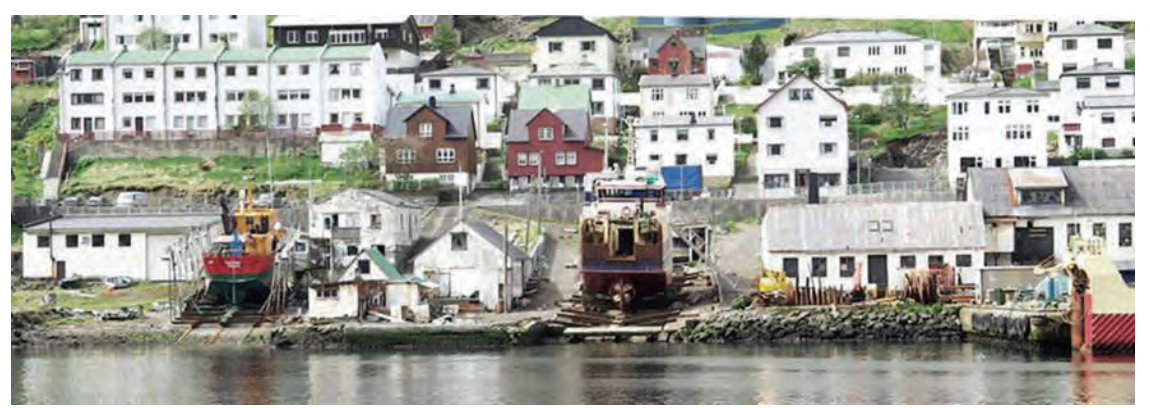

Figur 41. Företaget $F 2$ har ett mindre varv som närmaste granne (till vänster). 


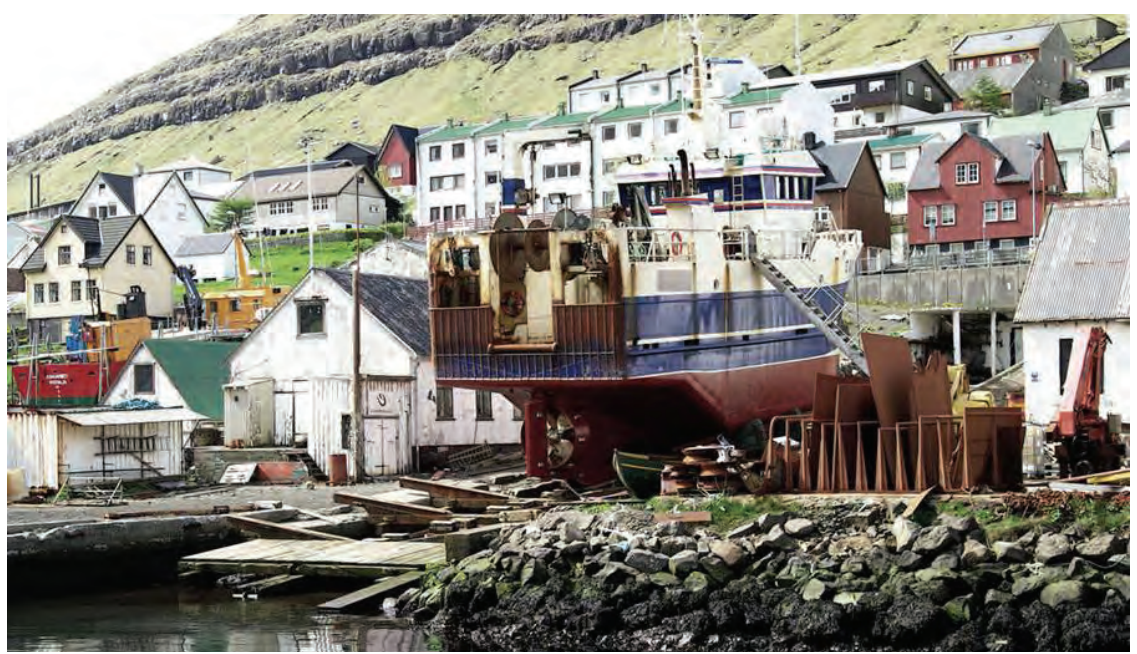

Figur 42. Företaget ligger, liksom de övriga besökta varven, mycket nära bebyggelsen.

Varvet har cirka 20 anställda och det tar årligen upp ungefär 15 plastbåtar i storleksklassen 20-35 fot och cirka 15-20 större stålfartyg (35-80 fot).

Företaget sysslar i huvudsak med mekaniskt skeppsarbete och kombinerat med detta utför de ofta också målnings- och bottenbehandlingsuppdrag. Varvet har en stor rälsgående vagga i en helgjuten betongränna (Figur 43).

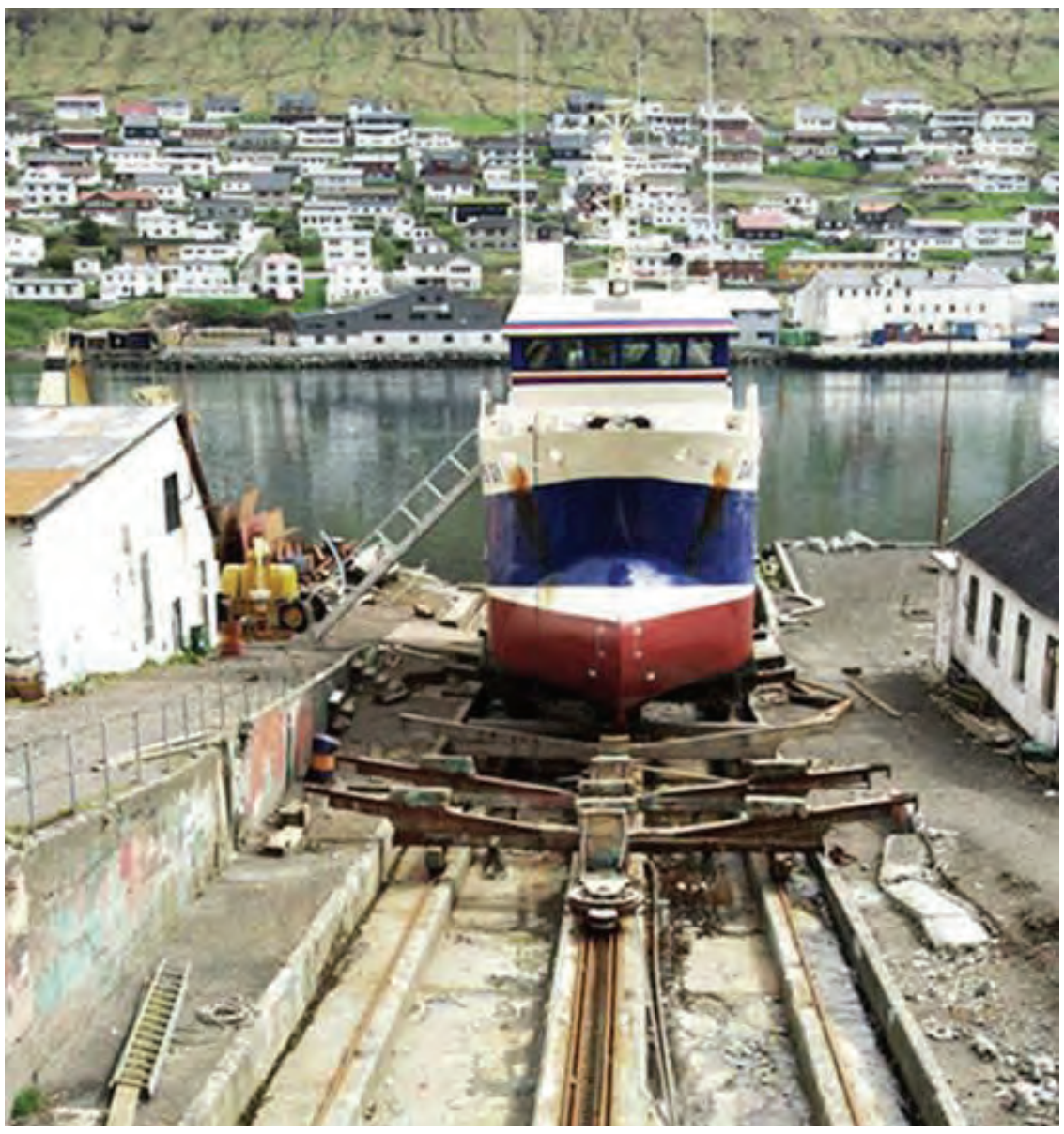

Figur 43. Rälsgående vagga placerad i en helgjuten ränna (betong). 
Bottenbehandlingen består uteslutande av högtryckspolning (vatten), tvätt och användning av rostlösande medel, samt strykning med antifouling. Bottenfärgen är av märket Hempel, köpt av en importör i Tórshavn. Varvet räknade med en genomsnittlig förbrukning på cirka 50 liter bottenfärg per båt, och en årsförbrukning på ungefär 1400 liter. Det fanns ingen uppsamling av spolvatten, färgrester och liknande. Företaget hade system för källsortering av eget avfall, men mycket avfall (plast, trä och metall) låg utspritt på företagets område. Oljerester uppsamlas och avhämtas av ett lokalt bolag. Ägaren visste inte hur detta avfall hanteras vidare.

Företagets representant var väl insatt i reglerna för utsläpp och hantering av farliga ämnen och hade goda kunskaper om andra länders restriktiva krav på rutiner. Han hade begränsad kännedom om vilka ämnen som var förbjudna att använda och trodde att vissa giftiga ämnen släpps ut som ett resultat av verksamheten. Han efterlyste en bättre uppföljning/satsning från de lokala offentliga myndigheterna för att få bättre ordning på alla företag. Utan en sådan uppföljning, med information, rådgivning och regler, ansåg han det föga troligt att företagen ska införa miljövänligare lösningar. Han hänvisade till att utländska fartyg är ålagda att leverera sorterat avfall (mot kvittering) när de kommer till varvet, men den vidare hanteringen av avfallet är det ingen uppföljning på.

Företaget hade inte ålagts att ändra sina driftsrutiner; de hade inte genomfört eller planerat åtgärder för att begränsa utsläpp av farliga eller okända ämnen.

Representanten ansåg personligen att ordning och reda på arbetsplatsen var mycket önskvärt, utan att idén tycktes ha genomförts på varvet.

Strandzonen nedanför slipen var i någon mån präglad av industriverksamheten i området (Figur 44).

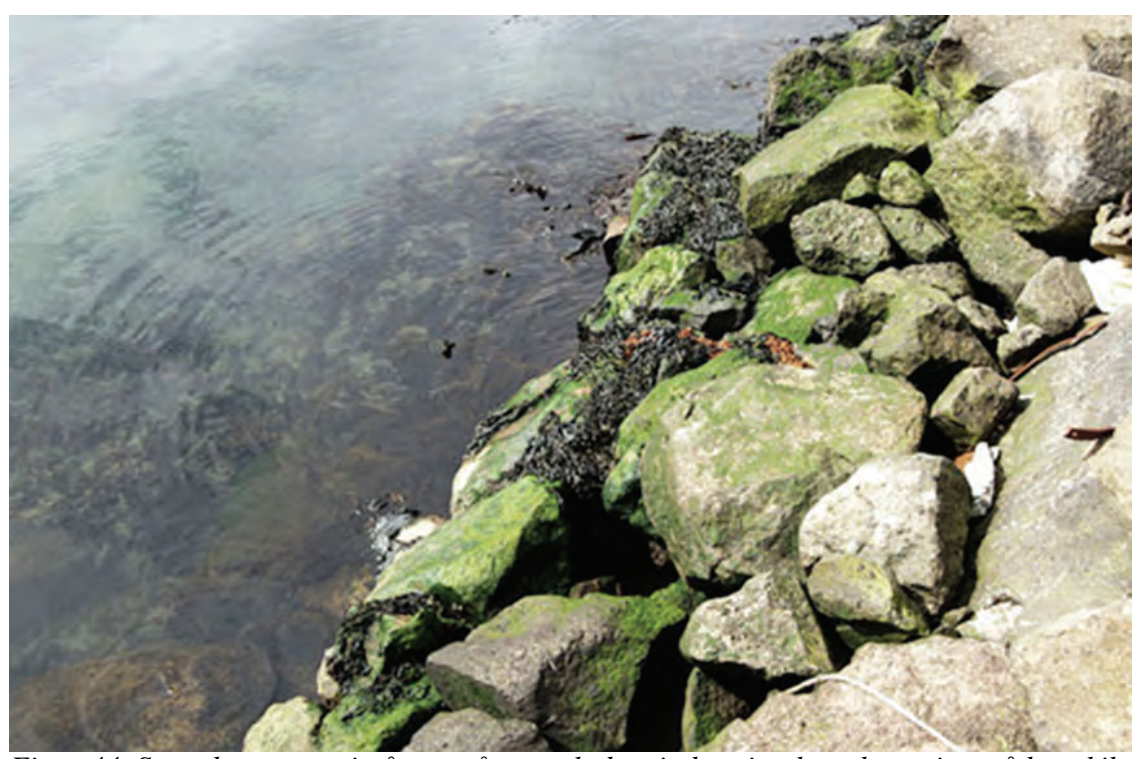

Figur 44. Strandzonen var i någon mån präglad av industriverksamheten i området: skikt av grönalger, oklart vatten och avfall. 


\subsubsection{Färöiska företaget $F 3$}

Företaget ligger längst inne vid en fjord $\mathrm{i}$ en tätort med annan industri i närheten. Det finns fiskodlingar längre ut i samma fjord, som i den innersta delen (cirka $1 \mathrm{~km}$ ) är ungefär 9 meter djup.

Varvet har cirka 15 anställda och betjänar nästan uteslutande stålbåtar, cirka 25-30 större än 50 fot och cirka 5 mindre än 50 fot per år. Företaget sysslar i huvudsak med mekaniskt skeppsarbete och kombinerat med detta tar de ofta målnings- och bottenbehandlingsuppdrag.

Varvet har en stor rälsgående vagga på en helgjuten betongplattform (Figur 45), och en rälsgående vagga utan gjuten plattform (Figur 46).

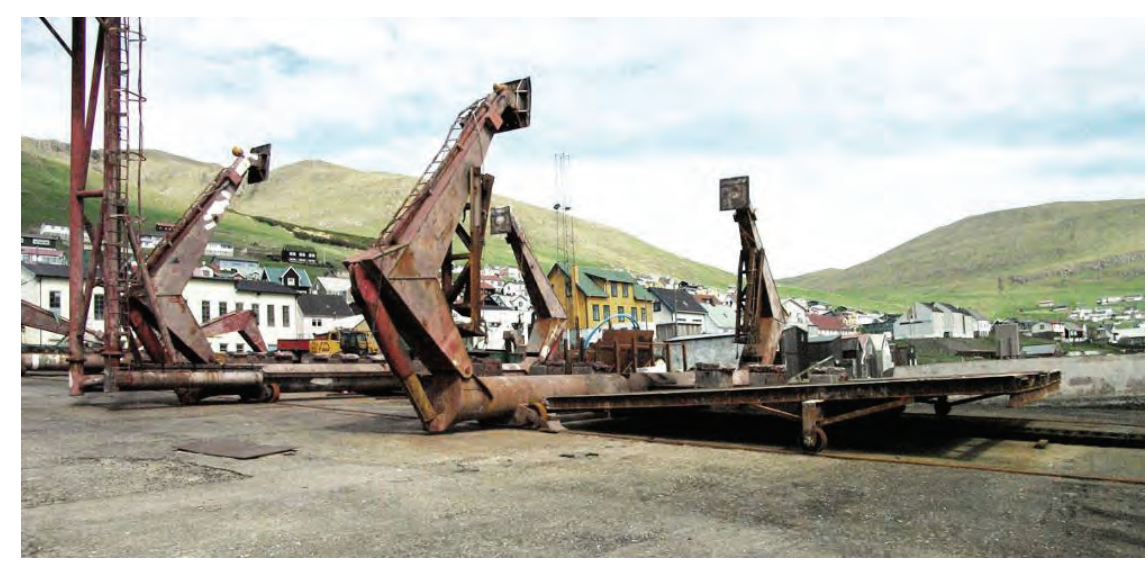

Figur 45. Rälsgående båtvagga på helgjuten plattform vid varvet F3.

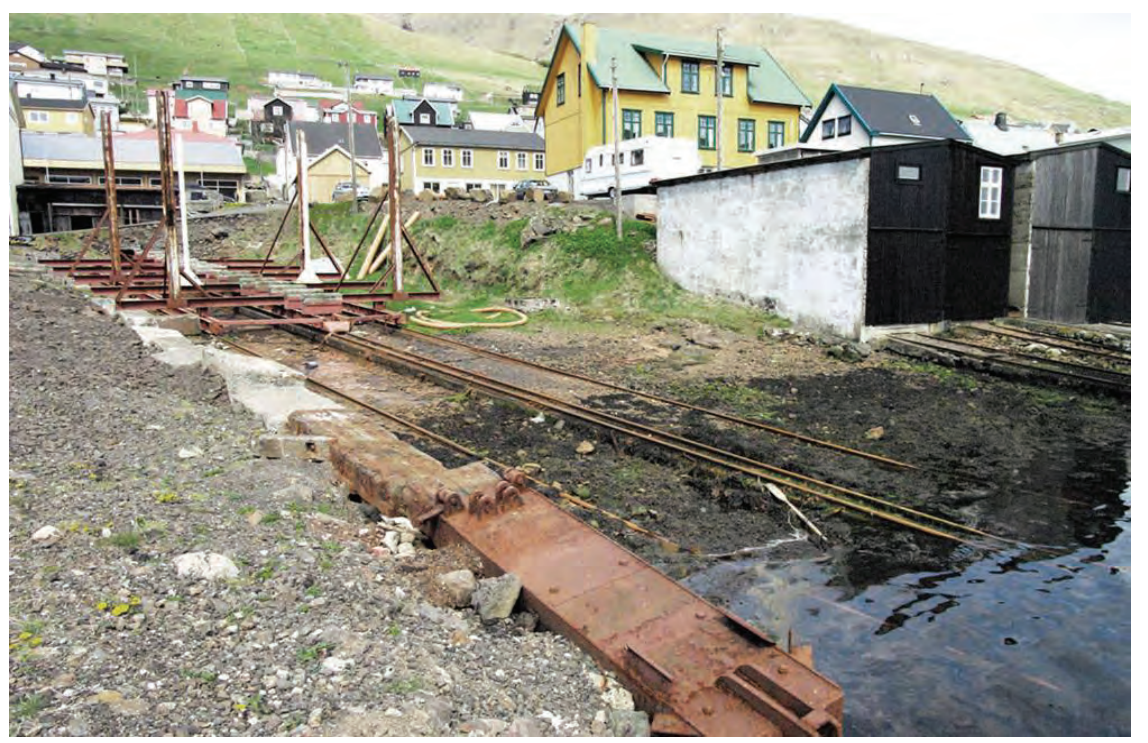

Figur 46. Rälsgående vagga på naturligt underlag vid varvet F3. 
Bottenbehandlingen består uteslutande av högtryckspolning (vatten), tvätt och användning av rostlösande medel (Kemilux), samt strykning med antifouling. Typen av bottenfärg bestäms av kunden, vanligtvis används märkena Hempel, Sigma eller International (Figur 47). I genomsnitt används cirka 40 liter bottenfärg per båt, totalt cirka 1400 liter per år.

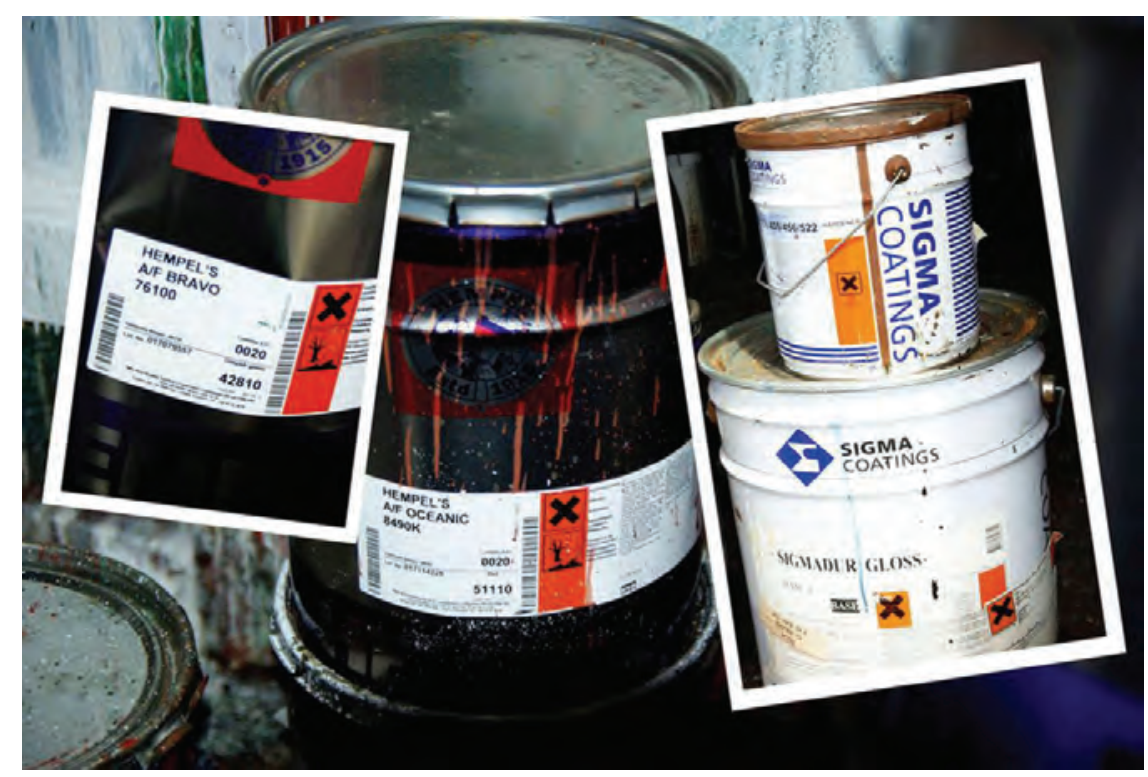

Figur 47. Exempel på kemikalier som används vid varvet F3.

Företagsledningens representant kände inte till vilka regler som gäller för utsläpp av kemikalier eller avfall från båtbehandling i miljön, och hade begränsade kunskaper om vilka ämnen det är förbjudet att använda. Han ansåg att det egna företaget släpper en del miljöskadliga föreningar ut $\mathrm{i}$ naturen, men visste inte vilka och inte heller vilken typ av skadeverkningar de har. Företaget har inte fått några villkor från miljömyndigheterna och de saknade en dialog med dem.

Företaget hade projekt på gång för att skapa system för uppsamling av fasta ämnen från slipen. En planerad åtgärd var en flyttbar fysisk avstängning vid slipens nedre del (Figur 48), där avfall kan samlas upp och fraktas till avfallsdeponi. Vidare har man planerat att gjuta en plattform under den mindre slipen. 


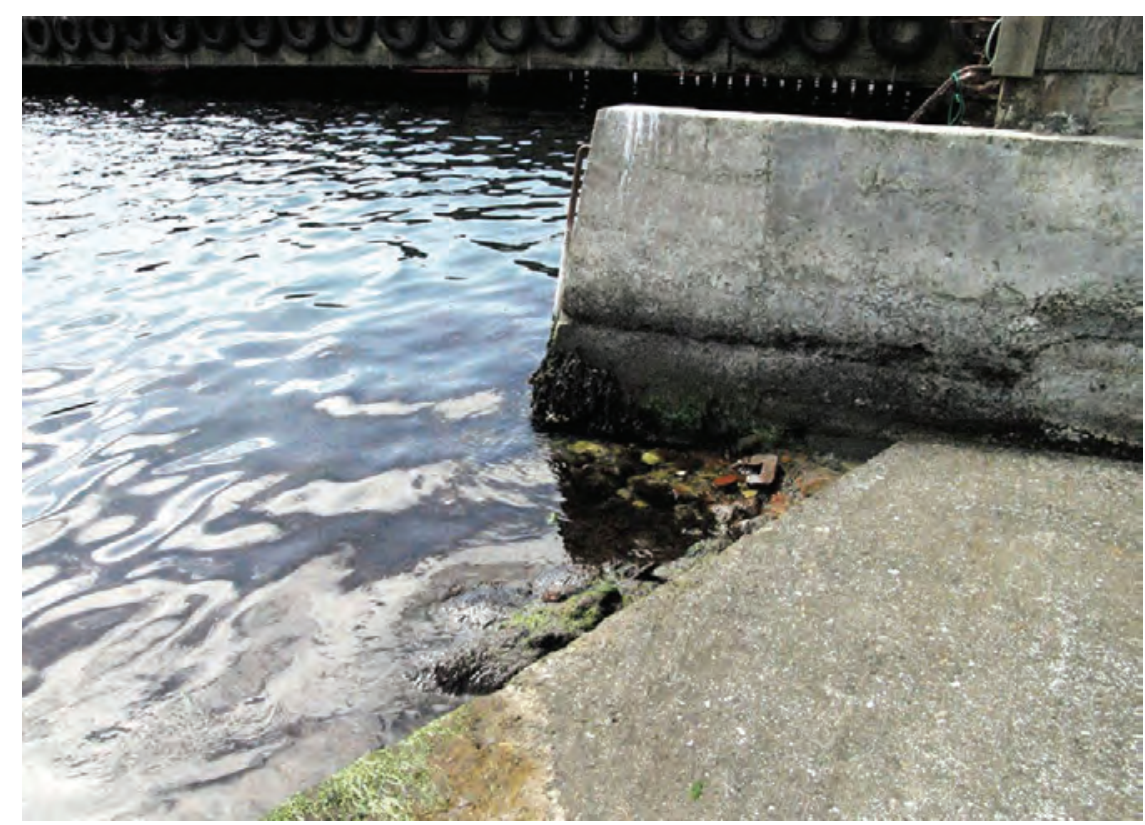

Figur 48. Nedre kanten av en av sliparna på varvet F3, där det planeras en tvärställd stoppare.

Allt metallavfall sorteras och säljs till skrothandlare. Spillolja samlas i en tank och levereras til IRF (offentligt bolag) (Figur 49). I fall av större mängder oljeavfall hämtar IRF en speciell tank till varvet. Inlämning av oljeavfall är gratis, eftersom en avgift har lagts på oljeprodukter som används för detta ändamål.

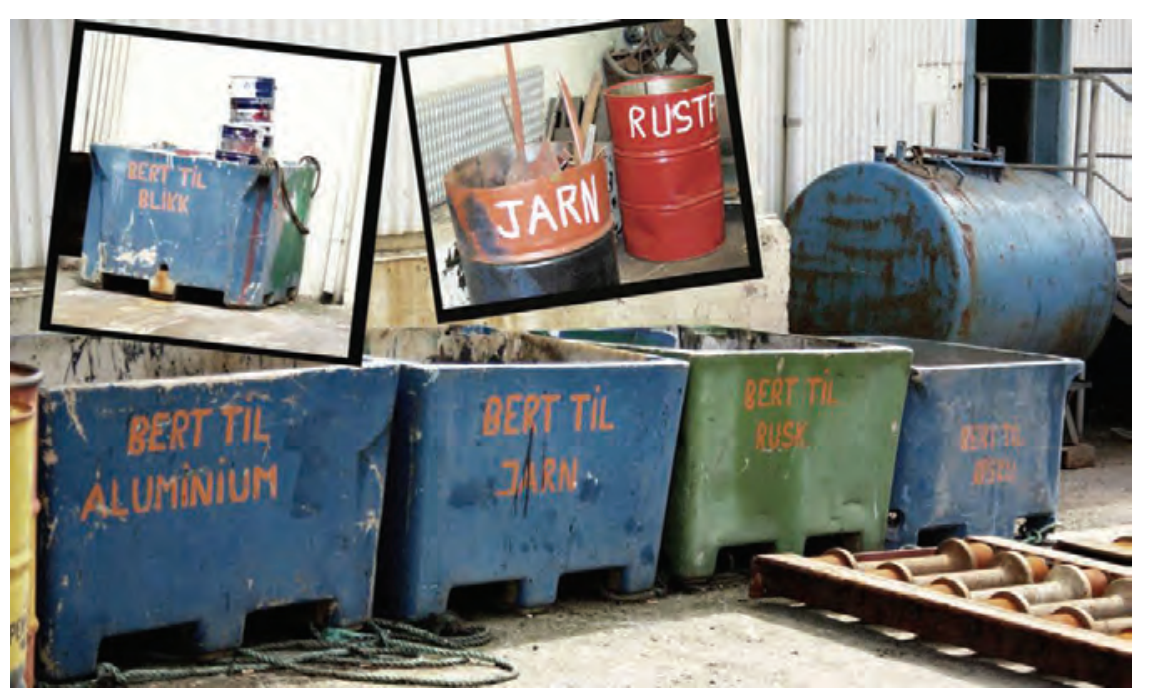

Figur 49. Containrar för uppsamling av sorterad metall, samt tank för oljeavfall.

Företagets representant föreföll att ha en "sund” inställning till ordning och till miljö. Detta tycktes i någon mån vara omsatt i praktisk handling; arbetsplatsen framstod som städad, och naturmiljön i närheten var vid en ytlig inspektion opåverkad av synliga avfallsprodukter. 


\section{Sammandrag, småvarv i Norden}

\subsection{Sammandrag, småvarv i Norge}

Med ett undantag var de besökta småvarven placerade så att det var en god omsättning på vattenmassorna, och vid dem var det inte möjligt att se effekter av lokal förorening på den biologiska miljön.

Kunskapsnivån om farliga ämnen var låg hos företagsägarna. De litar på att ämnenas producenter/leverantörer bara säljer sådant som är godkänt. Kunskapen om miljökonsekvenser är således också liten, även om man är medveten om att ämnen från sådan verksamhet kan vara skadliga. Det fanns lite kunskaper om hur farligt avfall hanterades efter tömning/leverans, och ett företag hade mycket skräp liggande runt om på sitt område.

Märkning av avfallscontainrar och sortering av avfall var med ett undantag bra i förhållande till den aktivitet de olika företagen hade.

Ett av företagen (som låg i anslutning till en skyddad marina) hade en delvis funktionell spolplattform, men tvivelaktig övervakning/tömningsrutin av sedimenteringsbassängen. De övriga hade inga åtgärder eller planer på åtgärder för uppsamling av avfall från rengöring av båtar.

Två av företagen låg centralt placerade i samhällen, och hade huvudsakligen lokala kunder. Ett av företagen låg avsides från bebyggelsen och ett företag låg i ett industriområde i en stad. Det fanns tyvärr inte tid för att utföra undersökningar bland grannarna för att kartlägga deras attityder till verksamheten.

\subsection{Sammandrag, småvarv på Åland.}

Farvattnen runt Åland är speciellt sårbara (brackvatten, dålig vattenomsättning, höga nivåer av miljögifter) jämfört med farvattnen längs den norska kusten och runt Färöarna. Detta är förmodligen förklaringen till att det läggs större fokus på verksamheten kring båtar och båtunderhåll i detta område.

Kunskapsnivån om farliga ämnen och deras effekter var moderat hos varvsägarna, medan de verkade ha bra kännedom om regelverket. Kunskapen om miljökonsekvenser är också liten, även om man är medveten om att ämnen från sådan verksamhet kan vara skadliga.

Bara ett av tre besökta företag hade system för avfallshantering och detta verkade fungera mycket bra. Samma företag hade planer på att in- 
stallera en anläggning för bottentvätt av båtar i havet, och hade samtidigt ett mycket rimligt erbjudande för upptag/bottentvätt som kan konkurrera med priset på kemisk bottenbehandling av båtar.

Inget av företagen hade spolplattform med möjlighet till uppsamling av avfall, och inte heller planer på att inrätta en sådan.

Den stora skillnaden mellan det "bästa" och det "sämsta" företaget tyder dock på att det inte utövas någon sträng kontroll av verksamheten. Ett av de två största företagen som besöktes var moderniserat och framtidsinriktat, och föreföll att ha en relativt god miljöprofil, medan det andra inte verkade använda resurser på varken utrustning, byggnader eller miljöåtgärder.

Ett av företagen låg centralt placerat $\mathrm{i}$ en stad med en campingplats som närmaste granne. De två andra låg relativt isolerade från annan bebyggelse. Det fanns tyvärr inte tid för att utföra undersökningar bland grannarna för att kartlägga deras attityder till verksamheten.

\subsection{Sammandrag, små skeppsvarv på Färöarna}

Färöarna omges av hav på alla sidor och har ett fjordlandskap som kan påminna om norska förhållanden. Detta i förening med det låga invånarantalet kan vara förklaringen till att det inte finns ett så starkt fokus på den marina miljön som till exempel på Åland.

Alla de besökta företagen var medvetna om att de släpper ut ämnen som kan vara skadliga. Vilka ämnen detta gäller och vilka skadeverkningar de har fanns det däremot liten kunskap om. Samtliga var intresserade av ett ökat samarbete med miljömyndigheterna för att få bättre insyn i miljöproblematik och för att anpassa driften på ett miljömässigt försvarbart sätt. En av de tre intervjuade verksamhetsägarna verkade känna regelverket väl.

Alla de tre besökta företagen hade system för avfallshantering och detta tycktes fungera mycket bra, med undantag för ett företag.

Inget av företagen hade spolplattform med möjlighet till uppsamling av avfall, men ett företag hade konkreta planer på åtgärder för att hindra att spolvattnet gick direkt ut i havet.

Samtliga företag hade varit verksamma på samma plats under en lång tid (> 50 år) och tycktes vara en naturlig och önskad del av lokalsamhället. Vi hade dock begränsat med tid för att samla in information från lokalbefolkningen runt företagen, så något säkert kan inte sägas om detta.

Ett av företagen efterlyste en certifieringsordning för att få slut på oseriös och miljöskadlig verksamhet inom branschen. 


\subsection{Allmänna iakttagelser}

\subsubsection{Driftsformer}

\section{Rälsgående båtvaggor}

Traditionella små slipar/varv med upptagning på räls disponerar ofta bara ett litet, överskådligt område, där de enkelt kan organisera ett system för sortering och deponering av avfall. På vissa slipar är rälsen placerad på ett fast underlag (betong), vilket kan förenkla uppsamling av fast avfall från spolning och rengöring. Andra slipar har rälsen direkt på den naturliga strandbanken, vilket försvårar uppsamling utan att relativt kostsamma åtgärder genomförs. Driftsformen begränsar antalet båtar per tidsenhet, och risken för förorening korrelerar starkt med antalet båtar som behandlas.

\section{Upptagning med mobila enheter}

Det är allt vanligare att båtupptagning sker med mobila enheter, som är oberoende av traditionell uppdragning från vattnet till land. För att uppnå kontroll av föroreningar från underhåll av båtar är det viktigt att fokus när det gäller information om miljömedveten inställning till båtskötsel samt eventuell kontroll och föreskrifter från miljöskyddsmyndigheternas sida också riktas mot sådana verksamheter. Många ägare till fritidsbåtar under 40 fot köper service och underhåll av företag som driver service, båtuppläggning och förvaring i kombination med en småbåtshamn. Båtarna lyfts upp av en flyttbar kran, eller i vaggor på hjul som dras av en truck, för att därefter placeras på ramper över ett stort område. Verksamheten kräver ingen stor bemanning i förhållande till antalet båtar, eftersom en stor del av arbetet utförs av båtägarna. Båtar som lyfts upp ur vattnet placeras runt om på stora områden som oftast ligger på naturgrund och är planerade närmast som parkeringsområde. Sådana driftsformer innebär att det till stor del är båtägarna som utför tvätt, målning och annan service. Detta ökar risken för att bristande kontroll från verksamhetsägarens sida leder till att stora områden blir mottagare av olika typer av miljöfarligt avfall från båtarna. Ofta kan det vara lång väg till spolplattformen eller till märkta containrar för avfall, där sådana alls finns.

Planläggningsmyndigheterna i Norge sätter inga speciella begränsningar för användning av områden godkända för industriändamål (annat än exempelvis tidsbegränsningar), och förutsätter att brukarna följer allmänna lagar och förordningar. Det kan tänkas att det borde finnas speciella krav förknippade med sådana användningstillstånd.

När en båt på land inte upptar kostsamma områden/redskap (som en rälsgående vagga), blir båtar ofta övergivna/lämnade som skräp och utgör därmed miljöproblem. Här kunde man utnyttja erfarenheter från hantering av övergivna bilvrak, där ägaren alltid kan ställas till svars. Detta förutsätter en heltäckande registrering och märkning av alla båtar, något som kan ligga lite längre fram i tiden. 


\subsubsection{Kunskap}

Generellt kan intrycken från de tre områdena sammanfattas enligt följande:

- Företagen hade lite kunskap om miljöskadliga ämnen.

- De flesta ville driva sin verksamhet så miljövänligt som möjligt, förutsatt att kostnaderna för detta inte blev för höga. Några hade klara uppfattningar om vad som krävdes för miljövänlig drift, medan andra inte hade någon uppfattning om vad som behövdes för miljövänlig verksamhet.

- De allra flesta var osäkra på vilka de gällande regelverken var.

Samtliga personer som vi har intervjuat hade liten kunskap om vilka ämnen (kemiska beteckningar) som är miljöskadliga eller förbjudna att användas i bottenfärg. Alla de vi frågade litade på att leverantören/butiken/importören garanterade att ämnena som de sålde var tillåtna. Alla kände till att varv hade varit källor till miljögifter, men var osäkra på om detta fortfarande är fallet i dag.

Orsaken till att kunskaperna om regelverk för utsläpp och hantering av farligt avfall är dåliga beror troligen på en kombination av företagens uppfattning om vem som är ansvarig för att sätta sig in i regelverk (dvs. företagets eget ansvar) och att regelverken är svårtillgängliga. Många företag drivs enligt gamla traditioner därför att de inte har fått krav om något annat, och de tycks därför anse att allt är i sin ordning. De förstår inte eller har inte tänkt över att företaget bär ansvar för att sätta sig in i gällande lagar och föreskrifter och för att följa dessa. Dessutom är vår erfarenhet att regelverket delvis är svårtillgängligt, även om mycket i dag finns på internet. Alla varvsägare använder inte aktivt webbaserade tjänster.

Med ett undantag hade ingen bra kännedom om regelverket för användning av kemikalier, och för deponering av avfall från verksamheten. I den grad företagen hade bra rutiner för avfallshantering tycktes det grunda sig på personligt sinne för ordning och intresse för arbetsmiljö och den omgivande naturen snarare än på att företagen följde regelverk eller föreskrifter från myndigheterna. Företag både i Norge och på Färöarna efterlyste bättre information från och ökad dialog med miljömyndigheterna. Bara ett av de besökta företagen (på Åland) tycktes vara helt negativt både till miljövänlig drift och i sitt förhållande till miljömyndigheterna.

\subsubsection{Attityder}

De flesta av företagen/intervjuobjekten visade klart positiva attityder gentemot miljömässigt försvarlig verksamhet och till dialog med myndigheter. I några enstaka fall tog detta sig klart uttryck i välordnade arbetsplatser med goda rutiner för verksamheten och för deponering av avfall. I andra fall hade de goda intentionerna inte omsatts i praktiken. 
När det gäller utsläpp i havet så var det bara ett företag som hade vidtagit åtgärder för att hindra dessa. Sådana åtgärder är ofta svåra att genomföra och dessutom relativt kostnadskrävande, så även om det finns intentioner för miljövänlig drift är intrycket att de flesta företag väntar på krav från miljöskyddsmyndigheter innan de vidtar sådana åtgärder. 



\section{Rekommenderade åtgärder}

\subsection{Miljöskyddsmyndigheter}

Miljöskyddsmyndigheterna har endast i liten utsträckning följt upp småvarv. Många småvarv har långa traditioner och det visar sig att driften i liten grad har ändrats i takt med ny kunskap och nytt regelverk. Orsaken till detta är troligen att verksamhetsägarna i liten grad är medvetna om sitt eget ansvar för att sätta sig in i lagar och regler. En dialog med miljöskyddsmyndigheterna där ansvarsfördelningen preciseras skulle i många fall kunna resultera i förbättrade driftsrutiner. Uppföljningen av aktiviteterna som utförs av båtägare skulle i många fall kunna förbättras genom att medvetandegöra företagarna/ägarna till områden som utnyttjas till båtuppläggning och underhåll om ansvaret för förorenad mark. Förorenad mark är markägarnas problem och kostnaderna för sanering är vanligtvis höga.

Den allmänna uppfattningen bland varvsägare tycktes vara att regelverket är svårtillgängligt. För att informationen ska nå ut till denna grupp av företag bör det utarbetas enkelt, lättfattligt informationsmaterial. Ett exempel på sådant informationsmaterial är broschyren "Båtliv - en ren glädje” utarbetad av Nordiska ministerrådet som informationsmaterial till innehavare av fritidsbåtar. Utarbetandet av informationsmaterial måste dock följas upp så att det faktiskt når rätta användare. Informationsmaterial till varvsägare kan exempelvis finnas tillgängligt där bottenfärg och liknande säljs eller sändas till företagen som information från miljöskyddsmyndigheterna.

Kontroller från miljöskyddsmyndigheter kan sannolikt vara ett verktyg som kan bidra till att höja standarden vid vissa småvarv. Flera företag efterlyste uppföljning från miljöskyddsmyndigheterna, medan andra medgav att de inte kom sig för att genomföra ändringar förrän de fick krav om det. En del företag väljer "billiga” lösningar som inte är så miljövänliga om kontroll och uppföljning uteblir, och detta kan smitta av sig på grannföretag.

\subsection{Småvarv}

\section{Småvarv med rälsgående slipar}

Dessa varv hanterar ett fåtal båtar per tidsenhet, och utnyttjar ett begränsat område. Detta gör att de skulle lämpa sig väl för system för insamling av avfall från spolning, målning och oljebyte. Själva konstruktionen med en rälsbana, ofta placerad på naturgrund, kan dock göra det svårt att an- 
passa verksamheten för sådana uppsamlingssystem. Om rälsbanan är placerad på ett fast underlag (betong eller asfalt) kan det vara enklare att installera en anläggning för uppsamling och rening av spolvatten. Bara ett företag (varv F3) höll på att utreda möjligheterna för ett sådant system (Figur 48).

Rapporten "Miljöanpassat båtupptag - Reningsanläggning för alla hamnstorlekar" (Samuelsson, 2006), presenterar olika former för att samla och rena avfall (fasta ämnen och spolvatten), och presenterar också kostnadsprognoser för investering och drift av sådana anläggningar. I en principskiss delas processen i steg 1 och steg 2 (Figur 50). Steg 1 omfattar en tät plattform som sluttar mot en längsgående ränna i mitten, där spolvattnet fångas upp och leds till en slamavskiljare. En mycket stor del av det giftiga avfallet fångas upp av partiklar från påväxtorganismer och bottenfärg, och ett sådant steg 1 bör införas på alla båtupptagningsplatser. Steg 2 omfattar användning av filter och pumpar för rening av spolvatten, och rapporten rekommenderar att det införs inom ett år på anläggningar som tar upp fler än 250 båtar per år och hänvisar i övrigt till att lokala miljöförhållanden måste avgöra om detta är nödvändiga åtgärder.

Rapporten presenterar detaljritningar av "Vallda Sandøs spolplatta" med slamavskiljare och sandfilter (Figur 50). Den beräknas kosta cirka $1000 \mathrm{kr} / \mathrm{m}^{2}$ (SEK, 2006) om arbetet utförs av en anläggningsfirma. Rapporten presenterar också de ekonomiska förutsättningarna för att driva en sådan anläggning, och har kommit fram till ett antaget pris från 57 till 336 kronor (SEK, 2006) per båtupptagning för användning av reningsanläggningen, beroende på om bägge stegen i processen är tillgängliga och hur många båtar företaget tar upp per år (Tabell 2).

Tabell 2. Estimerad kostnad per båtuppläggning (SEK, 2006) för att kunna finansiera en anläggning för uppsamling och behandling av spolvatten. (Enligt Samuelsson, 2006).

\begin{tabular}{rrr}
\hline Antal båtarlår & Steg 1 & Steg 2 \\
\hline$>250$ & 57 & 125 \\
120 & 60 & 176 \\
50 & 94 & 188 \\
15 & 156 & 336 \\
\hline
\end{tabular}

Med de grundläggande investeringsbehoven för sådana anläggningar är det dock få småvarv som har möjlighet att realisera anläggningar utan ekonomiskt stöd. 


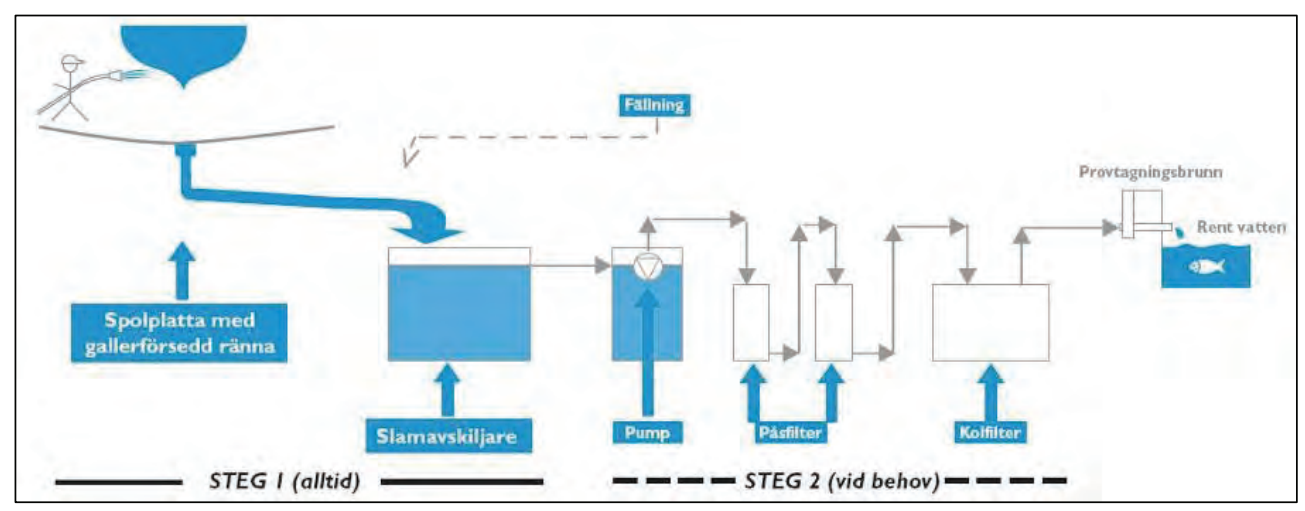

Figur 50. Principskiss för uppsamling och rening av spolvatten från båtrengöring (Från Samuelsson 2006).

\section{Upptagning med mobila enheter}

De allra flesta fritidsbåtar använder sig av upptagning med mobila kranar, vanligen på mer eller mindre organiserade båtuppläggningsplatser. Det stora antal båtar som varje år behandlas på dessa kräver att eventuella åtgärder också bör fokuseras på sådana driftsformer. Exempel på åtgärder för företag som hanterar många båtar per tidsenhet kan vara:

- krav på att alla båtar ska spolas på spolplattform med godkänt uppsamlingssystem för rester från spolning/bottenmålning (se Figur 50).

- utskick av lättförståeligt informationsmaterial till alla båtägare som vill använda sig av företagens tjänster eller område.

- att göra det möjligt att utveckla system för båttvätt i vattnet som alternativ till bottenbehandling av båtar (se vidare nedan).

- klargörande av ansvarsfördelningen mellan båtägare och verksamhetsägare vad gäller miljöavfall från båtar.

- skapa anordningar för sortering av avfall. God märkning är ett viktigt element för att sorteringskärlen ska användas.

\section{Alla}

En annan åtgärd som nämns i många utredningar om miljö och båt är båttvätt medan båten ligger i vattnet, ett "drive-in" system med roterande borstar likt det som används för bilar. Ett sådant system gör användningen av antifouling på båtar onödig, om båtbottnen tvättas flera gånger per säsong. Effekten, sammantaget med priset för en tvätt, är avgörande för om detta blir en populär metod. Dagens Nyheter (1/2-2008) skriver: "Senast genom en enkät som visar att 81 procent av de båtägare som använt båttvätten kommer att fortsätta och att 48 procent av de som tvättar sina båtar helt slutat att använda bottenfärg”. Britta Eklund, forskare vid institutionen för tillämpad miljövetenskap vid Stockholms universitet säger i samma artikel: "Som helhet är resultaten bra. En del är missnöjda med att tvätten inte gör ordentligt rent - framför allt i aktern. Men det kan bero på 
att de tvättar för sällan, i snitt 1,3 gånger per säsong mot tre som är rekommendationen”.

Det finns ett fåtal sådana båttvättar, men de utvecklas ständigt. Systemet har bland annat tagits i bruk för färjor som trafikerar farvattnen runt Åland. Det finns långt fler utmaningar i samband med sådana tekniska system i havsvatten än på land, och kanske det här finns behov av mer offentligt intresse och bistånd för att få fart på utvecklingen. 


\section{Slutsatser}

- Många företag uppgav att de önskar uppnå en miljövänlig drift, förutsatt att kostnaderna för detta inte blir så stora att företaget inte klarar av dem.

- Lagar och regelverk är svårtillgängliga (utspridda i många direktiv och föreskrifter).

- Företagen hade liten kunskap om vilka lagar och regler de borde följa. En allmän attityd var att de förväntade sig att kunskapen skulle komma till dem (sannolikt via de lokala miljöskyddsmyndigheterna). Ingen hade aktivt försökt att uppdatera sig.

- Kartläggningen av verksamheten vid småvarv i de tre undersökta regionerna (Troms, Åland, Färöarna) visade på många likheter mellan regionerna.

- Besöken avslöjade både bra och dåliga exempel på drift av småbåtsvarv från alla tre områden. Inget av de besökta företagen hade fungerande system för att kontrollera/rena spolvatten och avfall från rengöring och skrapning av båtar på land, även om ett företag hade etablerat en uppsamlingsbassäng för fast avfall från spolning.

- Inget företag hade anläggningar för tvätt av båtbottnar i havet.

- Rutinerna för hantering av farligt avfall varierade, från total ignorans till mycket goda rutiner, både för sortering och avhämtning.

- Det är viktigt att fokus också riktas mot servicehamnar som inte traditionellt har en slip (rälsgående båtvaggor), utan som har flyttbar lyftutrustning som gör att båtar enkelt kan lyftas och ”parkeras” var som helst i terrängen.

- Miljöskyddsmyndigheterna bör inleda en dialog med varvsägare/-ledare för ömsesidigt informationsutbyte.

- Miljöskyddsmyndigheterna kan bidra med att utarbeta och distribuera information om lagar och regler, samt om åtgärder som kan genomföras för att förbättra verksamheten.

- Kontroller kan vara ett nödvändigt verktyg för att höja standarden för miljövänlig drift av småbåtsvarv.

- Företag som sysslar med båtbehandling bör själva uppdatera sig på lagar och regler, samt på vilka åtgärder som kan genomföras i det egna företaget för att etablera rutiner och system för miljövänlig drift.

- Småvarv kan enkelt se till att inrätta system för sortering och hantering av farligt avfall. I alla de besökta regionerna fanns möjlighet till insamling av sådant avfall.

- Enkla system för uppsamling av fasta ämnen från spolvatten bör införas vid alla småvarv. Varv som hanterar många båtar per år bör dessutom inrätta system för rening av spolvattnet. 



\section{Referenser}

Båtliv, en ren glede. 2005. Informasjon til Båtfolk i Norden. Internet: www.norden.org/pub/sk/showpub.asp? pubnr=2005:746

SFT, 2005. Kartlegging av skipsverft. Steder hvor det kan ha oppstått forurensningsproblemer knyttet til bygging, underhåll og reparasjon av skip og offshoreinstallasjoner TA-

2044/2004 ISBN 82-7655-233-1

SFT, 2004. Forurensningssituasjonen i småbåthavner. Status, økologisk risiko, spredningsvurdering og

åtgärdersbehov (TA-2071/2004)

Per-Olof Samuelsson, Stenungsunds kommun, 2006. Miljöanpassat båtupptag - Reningsanläggning för alla hamnstorlekar. Projektrapport april 2006

Kemikalieinspeksjonen 2004. Kemiska ämnen i båtbottenfärger - en undersökning av koppar, zink och Irgarol 1051 runt Bullandö marina 2004. Rapport Nr 2/06. Link: www.kemi.se
HELCOM, 2004. The Fourth Baltic Sea Pollution Load Compilation (PLC-4). Balt. Sea Environ. Proc. No. 93 HELCOM 2008. www.HELCOM.fi Mørch, T. 2005. Harstad havn Miljøundersøkelser og risikovurdering av forurensede sedimenter og åtgärdersutredning. Sweco Grøner rapport nr. 128440-1.

Evenset, A. \& R. Palerud 2004. Miljøgifter i sediment fra Skattøra marina, september 2004. Akvaplan-niva rapport 414.3173.

Evenset, A., L.-H. Larsen, A. Kibsgaard \& A. Peftersen 2005. Forebygging og sanering av miljøgiftforurensning i Tromsø havneområde og Tromsøysund. Akvaplan-niva rapport 421.2508.03. SFT rapport TA 2084/2005. 68 p + appendix.Bilaga 1 Brev och frågeformulär 



\section{Bilaga 1 - Brev och Frågeformular}

Hej!

Jag hänvisar till vårt telefonsamtal strax före påsk om rutiner och miljöproblematik vid små skeppsvarv.

Här kommer lite kompletterande information och skiss till ett schema som visar vilka uppgifter jag hoppas få från företagsbesöken. Jag hoppas kunna arrangera ett besök hos er tidigast i slutet av vecka 14 eller senare. Tar telefonkontakt under nästa vecka.

Småvarv i Norden, informationsprojekt om verksamheten vid små båtvarv

En representant från Akvaplan-niva önskar göra ett besök vid Ert företag en dag i april-juni 2008 för att bidra med sin fackkunskap om miljöfrågor och för att studera hur företaget i praktiken löser miljöutmaningar i sitt arbete med underhåll av båtar.

\footnotetext{
Akvaplan-niva är en fristående, oavhängig konsultfirma som erbjuder tjänster inom akvakultur och marin- och sötvattensbiologi. Vi har i dag en internationell stab på cirka 60 biologer, ekologer, kemister och geologer. Våra internationellt ackrediterade kemiska och biologiska laboratorier erbjuder ett brett spektrum av högklassiga analyser. Akvaplan-niva har sitt huvudkontor och sina laboratorier i Polarmiljøsenteret i Tromsö, Norge.
}

Bakgrund:

På uppdrag av miljömyndigheter i Norden (Småsamfundsgruppen under Nordiska ministerrådet), genomför Akvaplan-niva en undersökning av hur små skeppsvarv i Norden driver sin verksamhet i förhållande till de miljökrav som samhället ställer på varje form av miljöförorening. Undersökningen, som finansieras av Nordiska ministerrådet, ska genomföras vid småvarv på Åland, i Norge och på Färöarna.

Med "samhällets miljökrav" menas här krav formulerade i internationella, nationella och kommunala regler.

Det gäller speciellt användningen av bottenfärg mot beväxning (antifouling), eftersom vissa medel kan ha skadeverkningar både på djur och människor om de inte hanteras på rätt sätt. 
Vilka är vi, och vad kan vi bidra med:

Vi representerar en firma med expertis inom miljösektorn och vi vill efter bästa förmåga bistå med information om principer, metoder och ämnen som lämpar sig för att hindra beväxning på båtar, och om hur skador på miljön kan undvikas eller begränsas.

Som en viktig del av projektet önskar vi göra ett besök på företaget och i lokalmiljön runt företaget under perioden april-juni, för att få en uppfattning om ifall det finns behov av mer information kring användning och hantering av farliga och okända ämnen. Vi önskar kartlägga goda exempel på rutiner som kan bidra till att trygga den lokala miljön runt företaget. Vi reserverar i princp en arbetsdag för kartläggning av företaget och lokalmiljön, och hoppas att ni då kan avsätta några timmar tillsammans med oss.

Mål:

Resultatet av kartläggningen ska utgöra en del av ett beslutsunderlag för uppdragsgivaren för att utveckla gemensam nordisk information till företag och båtägare. Målet med denna information ska bland annat vara att:

- säkerställa att verksamheten vid små skeppsvarv drivs på ett miljömässigt försvarbart sätt, till gagn för både djurliv och människors hälsa

- ge individuella företag och båtägare kunskap om aktuell miljöproblematik kring underhåll och användning av båt

- säkerställa att företag och båtägare ska bli medvetna om vilka regler och vilket ansvar de har enligt lokala, nationella och internationella regelverk.

Om det är något ni önskar få information om, svarar vi gärna på frågor.

Vi bifogar ett schema över frågor som visar vad vi hoppas få svar på under besöket.

Med vänlig hälsning,

För Akvaplan-niva AS 
Mål för fältarbetet

Schema för registrering av teknisk konstruktion av båtupptag

\begin{tabular}{l}
\hline Lyftsystem / antal \\
\hline Vagga på räls \\
Vagga på hjul \\
Kajkran \\
Kajkran körbar \\
Annat (torrdocka, tvätt vid kaj...) \\
\hline
\end{tabular}

\section{Företagets storlek:}

\begin{tabular}{|c|c|c|c|c|c|}
\hline \multirow[t]{2}{*}{ Båtstorlek (m/f) } & \multirow{2}{*}{$\begin{array}{l}\text { Antal båtar } \\
\text { per säsong }\end{array}$} & \multirow{2}{*}{$\begin{array}{l}\text { Behandlad } \\
\text { bottenareal-m }{ }^{2}\end{array}$} & \multicolumn{3}{|c|}{ Ange ungefärlig \%-andel för varje aktivitet } \\
\hline & & & Spolning & $\begin{array}{l}\text { Spolning och } \\
\text { bottenmålning }\end{array}$ & $\begin{array}{l}\text { Spolning, skrap- } \\
\text { ning och målning }\end{array}$ \\
\hline \multicolumn{6}{|l|}{$<6 / 20$} \\
\hline \multicolumn{6}{|l|}{$6-10 / 20-33$} \\
\hline \multicolumn{6}{|l|}{$10-15 / 33-50$} \\
\hline $15-25 / 50-83$ & & & & & \\
\hline
\end{tabular}

\section{Schema för översikt över kemikalieanvändning}

\begin{tabular}{|c|c|c|c|c|}
\hline Namn, 3 vanligaste: & Fabrikat & Verksamt ämne & Relativ användning (\%) & $\begin{array}{l}\text { Estimerad } \\
\text { årsförbrukning }\end{array}$ \\
\hline \multicolumn{5}{|l|}{ Tvättmedel } \\
\hline \multicolumn{5}{|c|}{ Primer, bottenbehandling } \\
\hline \multicolumn{5}{|l|}{ Bottenfärg } \\
\hline Andra kemikalier & & & & \\
\hline
\end{tabular}

Schema för rutiner:

Arbetsrutiner

\begin{tabular}{lllll}
\hline & $\begin{array}{l}\text { Med plattform/ } \\
\text { uppsamling }\end{array}$ & $\begin{array}{l}\text { Med uppsam- } \\
\text { ling och } \\
\text { filtrering }\end{array}$ & $\begin{array}{l}\text { Utan uppsam- } \\
\text { ling, utsläpp i } \\
\text { havet }\end{array}$ & $\begin{array}{l}\text { Utan uppsam- } \\
\text { ling, utsläpp i } \\
\text { marken }\end{array}$ \\
\hline $\begin{array}{l}\text { Slipning med dammsugare } \\
\text { Slipning, utan dammsugare }\end{array}$ & & & \\
Skrapning & & & \\
Högtryckspolning & & & \\
Sandblästring \\
Annat:
\end{tabular}

Förvaring

Avfallshantering

\begin{tabular}{llllll}
\hline Typ av avfall: & $\begin{array}{l}\text { Egen } \\
\text { deponi }\end{array}$ & $\begin{array}{l}\text { Andel i regelmässigt } \\
\text { märkt container }\end{array}$ & $\begin{array}{l}\text { Rutiner för } \\
\text { tömning }\end{array}$ & $\begin{array}{l}\text { Andel på } \\
\text { havet }\end{array}$ & $\begin{array}{l}\text { Andel, annat } \\
\text { (beskriv) }\end{array}$ \\
\hline $\begin{array}{l}\text { Sand } \\
\text { Skrapavfall }\end{array}$ & & & \\
Spolvatten & & \\
Färgrester & & \\
Oljeprodukter & & \\
Lösningsmedel & & \\
Annat & & \\
\hline
\end{tabular}


Schema för frågor om företagets miljöhänsyn

- för företaget och för det omgivande samhället

\section{För företaget:}

Känner du till vilka regler som gäller för utsläpp av farliga eller okända ämnen?

Nej Några Ja

Vet du vilka ämnen som är förbjudna i bottenfärger?

Vet du varför vissa ämnen är förbjudna i bottenfärger?

Tror du att verksamheten leder till att farliga eller okända ämnen släpps ut i naturen?

Har företaget vidtagit åtgärder för att begränsa utsläpp vid bottenbehandling av båtar?

Har företaget planerat åtgärder för att begränsa utsläpp vid bottenbehandling av båtar?

Har företaget fått offentliga krav och villkor angående utsläpp?

För det omgivande samhället:

Frågorna nedan gäller utsläpp från underhåll/putsning av båtar.

Tror du att småvarv släpper ut farliga eller okända ämnen i naturen?

Tror du att det är viktigt för din hälsa att företaget inte släpper ut farliga eller okända ämnen i naturen?

Tror du att offentliga regler gör det olagligt att släppa ut farliga eller okända ämnen i naturen?

Tror du att varvet har ansvaret för eventuella utsläpp vid underhållsarbete på båtar?

Tror du att båtägaren har ansvaret för eventuella utsläpp vid underhållsarbete på båtar?

\section{Historik}

Lite om hur länge varvet har varit i drift och hur verksamheten har ändrat sig (volym och typ av arbetsuppdrag 
Bilaga 2

- Sammanställning av observationerna 


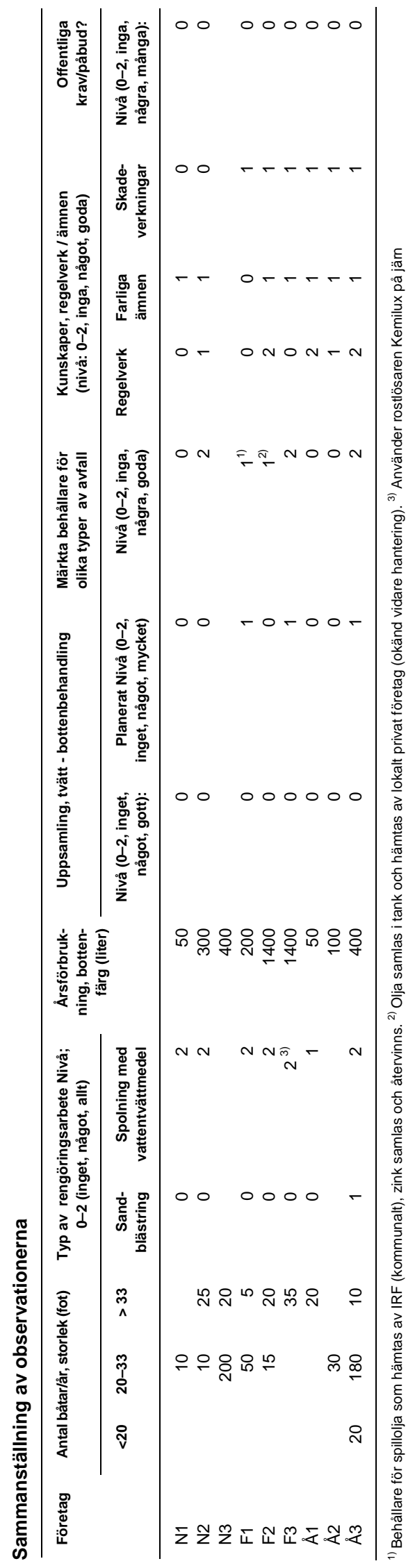

